REVISTA DE DERECHO UNED, NÚM. 17, 2015

\title{
LA CAPACIDAD INFRACTORA DE LAS ENTIDADES CARENTES DE PERSONALIDAD JURÍDICA EN EL ORDENAMIENTO JURÍDICO TRIBUTARIO Y RESPONSABILIDAD INFRACTORA EN SUPUESTOS DE CONCURRENCIA DE INFRACTORES
}

\author{
OFFENDING CAPACITY OF NON-CORPORATE ENTITIES \\ RECOGNICED UNDER GENERAL TAX LAW AND INFRINGING \\ RESPONSIBILITY IN CASES OF OFFENDERS CONCURRENCE
}

IVÁN PÉREZ JORDÁ

Funcionario de Administración Local con habilitación de carácter nacional. Doctor en Derecho Financiero y Tributario

Resumen: Tras un conciso repaso del marco legislativo español y análisis de los tipos de sujetos infractores, analizamos los supuestos en los que los entes carentes de personalidad jurídica propia pueden ser sancionados de modo independiente a sus socios, y terminamos el artículo exponiendo un análisis crítico a los supuestos de concurrencia de responsables y su relación con la responsabilidad solidaria o subsidiaria en el pago de sanciones tributarias.

Palabras clave: entidades carentes de personalidad jurídica, responsables solidarios del contribuyente, responsabilidad subsidiaria.

Abstract: After a concise revision of the Spanish legislative frame and analysis of the types of inobservant subjects, we analyze the assumptions in which the non legal personality collectives can be sanctioned in an independent way to its associates, and finish the article exhibiting a critical analysis to the offenders concurrence and its relation with assumptions of united or subsidiary responsibility in the payment of tributary sanctions. 
Key words: non legal personality collectives, co-joint liability of the taxpayer, subsidiary liability.

Sumario: 1. Los sujetos infractores en el ordenamiento jurídico tributario. Configuración general. 2. Capacidad infractora de las entidades carentes de personalidad jurídica. 3. La concurrencia de varios sujetos infractores. Consideraciones.

\section{LOS SUJETOS INFRACTORES EN EL ORDENAMIENTO JURÍDICO TRIBUTARIO. CONFIGURACIÓN GENERAL}

La vigente Ley General Tributaria ${ }^{1}$ dedica dos artículos, que integran la sección 1. ${ }^{a}$ del capítulo II del título IV de la misma, a la regulación de los que denomina «sujetos responsables ${ }^{2}$ de las infracciones y sanciones tributarias». Concretamente, el artículo 181 se ocupa de la regulación de los sujetos infractores, mientras que el artículo 182 se refiere a otros sujetos, a quienes por designio de la ley se les van a extender las consecuencias del incumplimiento del autor principal, concretamente, los responsables ${ }^{3}$ y los sucesores de las sanciones tributarias, por lo que la extinción de la responsabilidad infractora del primero les podrá servir en su beneficio.

Centrando la atención en el primero de los preceptos mencionados, su apartado 1 mantiene la misma estructura que tenía el apartado 3 del artículo 77 de la LGT de $1963^{4}$, de forma que, primeramente, se lleva a cabo una descripción general de los sujetos infractores, para después ofrecer una lista meramente ejemplificativa de quienes pueden tener tal condición. La definición que de los sujetos infractores, respecto de quienes se producirá la extinción de la responsabilidad dimanante de la infracción tributaria, nos la proporciona el primer párrafo del artículo 181.1 LGT, que mantiene los mismos términos en que se pronunciaba la regulación precedente, y en este sentido cabe señalar que, al igual que sucedía entonces, la cuestión más relevante que la misma suscita es la de la referencia, que en ella se contiene, a

\footnotetext{
${ }^{1}$ Ley 58/2003, de 17 de diciembre, General Tributaria.

${ }^{2}$ La Ley General Tributaria excluye la posibilidad de la figura del responsable del responsable (STS 07.03.2014, FJ 3).

${ }^{3}$ Aunque dicha responsabilidad - que debe ser siempre objeto de interpretación restrictiva- se refiere únicamente a la de las consecuencias económicas o pecuniarias, y no a las no pecuniarias a que refiere el art. 186 LGT, que nunca serían derivables, al ser accesorias de la infracción y no propiamente de la sanción tributaria, a más de por no expresarlo así la LGT.

${ }^{4}$ Ley 230/1963, de 28 de diciembre, General Tributaria.
} 
las personas jurídicas y entidades sin personalidad jurídica como posibles sujetos infractores. Ello es así porque, como era sabido, en el Derecho Penal patrio, siguiendo la que constituía la pauta general de los sistemas continentales, regía la máxima societas delinquere non potest ${ }^{5}$ en atención, básicamente, a la ausencia de capacidad de acción penal en las personas jurídicas -dado que se entendía carecían de una voluntad propia-, capacidad de culpabilidad -cuyo juicio de culpabilidad debería necesariamente realizarse en relación con las personas a través de las cuales actuaba la entidad-y capacidad de pena -y pena a aplicar a un ente colectivo nada tenía que ver con los conceptos de expiación, retribución, reeducación o intimidación ${ }^{6}-$, de modo que, al consagrar el Derecho sancionador tributario y el administrativo en general, justamente el criterio opuesto, produjo, no ya un matiz, sino una auténtica excepción a la proclamada transposición de principios del orden penal al orden sancionador ${ }^{7}$, excepción inexistente tras la

\footnotetext{
${ }^{5}$ La postura es la contraria en los sistemas anglosajones, y también en algunos ordenamientos europeos por influencia de aquéllos -Francia, Holanda y Bélgica-, admitiéndose en dichos sistemas la responsabilidad penal de las personas jurídicas. En cualquier caso, pese a que, como se ha dicho, los sistemas continental y anglosajón mantienen en principio posturas opuestas sobre esta cuestión, una observación práctica del fenómeno conduce al resultado de que, a la postre, en ambas sistemas las personas jurídicas sufren idénticas sanciones: aquellas que por su naturaleza les resultan aplicables a los entes colectivos. Puede verse al respecto BAJO FERNÁNDEZ, M. y BACIGALUPO ZAPATER, E. (2001): Derecho Penal Económico, Ceura, Madrid, págs. 115 y ss.

${ }^{6}$ ARAGONÉS BELTRÁN, E. (1995): La Reforma de la Ley General Tributaria, Cedecs, Barcelona, pág. 117; «la culpa, por su propia naturaleza, se encuentra reservada al entendimiento humano: es cosa en que sólo el hombre puede incurrir», GUERRA REGUERA, M.(1995): Condonación de sanciones tributarias y principios constitucionales, Marcial Pons, Madrid, pág. 33; sólo las personas físicas disponen «de una voluntad propia que permita el juicio de reproche implícito en toda sanción» CASADO OLLERO, G; FALCÓN y TELLA, R; LOZANO SERRANO, C y SIMÓN ACOSTA, E. (1991): Cuestiones Tributarias prácticas, La Ley, Madrid, pág. 693; SAINZ DE BUJANDA, F.(1967): «La capacidad jurídica de los entes colectivos no dotados de personalidad», Hacienda y Derecho, vol. V, IEF, Madrid, pág. 605; la persona jurídica «nunca conseguirá superar la gran limitación que supone carecer del soporte psicológico indispensable para fundamentar el juicio de reproche implícito en el concepto de culpabilidad»; GARCÍA DE ENTERRÍA, E.(1976): «El problema jurídico de las sanciones administrativas», REDA, Civitas, núm.10, pág. 413; las personas jurídicas están dotadas «de una personalidad jurídica propia e independiente de las personas físicas que la integran. Como tal persona jurídica, está dotada de órganos propios y asume, en el tráfico mercantil, sus propias obligaciones, distintas de los miembros físicos que la componen. En la misma línea, la responsabilidad de la Sociedad, es también distinta de la de sus miembros, tal y como previene la legislación sobre Sociedades Anónimas» (STSJ de Cataluña de 21 de marzo de 1997); También en la STSJ de Asturias de 14 de enero y de 29 de julio de 1998. "siendo obvia la capacidad de infringir por parte de las personas jurídicas» (RTEAC de 12 de mayo de 1998); he aquí uno de los matices (STSJ de Asturias de 14 de enero y de 29 de julio de 1998).

${ }^{7}$ En este sentido, NIETO GARCÍA, A.(1994): Derecho Administrativo Sancionador, Tecnos, Madrid, págs. 352 y 353. Téngase en cuenta, no obstante, que el Tribunal Constitucional, en su Sentencia 246/1991, de 19 de diciembre, ha sostenido que el reconocimien-
} 
LO $5 / 2010^{8}$, donde las personas jurídicas son sujetos de derecho penal, teniendo, hoy, capacidad de pena.

Ciertamente, no parece consustancial a la naturaleza de las cosas que, el cambio en la gravedad del hecho -pasando de la infracción al delito o viceversa-, deba comportar el cambio en la idoneidad del sujeto infractor ${ }^{9}$. No obstante, el legislador ha considerado oportuno seguir manteniendo en la actual LGT el criterio precedente sobre esta cuestión, acogiendo de este modo la opinión sustentada en el Informe para la reforma de la Ley General Tributaria, en el que, tras analizar las ventajas y los inconvenientes de las diversas alternativas posibles de responsabilidad en la comisión de infracciones tributarias, se terminó optando por la regla de la responsabilidad infractora de carácter directo de las personas jurídicas y entidades ${ }^{10}$, frente a otras opciones, como podría ser hacer recaer la autoría de la infracción tributaria en los titulares de los órganos decisorios de la entidad, sin perjuicio de imponer a ésta consecuencias de diversa índole, pese a que este tipo de soluciones se considera preferible por algún autor ${ }^{11}, y$, además, han tenido acogida en otros ordenamientos de nuestro entorno ${ }^{12}$.

to por el Derecho Administrativo de capacidad infractora a las personas jurídicas no significa en absoluto que para el caso de las infracciones administrativas por ellas cometidas «se haya suprimido el elemento subjetivo de la culpa, sino simplemente que ese principio se ha de aplicar necesariamente de forma distinta a como se hace respecto de las personas físicas». De esta jurisprudencia se hizo eco el Tribunal Supremo, en Sentencias inmediatamente consecutivas, de 20 de mayo de 1992, de 30 de noviembre de 1992; y de 10 de diciembre de 1992, entre otras.

${ }^{8}$ Ley Orgánica 5/2010, de 22 de junio, por la que se modifica la Ley Orgánica 10/1995, de 23 de noviembre, del Código Penal.

${ }^{9}$ Así lo afirma GRAUER GODOY, A.(2004): «Bases para un modelo de imputación penal de las personas jurídicas en Derecho español», Diario La Ley, núm. 6136, 26 de noviembre de 2004; MARTÍN QUERALT, J; LOZANO SERRANO, C; TEJERIZO LÓPEZ, J. y CASADO OLLERO, G.(2007): Curso de Derecho Financiero y Tributario, Tecnos, Madrid, pág. 217.

${ }^{10}$ En efecto, en el Informe se concluye que «se propone que exista un único infractor, la persona jurídica, y que los administradores sean responsables subsidiarios de las obligaciones tributarias y la sanción", Informe de la Comisión para el estudio y propuestas de medidas para la reforma de la Ley General Tributaria (2001), IEF, Madrid, pág. 179.

${ }^{11}$ Así, PÉREZ ROYO, F.(1986): Los delitos y las infracciones en materia tributaria, IEF, Madrid, págs. 282 y 283: e, igualmente, FUSTER ASENCIO, C. (2001): El procedimiento sancionador tributario, Aranzadi, Navarra, págs. 106 a 108.

${ }^{12}$ Ese es el caso del sistema italiano, donde el Decreto Legislativo núm. 472, de 18 de diciembre de 1997, ha implantado en materia de infracciones tributarias la máxima societas delinquere non potest, de modo que, sólo la persona física, de conformidad con el artículo 2.2 de la citada norma, puede ser considerada autor directo de la infracción. Al respecto, puede consultarse SANMARTINO (2001): «Principi, diritti e garazie costituzionali nel sistema tributario sanzionatorio. L'esperienza italiana», Principios, derechos y garantías constitucionales del régimen sancionador tributario, vol. I, Documento núm. 
No obstante, como se ha visto, una vez proclamada por la LGT la capacidad infractora tributaria -y, la penal por el Código Penal ${ }^{13}$ - de las personas jurídicas, y la posibilidad de hacer recaer sobre ellas las correspondientes sanciones en cuanto autores directos del ilícito, el artículo 43.1, en su letra a) LGT, establece la responsabilidad subsidiaria ${ }^{14}$ de los administradores ${ }^{15}$ de las mismas por las sanciones impuestas, cuando con su comportamiento activo u omisivo hayan determinado la comisión del tipo, lo que a juicio de un importante sector doctrinal ${ }^{16}$ constituye, al igual que otros supuestos de transmisión de la sanción al responsable que

19/01, Instituto de Estudios Fiscales, pág. 162; y también LUPI (1998): Diritto Tributario. Parte Generale, Giuffrè, Milán, pág. 261.

${ }^{13}$ Ley Orgánica 10/1995, de 23 de noviembre, del Código Penal.

${ }^{14}$ Cuya diferencia, más aparente que real, entendemos que debe de provenir de que en el supuesto del art. 42.1.a) LGT -solidaria- se refiere a supuestos de participación directa e inmediata, y el caso del art. 43.1.a) LGT -subsidiaria- se refiere a participación mediata (preventiva o de vigilancia). En ningún caso, ello debe dar lugar a pensar que se exijan grados diferentes de culpa en la actuación en que se basa cada presupuesto de hecho. En todo caso, recordemos que tratar de justificar la imposición de sanciones a la persona jurídica, defendiendo que son éstas, y no las personas físicas a través de las que actúan, las que han cometido la infracción, impide, después, considerar justificada la responsabilidad de los administradores sobre las sanciones impuestas a la sociedad, en cuanto que ellos han realizado materialmente la acción típica y han actuado culpablemente, precisamente, porque previamente se ha entendido que su acción y voluntad es la acción y voluntad de la sociedad. No parece lógico defender primero que la persona jurídica, y no las personas físicas que integran sus órganos, comete la infracción tributaria, y después, considerar justificada una imputación subsidiaria de esa misma sanción a las personas físicas que actuaron en nombre de la sociedad.

${ }^{15}$ Puede dar lugar al nacimiento de la responsabilidad tributaria (subsidiaria) de los administradores únicamente en los tres supuestos previstos en dicho precepto (art. 43.1.a LGT). Habrá que tener muy en cuenta la interpretación extensiva o restrictiva que se les de a vocablos, -nexos causales y presupuesto de hecho de la responsabilidad subsidiaria-, como «cometido»-por acción u omisión-, «actos o acuerdos»- y su tipología y órgano emisor-, «acto necesario»-, o "consentimiento»-expreso o tácito. Entendemos que estas circunstancias excluirían la responsabilidad subsidiaria, y no sólo la sanción, e cuando se trate de una decisión colectiva, siempre que los administradores que hubieran salvado su voto o no hubieran asistido a la reunión en que se tomó la misma, pese a que el art. 179.2 LGT pudiera dar a entender que sólo les excluye la sanción tributaria y no la derivación de la responsabilidad.

${ }^{16}$ Matizadamente, la opinión de Herrera Molina parece ser que la responsabilidad tributaria prevista en el artículo 38.1 de la LGT, que no se extenderá a las sanciones tributarias impuestas al deudor principal, surgirá: en primer lugar, «cuando la infracción principal haya sido causada mediante una infracción instrumental del responsable tipificada autónomamente»; en segundo lugar, «en las hipótesis de mera complicidad (en el sentido del Código Penal); y, dudosamente, «en el caso de una colaboración puramente material en la infracción». HERRERA MOLINA, P. M. (1997): «Coautoría y participación en las infracciones tributarias» en la obra colectiva, Sujetos pasivos y responsables tributarios. XVII Jornadas Latinoamericanas de Derecho Tributario, Marcial Pons, Madrid, págs. 704 y ss. 
administre de facto o de derecho, una tergiversación de lo que debe ser, en esencia, la figura de la responsabilidad tributaria, en cuanto garantía ${ }^{17}$ del crédito tributario ${ }^{18}$, del cual, como es sabido, no forma parte la sanción ${ }^{19}$-consecuencia económica de la infracción tributaria cometida ${ }^{20}-$.

${ }^{17}$ La existencia de dolo o, al menos, simple negligencia en la conducta del administrador sería, pues, una exigencia directa de la aplicación del principio de culpabilidad -nulla poena sine culpa- sobre la propia responsabilidad tributaria que se impone al administrado, la cual, en relación con la sanción tributaria, se encontraría al servicio de la potestad sancionadora de la Administración. A pesar de que la responsabilidad tributaria sobre los demás elementos de la deuda tributaria, distintos de la sanción tributaria impuesta a la sociedad, no tendría naturaleza sancionadora, dicha responsabilidad tributaria, por ser una consecuencia jurídica accesoria de la responsabilidad sobre la sanción, seguiría el mismo régimen jurídico de esta última, de ahí que solamente podría exigirse al administrador el pago del tributo correspondiente a la sociedad cuando éste hubiera infringido culpablemente en nombre de ésta las obligaciones tributarias impuestas por el ordenamiento tributario. Serán pues responsables los administradores que por acción u omisión hayan promovido el obrar antijurídico de la entidad en los cuales deberá concurrir la misma culpabilidad, dolosa o culposa, imputable a la entidad y constitutiva de infracción. En general, serían de aplicación la totalidad de principios jurídicos que deben informar el Derecho administrativo sancionador y, especialmente, el de presunción de inocencia. De esta manera, si se considera que al administrador se le sanciona por la autoría material de la infracción tributaria previamente imputada a la persona jurídica, hay que añadir, necesariamente, que la Administración será quien deba probar esa autoría material del infractor. Por otra parte, esa extensión de los principios del Derecho administrativo sancionador al ámbito de la responsabilidad tributaria, motivada por considerar que ésta cumple una función sancionadora, permite explicar mejor porqué no serán declarados responsables tributarios los administradores que no hayan intervenido en la adopción del acuerdo infractor, bien por no estar presentes, bien por haber salvado su voto.

${ }^{18}$ Aunque, como indica HERRERA MOLINA en su Teoría de la Solidaridad en la sanción, y HERRERO MADARIAGA, «no hay tal responsabilidad, sino una titularidad común en la comisión de la infracción que provoca una cotitularidad solidaria pasiva en la obligación pecuniaria en que se traduce la sanción». Los defensores de esta teoría apuntan que la extensión de las consecuencias jurídicas de la infracción al partícipe en el hecho tipificado como tal no supondría una vulneración del principio de personalidad de la pena, derivado del artículo 25.1 de la C. E., puesto que el partícipe no es un sujeto extraño al hecho constitutivo de infracción tributaria (el partícipe no interviene en el hecho ajeno), y, por tanto, la responsabilidad en la sanción constituye una consecuencia jurídica directa de la realización de la infracción tributaria sancionada a través de aquélla, como así pareció aceptarlo el Tribunal Constitucional en la Sentencia 76/1990.

${ }^{19}$ FUSTER ASENCIO, C.(2001), pág. 116; y ÁLVAREZ MARTÍNEZ, J. y otros(Dir. SIMÓN ACOSTA, E) [2004]: La responsabilidad de los administradores de las personas jurídicas, en la nueva Ley General Tributaria, Asociación Española de Asesores Fiscales y Thomson-Aranzadi, Navarra, pág. 70. Resulta aleccionador al respecto que el Tribunal Superior de Justicia de Castilla-La Mancha, refiriéndose a este supuesto de responsabilidad subsidiaria en la regulación precedente, dijo en su Sentencia de 20 de mayo de 2000 que «hay que reconocer que dicha responsabilidad no sólo cumple la función de garantía que le corresponde, sino también la finalidad represiva e intimidatoria que caracteriza las sanciones de tipo penal».

${ }^{20}$ No habiéndose impuesto sanción alguna a la persona jurídica que representan, los administradores no responderán tributariamente. 


\section{De este modo artículo 181.1 LGT ejemplificativamente ${ }^{21}$ nos informa que entre otros ${ }^{22}$, serán sujetos infractores ${ }^{23}$ los siguientes: a) los contribu-}

${ }^{21}$ De la relación no exhaustiva del artículo 35.2 LGT se omiten a los obligados a realizar pagos fraccionados, a los obligados a repercutir, a los obligados a soportar la repercusión, a los obligados a soportar los ingresos a cuenta, a los obligados a soportar la retención, los beneficiarios de supuestos de exención, devolución o bonificaciones tributarias, cuando no tengan la condición de sujetos pasivos, los responsables.. En cuanto a los sucesores de personas físicas, no resulta posible la transmisión de las sanciones ni infracciones (art. 39.1. ${ }^{\circ}$ in fine y $182.3 .^{\circ}$ LGT), mientras que para las personas jurídicas si resulta admisible en los términos establecidos en los arts. $182.3 .^{\circ} \mathrm{y}$ 40 LGT. MARTÍN QUERALT observa que «las obligaciones que tuviera el causante persona física- como responsable sólo se transmitirán a los herederos cuando ya se hubiera notificado el acto derivativo de responsabilidad con anterioridad al fallecimiento», sin embargo «el art. 40.5 precisa que las sanciones que pudieran proceder por las infracciones cometidas por las entidades extinguidas se exigirán a sus sucesores, en los términos de los apartados anteriores, hasta el límite del valor de la cuota de liquidación que les corresponda. Nuevamente cabe dudar del ajuste constitucional de este precepto, habida cuenta de que todos los socios o partícipes de la entidad extinguida, hubieran sido o no administradores, o hubieran o no participado en su gestión, tendrían que hacer frente a unas sanciones por infracciones con cuya comisión nada tuvieron que ver. Pese a que también el art. 182.2 LGT ratifica esta solución, nos parece que no puede prevalecer la eventual consideración de la sanción como deuda pecuniaria integrante del pasivo de la entidad frente a los principios constitucionales básicos del orden sancionador, el primero de los cuales es la concurrencia probada de la autoría y de la culpabilidad». Martín Queralt, J y otros, (2007), págs. 143 y 144; ¿Cuál es la utilidad de esta lista? La respuesta es: ninguna. Mejor dicho: la lista, tal como está redactada, desde su encabezamiento es en sí misma un disparate [Tal parece como si se pensara que el principio rector de la investigación tributaria fuera el siguiente: todo contribuyente es un defraudador. No conocemos aún los detalles, pero él, seguro que sí.] PÉREZ ROYO, F. (2009): Derecho Financiero y Tributario. Parte General, Civitas, Madrid, pág. 395.

${ }^{22}$ Dicha relación de sujetos infractores es inclusa, y tiene la única finalidad de ejemplificar los mismo, pues su consideración dependerá de que su conducta aparezca tipificada como tal, y, en definitiva la obligación, cuyo incumplimiento constituya la infracción, le incumba... Por ello más que señalar los sujetos infractores nos remite a la infracción tipificada y, en definitiva y dada su amplia tipificación, al incumplimiento de la obligación tributaria. SÁNCHEZ HUETE, M. A.(2007): Las infracciones en la nueva Ley General Tributaria, Marcial Pons, Madrid, pág. 55; En idéntico sentido FERREIRO LAPATZA, J. J.(2006): Curso de Derecho Financiero Español: Instituciones, Marcial Pons, Madrid, pág. 550.

${ }^{23}$ Los administrados, como sujetos pasivos de obligaciones y deberes tributarios, se encuentran en la situación de sujeción general que caracteriza la posición de todo ciudadano frente a la Administración, situación en modo alguno equiparable a la sujeción especial en que se encuentran determinados ciudadanos en virtud de la relación especial que les liga a la Administración, v.gr. funcionarios, concesionarios, etc...Son pues los ciudadanos, en cuanto están llamados a cumplimentar este deber y ocupar en las relaciones tributarias una situación pasiva, quienes pueden, incumpliendo los deberes y obligaciones que esta situación comporta, cometer una infracción tributaria. También la Administración puede infringir el ordenamiento tributario. Tales infracciones pueden originar la invalidez de los actos en que consistan,.. Naturalmente los funcionarios de la Administración financiera pueden ser igualmente sujetos infractores de una infracción de las normas tributarias FERREIRO LAPATZA, J. J.(2006), pág. 548. 


\section{yentes $^{24}$ y los sustitutos de los contribuyentes ${ }^{25}$, b) los retenedores ${ }^{26}$ y los}

${ }^{24}$ Recordemos que la situación jurídica del contribuyente es indisponible, y que se fija, siempre, a partir del hecho imponible. CALVO ORTEGA, R.(2010): Curso de Derecho Financiero. Derecho Tributario. Parte General, Civitas, Madrid, pág. 172-173.

${ }^{25}$ OCHOA destaca que la propia redacción puede inducir a error. Así cuando el tributo se exige exclusivamente mediante la figura del contribuyente, el cumplimiento de la obligación principal y de las formales que derivan de la realización del hecho imponible le incumbe exclusivamente a éste, por lo que en caso de incumplimiento el contribuyente será infractor. Por el contrario, cuando se exija mediante la dualidad de obligados tributarios (contribuyente y sustituto del contribuyente), el cumplimiento de la obligación principal y de las formales que derivan de la realización por el contribuyente del hecho imponible le incumbe no a éste sino al sustituto del contribuyente, por lo que en caso de incumplimiento, el sujeto infractor será exclusivamente el sustituto (art. 36.3 LGT), quedando exonerado el contribuyente de responsabilidad en caso del incumplimiento de las obligaciones tributarias por parte del sustituto. DÍEZ OCHOA, J. M.(2006): Derecho Tributario Sancionador. Comentarios y casos prácticos, CEF, Madrid, págs. 53 y 54; Tenemos la figura del sustituto del contribuyente en el ICIO, en el Impuesto sobre el Incremento del Valor de los Terrenos de Naturaleza Urbana, en el Impuesto Municipal sobre Gastos Suntuarios (art. 373.d) del RDLg 781/1986), en el art. 8 de la Ley 38/1992, reguladora de los Impuestos Especiales; la sustitución es una técnica jurídica que permite que un sujeto asuma una situación concreta que corresponde a otro, quedando éste liberado.... La sustitución no libera al sustituido de la obligación considerada en su globalidad...El sustituido debe reintegrar al sustituto la cantidad que proceda a través de técnicas diversas...El sustituto sí se coloca en lugar del contribuyente en la obligación tributaria, aunque no siempre en los deberes tributarios (obligaciones formales). En ningún caos, la sustitución por completa que sea supone la salida del círculo tributario del contribuyente. Éste queda obligado a reintegrar al sustituto la cantidad pagada en concepto de obligación tributaria...En definitiva, la sustitución completa lo es siempre en la totalidad de la obligación. En cuanto a los deberes habrá que estar a cada caso concreto. Los ejemplos más claros de sustitución se dan en el Derecho Tributario Municipal. El TRLRHL, art. 23, en relación con las tasas...Aún más nítida es la sustitución completa (en la obligación definitiva) en el Impuesto sobre Construcciones, Instalaciones y Obras (ICIO)...En el ordenamiento estatal, un ejemplo peculiar es el recargo de equivalencia dentro del IVA.... La sustitución es una técnica instrumental y el sustituto un colaborador de la Administración tributaria. CALVO ORTEGA, R.(2010), págs.175-178; En los gravámenes donde exista la figura del sustituto, éste puede ser el sujeto infractor, así en los IIEE de fabricación-sólo hidrocarburos y tabaco-(los representantes fiscales), en el ICIO (quienes soliciten las correspondientes licencias o realicen las construcciones, instalaciones u obras), en el también Impuesto sobre Gastos Suntuarios (los dueños de los cotos de caza y pesca). AA. VV. (Dir. HERRERA MOLINA, P. M.) [2004]: Factbook Fiscal, IEF, Thomson-Aranzadi, Navarra, pág. 272.

${ }^{26}$ La tesis del retenedor como sustituto en una obligación a cuenta es en la actualidad minoritaria (FERREIRO, ALONSO), siendo mayoría los autores que mantienen la identidad de la retención como obligación autónoma -con función cautelar en relación con el pago de una obligación futura e incierta- y del retenedor como deudor de una obligación propia (MARTÍN QUERALT, LEJEUNE, COLLADO, MORIES, ALGUACIL, LUCHENA). En opinión de BAYONA y SOLER ROCH, la obligación entre la Hacienda Pública y el retenedor, así como la obligación entre la Hacienda Pública y el obligado a ingresar a cuenta, constituye un vínculo autónomo, una obligación a cuenta - de naturaleza caucional o de garantía- (no entendida en sentido técnico de accesoriedad, ya que surgen de un presupuesto de hecho autónomo e, incluso, con independencia de que aquélla llegue a devengarse y también puede ser distinto el deudor que puede o no coincidir con el sujeto pasivo de la principal; la dependencia reside en los efectos jurídicos de la obligación a cuenta que van necesariamente referidos a la principal que, en su caso, debe surgir en el futuro... No obstante esta autonomía conceptual -entre retenedor u obligado a efectuar 


\section{obligados a practicar ingresos a cuenta ${ }^{27}$, c) los obligados al cumplimien-}

pagos a cuenta y los sustitutos- debe tenerse en cuenta que la obligación tributaria principal y las obligaciones tributarias a cuenta, sobre todo en el caso de la retención, son obligaciones conexas, de modo que determinadas consecuencias sobre el contribuyente y el retenedor que provoquen un enriquecimiento injusto de la Administración, son contrarias a Derecho, tal como ha establecido la doctrina legal del Tribunal Supremo (SsTS 27/2/2007, 8/3/2008). BAYONA DE PEROGORDO, J. J. y SOLER ROCH, M. T.(2010): Materiales de Derecho Financiero, Compás, Alicante, págs. 171, 199-200; Del art. 37.2 LGT... se desprende, con toda claridad, que la obligación del retenedor requiere la realización de dos presupuestos de hecho diferentes: Un primer presupuesto de hecho está constituido por uno de los componentes del elemento material del hecho imponible futuro e incierto en su realización, que puede determinar el nacimiento de una obligación tributaria principal igualmente futura e incierta. De este primer presupuesto de hecho se deriva, únicamente, la obligación de soportar la retención...Un segundo presupuesto de hecho engloba el anterior y configura el presupuesto de hecho de la obligación de retener e ingresar la cantidad retenida en el Tesoro. Estos dos presupuestos de hecho dan lugar a dos obligaciones distintas aunque íntimamente relacionadas: la obligación de soportar la retención y la obligación de retener e ingresar las cantidades retenidas. Y....se diferencian nítidamente de la obligación tributaria principal que, eventualmente, tendrá que pagar el contribuyente...A esta nítida diferencia se refiere, sin duda, el art. 23.1 LGT...La obligación del retenedor es autónoma, " distinta», claro está, de la obligación tributaria principal. Pero no es independiente de ella.... Naturalmente, si el sustituto ingresa las cantidades que hubiera debido retener sin haber efectuado la retención, tiene derecho, sobre la base del art. 37.2 y, sobre todo, del art. 38.3 LGT, a repetir el pago de quien debiera haber soportado la retención...basado esencialmente en la necesidad de subsanar el enriquecimiento injusto que puede producirse en el contribuyente si el retenedor ingresa a cuenta de su obligación de pago pero no le ha retenido. FERREIRO LAPATZA, J. J.(2006), págs. 439-442; Los sujetos obligados a retener o ingresar a cuenta están obligados a efectuar su ingreso en el Tesoro, sin que el incumplimiento de aquella obligación pueda excusarles de ésta. En este sentido debe recordarse que el incumplimiento de la obligación de retener o de ingresar a cuenta constituye una infracción tributaria de acuerdo con la LGT (art. 191) o delito de acuerdo con el CP (art. 305). El perceptor de rentas sobre las que deba retenerse a cuenta computará aquéllas por la contraprestación íntegra devengada y deducirá de su cuota la cantidad retenida. Sin embargo, si no se hubiera practicado retención o lo hubiera sido por un importe inferior al debido, por causa imputable al retenedor u obligado a ingresar a cuenta, el perceptor deducirá de la cuota la cantidad que debió ser retenida. En tal supuesto, la diferencia entre la cantidad efectivamente retenida y la cantidad deducida por el contribuyente le será exigida al sujeto que ha retenido incorrectamente. No obstante, en el caso de retribuciones legalmente establecidas que hubieran sido satisfechas por el sector público, el perceptor solo podrá deducir las cantidades efectivamente retenidas. FERREIRO LAPATZA, J. J.; MARTÍN FERNÁNDEZ, J.; RODRÍGUEZ MÁRQUEZ, J.; TOVILLAS MORÁN, J. M.(2008): Curso de Derecho Tributario. Parte especial. Sistema Tributario. Los tributos en particular, Marcial Pons, Madrid, págs. 146-147,209.

${ }^{27}$ CALVO ORTEGA lo considera como un tipo de sustitución.. CALVO ORTEGA, R. (2010), págs. 172 y 173. Así entiende que el contribuyente queda obligado a integrar en su obligación tributaria global las prestaciones realizadas por el retenedor. Este tipo de sustitución no supone un desplazamiento definitivo del contribuyente, de aquí que la expresión «sustitución»-que ahora expone- deba ser tomada con relatividad; También considera que lo más que se puede llegar a calificar al retenedor es como un caos de sustitución impropia, frente a la sustitución propiamente dicha. PÉREZ DE AYALA, J. L. y PÉREZ DE AYALA BECERRIL, M.(2004): Fundamentos de Derecho Tributario, Edersa, Dijusa, Madrid, pág. 126; para COLLADO YURRITA el retenedor a cuenta es un sustituto, pero no 


\section{to de obligaciones tributarias formales ${ }^{28}$, d) la sociedad dominante en el régimen de consolidación fiscal ${ }^{29}$, e) las entidades que estén obliga-}

ya un sustituto de la obligación tributaria en sentido estricto, sino de una obligación de anticipo del tributo. COLLADO YURRITA, M. A.(1992): «Configuración jurídica de la retención a cuenta en la Ley del IRPF de 6 de junio de 1991», Crónica Tributaria (CT), núm. 61, pág. 12; Para el retenedor y el obligado a ingresar a cuenta están desempeñando en el sistema una función análoga a la que, en su momento, cumplió el sustituto en los impuestos directos sobre la renta, y por ello esta modalidad de sujeto pasivo ha perdido incidencia dentro del sistema, lo que no significa que la sustitución sea un mecanismo jurídico superado. BAYONA DE PEROGORDO, J. J. y SOLER ROCH, M. T.(2010), págs. 248 y 261; Aceptan esta separación entre retenedores y sustitutos del contribuyente que defendieren Pérez Royo y Ferreiro. MARTÍNEZ LAGO, M. A.; APARICIO PÉREZ, J.; BAENA AGUILAR, A. y GARCÍA DE LA MORA, L.(1991): Delitos e infracciones Tributarias: Teoría y práctica, Lex Nova, Valladolid, pág. 29; Diferenciando el retenedor del sustituto, QUEROL GARCÍA admite que si el sustituto surge en lugar del contribuyente, el retenedor, puede aparecer, y de hecho aparece, con anterioridad a la realización del hecho imponible. Luego difícilmente puede aparecer sustituto del contribuyente que por no haber realizado el hecho imponible todavía no existe en el mundo tributario. QUEROL GARCÍA, M. T. (1991): Régimen de infracciones y sanciones tributarias, Deusto, Bilbao, pág. 48; El retenedor ni es sustituto del contribuyente ni es sujeto pasivo tributario. MUÑOZ BAÑOS, C.(1999): Infracciones tributarias y delitos contra la Hacienda Pública, Edersa, Madrid, págs.42 a 43.

${ }^{28}$ Un buen elenco de estos sujetos los encontramos en los arts. 93 a 95 de la LGT. MUÑOZ BAÑOS, C.(1999), pág. 48 y 49.

${ }^{29}$ Su régimen se contiene en los artículos 55 a 75 de la Ley 27/2014, de 27 de noviembre, del Impuesto sobre Sociedades (LIS). Los diferentes obligados tributarios que intervienen en el régimen de consolidación fiscal ostentan la condición de sujeto pasivo el grupo fiscal (art. 56.1 LIS); la de representante la sociedad dominante (art. 56.2 LIS); la de sujeto infractor la sociedad dominante (art. 181.1 LGT); la de responsables solidarios del pago de la deuda excluidas las sanciones, las sociedades que integran el grupo (art. 57 LIS); y la de obligado tributario para atender a la inspección sería la sociedad dominante como representante del grupo. Así si bien en el régimen de declaración consolidada el único sujeto infractor es la sociedad dominante, las infracciones que se cometan al margen del régimen de consolidación por las sociedades que integran el grupo fiscal tendrán como sujeto infractor a la sociedad que cometa dicha infracción; Opina MARTÍNEZ LAGO que este criterio no es absoluto, pues sólo afecta al Impuesto de Sociedades, y no a otros tributos (IVA, ITP, IAE). En estos casos, dado que la personalidad jurídica de las restantes Sociedades del grupo existen, pero mediatizadas, creemos que sólo será imputable la conducta de aquella Sociedad que haya actuado libremente. MARTÍNEZ LAGO, M. A.; APARICIO PÉREZ, J; BAENA AGUILAR, A. y GARCÍA DE LA MORA, L.: Delitos e infracciones Tributarias: Teoría y práctica, Lex Nova, Valladolid, 1991, pág. 29; En algunos casos no coinciden sujeto pasivo y sujeto infractor, así a la sociedad dominante como sujeto infractor, y en calidad de representante del grupo, se le incoará, en su caso, un acta cuyo contenido versará exclusivamente sobre la sanción impuesta. Por el contrario, el acta que se incoe para recoger la propuesta de liquidación tributaria...se extenderá al grupo, único sujeto pasivo, aún cuando la firma de la misma la realice la sociedad dominante, en su calidad de representante. QUEROL GARCÍA, M.T. (1991), pág. 52; El régimen de tributación consolidada y el de responsabilidad que permite imputar a la sociedad dominante la infracción, es únicamente aplicable al IS, porque en los demás tributos cada sociedad tributa de forma independiente y, por tanto, será cada una de ellas la que cometa, y a quien se imputen, las respectivas infracciones y sanciones. MUÑOZ BAÑOS, C.(1999), pág. 44; La dominante será sujeto infractor en el Impuesto sobre Sociedades, ya que en los demás conceptos tributarios, cada una de las sociedades 
das a imputar o atribuir rentas a sus socios o miembros, f) el representante legal de los sujetos obligados que carezcan de capacidad de obrar $^{30}$ en el orden tributario ${ }^{31}$.

integrantes del grupo podrá resultar, en su caso, sujeto infractor de manera independiente. AA. VV. (Dir. HERRERA MOLINA, P. M.)[2004], pág. 273; La comprobación e investigación de la sociedad dominante y del grupo fiscal se realizará en un único procedimiento de inspección, que incluirá la comprobación de las obligaciones tributarias del grupo fiscal y de la sociedad dominante objeto del procedimiento (art. 195.1 RGIT). De acuerdo con lo previsto en el artículo 68.1.a) de la Ley 58/2003, de 17 de diciembre, General Tributaria, el plazo de prescripción del Impuesto sobre Sociedades del grupo fiscal se interrumpirá: a) Por cualquier actuación de comprobación e investigación realizada con la sociedad dominante respecto al Impuesto sobre Sociedades. b) Por cualquier actuación de comprobación e investigación relativa al Impuesto sobre Sociedades realizada con cualquiera de las sociedades dependientes, siempre que la sociedad dominante tenga conocimiento formal de dichas actuaciones (art. 195.3 RGIT; art, 56.2 LIS; Instrucción 2/2006, 9 junio de la Dirección de Inspección Financiera y Tributaria)... En el Impuesto sobre Sociedades...no es necesario extender la diligencia A04 a la sociedad dominante ni acompañar informe ampliatorio a las diligencia A04 extendidas a las sociedades dependientes. Se incoará el expediente sancionador a la sociedad dominante por su condición de sujeto infractor al objeto de imponerle la sanción que proceda por la infracción cometida. En el IVA y resto de impuestos. Se incoan las actas que procedan a cada una de las sociedades sin que exista ninguna particularidad procedimental respecto del régimen general. Los sujetos infractores son cada una de las sociedades por las infracciones que hayan cometido, sean dominantes o dominadas. AA.VV. (Coord. PELÁEZ MARTOS, J. M. ${ }^{a}$ ) [2007:]Todo procedimiento Tributario 2007-2008. CISS, Valencia, págs. 836-839,1013.

${ }^{30}$ Capacidad contributiva es igual a capacidad económica- capacidad para contribuir-; Capacidad tributaria es igual a capacidad jurídica -capacidad válida para todo el ordenamiento referida al Derecho Tributario-...De acuerdo con la doctrina no sólo tradicional, sino todavía hoy absolutamente mayoritaria en nuestro país, entendemos que en nuestro ordenamiento jurídico capacidad es sinónimo de personalidad, pues -en palabras de Castán- implica aptitud para derechos y obligaciones o, lo que es igual, para ser sujeto, activo o pasivo, de relaciones jurídicas. Esta aptitud en que consiste la personalidad o capacidad jurídica se despliega en dos manifestaciones: aptitud del sujeto para la mera titularidad de las distintas situaciones de poder y deber reconocidas por el ordenamiento $\mathrm{y}$ aptitud para poder ejercitar y cumplir tales poderes y deberes. A la primera se le suele llamar capacidad de derecho o capacidad jurídica en sentido estricto. A la segunda se le llama comúnmente capacidad de obrar. Tales explicaciones del concepto capacidad pueden ser aplicadas sin modificaciones a la capacidad tributaria...Podemos hablar, por tanto, en Derecho Tributario de una capacidad jurídico-tributaria, aptitud para ser titular en el ámbito jurídico-tributario de poderes y deberes, y de una capacidad de obrar tributaria, aptitud para poder ejercitarlos y cumplirlos. Ambas,...no son más, insistimos, que las dos formulaciones de la capacidad, válidas en todo el ordenamiento, referidas a las situaciones, vínculos y relaciones propias de esta rama del Derecho. La capacidad, por tanto, señala el círculo de poderes y deberes que pueden ser asumidos por una persona, física o jurídica. FERREIRO LAPATZA, J. J.(2006), págs. 365-368.

${ }^{31}$ Destaca que sólo el representante de los obligados tributarios se haya incluido, habida cuenta que no hay coincidencia entre sujetos infractores y obligados tributarios, quedando imprevisto el representante de los no obligados, en cuyo caso quien comete la infracción siempre es el representante y no el representado. OCHOA destaca que «en cuanto al representante voluntario, la mención que el artículo 181.1.f LGT realiza al representante legal parece excluir al representante voluntario. Para apreciar la posible condición de sujeto infractor en el representante voluntario deberán tenerse en cuenta las 
El art. 181.1 LGT, tras realizar en su primer párrafo una declaración general de los sujetos infractores, establece un listado de sujetos que pueden tener, en particular, esa condición, listado que se considera superfluo $^{32}$ al poder haber quedado el precepto completo únicamente con el contenido de su primer párrafo, que ya recoge, en líneas generales, los titulares de los diferentes deberes tributarios cuya violación es considerada como infracción ${ }^{33}$.

Como ya se ha indicado, el apartado 1 del artículo 181 de la LGT contiene, junto a la definición de los sujetos infractores, una lista de

facultades conferidas al mismo en el poder que se le otorga. Si tiene poder suficiente para actuar ante la Administración tributaria, es lógico pensar que determinadas conductas realizadas personalmente por él no deben imputarse al obligado tributario al que representa.... Hay que tener en cuenta que alguna de las conductas ilícitas enumeradas en el artículo 29 LGT podrían imputársele directamente al representante voluntario ( que ostente poderes suficientes para actuar ante la Administración tributaria)». DÍEZ OCHOA, J. M.(2006), págs. 63 y 64; La autoría de la infracción por el representante legal fue defendida por PÉREZ ROYO, F.(1972): Infracciones y Sanciones Tributarias, IEF, Madrid, pág. 55; Las consecuencias que se deriven de la actuación del representante en el ejercicio de su actividad, le serán directamente imputables, de modo que será considerado autor de las infracciones tributarias que pudiese haber cometido por la gestión de los intereses de su representado. ÁLVAREZ MARTÍNEZ, J.(1995): La representación en el ordenamiento tributario. Marcial Pons, Madrid, pág. 273 y 299; STS de 2 de mayo de 1996; Acertadamente habla de representante legal de un incapaz sea o no sujeto pasivo, pero que ostente la obligado tributario dentro de las relaciones con la Hacienda Pública... Si tenemos en cuenta que el art. 181.1 LGT declara expresamente como sujetos infractores a la entidades del art. 35.4 LGT, está claro que su representante legal (art. 45.3 LGT) queda exonerado de responsabilidad, por lo que la expresión representante legal de los incapaces debe retrotraerse al Código Civil, y allí nos encontramos los que son representantes legales. MUÑOZ BAÑOS, C.(1999), págs. 53 y 54.

${ }^{2}$ El listado es incompleto y meramente descriptivo de un conjunto de vínculos unificados bajo la categoría (del incumplimiento) de la relación jurídico tributaria. En cuanto al carácter del listado podría decirse que casi todo gira alrededor del contribuyente aunque se le denomine de maneras muy diversas en función de la concreta obligación que aquél puede asumir dentro de la relación jurídico tributaria. MARTÍNEZ LAGO, M. A. y GARCÎA DE LA MORA, L. (2009): Lecciones de Derecho Financiero y Tributario, Iustel, Madrid, págs. 315 y 316; Se trata de un catálogo meramente ejemplificativo -y lleno de obviedades; Ibíd., pág. 516; carece de toda utilidad. REDONDO ANDREU, I.(2004): «La Potestad Sancionadora en materia tributaria y los sujetos infractores», en la obra colectiva (Dir. MARTÍNEZ LA FUENTE, A.): Estudios sobre la Nueva Ley General Tributaria, MEH, IEF, Madrid, pág. 796.

${ }^{33}$ PÉREZ ROYO, F. y AGUALLO AVILÉS, A.(1996): Comentarios a la Reforma de la Ley General Tributaria, Aranzadi, Navarra, págs. 223 y 226; para MORILLO MÉNDEZ, A. (1996): Las sanciones tributarias, Tirant lo Blanch, Valencia, hubiera bastado con la referencia a los autores y si se consideraba oportuno también a los cómplices, es decir, «hubiera bastado con una simple referencia a la participación (personal) en la comisión de las infracciones típicas», pág. 137; Sin embargo, el legislador no cierra la puerta a otros posibles sujetos infractores que la práctica del régimen sancionador nos vaya descubriendo. RAMÓN DE LA POZA, L. M.(2005): Procedimientos Tributarios. Infracciones y Sanciones, Ediciones Experiencia, Barcelona, pág. 30. 
quienes, entre otros, pueden ostentar dicha condición. Esta relación ejemplificativa tiene en realidad una relevancia escasa debido a su obviedad $^{34}$, pues se limita a mencionar algunos de los titulares de los deberes y obligaciones tributarias cuyo incumplimiento será constitutivo de algunas de las infracciones tipificadas en los artículos 191 a 206 de la LGT o en otras leyes especiales ${ }^{35}$.

\section{Así, resulta innecesaria, por evidente, la alusión a los contribuyen- tes $^{36}$ y sustitutos ${ }^{37}$ de los contribuyentes o a los retenedores y obligados}

${ }^{34}$ En opinión de PÉREZ ROYO, la utilidad de esta lista es ninguna. PÉREZ ROYO, F.(2004): Derecho Financiero y Tributario. Parte General, Civitas, Madrid, pág. 337. Sin embargo, cabe reseñar que la Comisión que elaboró el Informe para la reforma de la Ley General Tributaria consideró procedente el mantenimiento de la enumeración ejemplificativa de sujetos infractores, aunque sólo fuera por razones didácticas, Ibíd., pág. 182.

${ }^{35}$ De modo claramente asistemático y con poco carácter unificador de una Ley Tributaria que se denomina General.

${ }^{36}$ En el IRPF es la persona física que obtiene la renta -la unidad familiar no se configura como sujeto pasivo, sino como una agrupación de sujetos pasivos que tienen en común se pertenencia a la Unidad familiar-. En el Impuesto sobre sociedades, es la persona jurídica que obtiene la renta. En el Impuesto sobre el Patrimonio es la persona física que sea titular de los bienes o derechos sujetos a gravamen. En el Impuesto sobre sucesiones y donaciones son las siguientes personas físicas: En las adquisiciones mortis causa: los causa-habientes; en las donaciones y demás transmisiones lucrativas inter vivos equiparables, el donatario o el favorecido por ellas; en los seguros sobre la vida, los beneficiarios; En el IVA la persona física, jurídica o entidad del art. 35.4 LGT, que realice las entregas de bienes y prestaciones de servicios, las adquisiciones de bienes o las importaciones sujetas al impuesto. AA.VV. (Coord. PELÁEZ MARTOS, J. M.ª) [2007], págs. 210-211.

${ }^{37}$ Contemplado en el art. 36.3 LGT, de este artículo se desprende claramente, y en primer lugar, que el nacimiento de la obligación del sustituto requiere la realización de dos presupuestos de hecho diferentes: el hecho imponible del que nace la obligación tributaria a cargo del contribuyente, y otro presupuesto de hecho -distinto del hecho imponible- que engloba al hecho imponible y del que nace la obligación del sustituto de pagar a la Administración financiera las cuotas del tributo, v.gr. art. 23.2. ${ }^{\circ}$ RDLg. 2/2004). En segundo lugar, señala la necesidad de que el sustituto, como todo sujeto pasivo, y de acuerdo con las exigencias del principio de legalidad, haya de estar determinado por una norma con rango de Ley. En tercer lugar, el sustituto está obligado a cumplir la obligación tributaria principal, así como las obligaciones formales inherentes a ella...Del hecho imponible, pues, nace sólo la obligación tributaria principal, y la obligación tributaria principal nace sólo de la realización del hecho imponible. Del otro presupuesto de hecho que genera la sustitución nace, pues, otra obligación que, siendo distinta de la obligación tributaria principal por su distinto presupuesto de hecho y por su distinto sujeto pasivo, tiene como objeto, sin embargo, una prestación igual, entregar la cuota debida como tributo...Dos obligaciones distintas que- contra lo que con frecuencia se lee- no pueden calificarse como dos obligaciones autónomas y, en este sentido, «independientes». La sustitución...completa -que designa aquellos casos en que la Ley ordena pagar al sustituto y ordena a la Hacienda Pública que exija el pago al sustituto y sólo al sustituto, sin que pueda dirigirse en ningún caso al contribuyente sustituido... Una sustitución de este tipo entiendo que es contraria a las funciones que el sustituto debe cumplir en un sistema racional ordenado conforme al principio de capacidad...Y posibilita, en caso del sustituto insolvente que ni retiene ni paga, el impago también por un contribuyente que se vería injustamente enriquecido en contradicción evidente con el principio de capacidad... es

(C) UNED. Revista de Derecho UNED, núm. 17, 2015 


\section{a practicar ingresos a cuenta ${ }^{38}$, quienes por su condición de deudores}

este el supuesto de sustitución completa el que parece contemplar el art. 36.3 LGT, con un completo silencio sobre la posibilidad de que la Hacienda Pública se dirija al contribuyente sustituido para exigirle el cumplimiento de la obligación no cumplida por el sustituto. Aunque, como es lógico, la ley de cada tributo sí puede contemplar esta posibilidad. FERREIRO LAPATZA, J. J.(2006), págs. 435-438; Esta figura tuvo gran importancia en el sistema fiscal anterior a la reforma del año 1978...En la actualidad tiene carácter residual. Como ejemplo de la misma cabe señalar el ICIO y las Tasas Municipales por Licencias urbanísticas. AA.VV. (Coord. PELÁEZ MARTOS, J. M. ${ }^{a}$ ) (2007), pág. 212.

${ }^{38} \mathrm{La}$ atribución de obligación autónoma le confiere una especial cualidad de pervivencia per se aún cuando el obligado haya regularizado de hecho deduciendo lo efectivamente retenido, ingresado a cuenta o pagado fraccionadamente, a la hora de presentar la autoliquidación definitiva. En el caso de retenciones, estos efectos ha servido y siguen sirviendo de fundamento para una crítica permanente a la pervivencia de la naturaleza autónoma de la obligación, cuando se ha producido la regularización ...dado que en estos casos, y a pesar de la regularización, la Administración tributaria seguirá exigiendo el ingreso de las retenciones al retenedor, aunque paralelamente pueda efectuar una devolución del exceso ingresado por el retenido, devolución que se ejecutará siempre que sea posible y no hay jugado el instituto de la prescripción, en cuya situación,... se produciría un doble ingreso en el Tesoro..... un enriquecimiento de la Administración tributaria. .... Respecto al tipo específico de incumplimiento de la obligación de retener, éste no existe en el articulado de la LGT, aunque se hace uso de tal conducta......(en el) artículo 191.4 LGT..... Entonces, si no hay tipo específico ¿a qué obedece su inclusión específica en la lista aclaratoria?¿¿por qué no se ha seguido la misma pauta que con los obligados a realizar pagos fraccionados? Quizá lo que fundamente la diferencia de tratamiento sea el hecho de que quien no realiza pagos fraccionados incide sobre su propia cuenta corriente tributaria, sobre sus propios impuestos, que más tarde regularizará indefectiblemente... Evidentemente, el retenedor que no retiene o retiene mal o el obligado a ingresar a cuenta que incumple o cumple incorrectamente su obligación, no regularizan ellos mismos sus incorrecciones y solamente en el caso de que el retenido declare, tal regularización tendrá lugar. No sucederá así cuando el retenido no tenga obligación de declarar, como ocurre con los comunicantes o solicitantes de devolución rápida en IRPF, donde la retención defectuosa se puede convertir en impuesto definitivo de hecho del retenido. LAMOCA PÉREZ, C.( 2005): Infracciones y sanciones tributarias. Análisis crítico del nuevo sistema de infracciones y sanciones en la Ley General Tributaria, CEF, Madrid, pág. 156; Con carácter general están obligados a retener o ingresar a cuenta en la medida que abonen o satisfagan rentas sujetas al IRPF (art. 99.2 LRIPF; arts. 74 RIPRF) o IS (art. 128.1 LIS; art. 60 RIS): las personas jurídicas y las entidades del art. 35.4 LGT; y los contribuyentes por IRPF que ejerzan actividades económicas (profesionales, empresarios, agricultores, etc) cuando satisfagan rentas en el ejercicio de sus actividades; Las personas físicas, jurídicas y demás entidades no residentes en territorio español, que operen en él mediante establecimiento permanente, o sin establecimiento permanente respecto a los rendimientos de trabajo que satisfagan, así como respecto de otros rendimientos sometidos a retención o ingreso a cuenta que constituyan gasto deducible para la obtención de determinadas rentas.... Las obligaciones del retenedor $u$ obligado a ingresar a cuenta son ingresar en el Tesoro el importe de la deuda tributaria correspondiente a la retención practicada o que debió haberse practicado o al ingreso a cuenta, sin que el incumplimiento de la obligación de retener pueda excusarle de la obligación de ingresar; presentar una declaración resumen anual (modelos. 180,187,188,190,193,194,196 296); expedir una certificación acreditativa de las retenciones practicadas o los ingresos a cuenta efectuados; y comunicar a los contribuyentes la retención o ingreso a cuenta practicado. AA. VV. (Coord. PELÁEZ

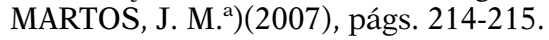


principales del tributo ${ }^{39}$, pueden, sin duda, protagonizar las infracciones derivadas del incumplimiento de las prestaciones legalmente impuestas a los mismos. Igualmente, obvia es la posibilidad de que los obligados al cumplimiento de las obligaciones tributarias formales sean sujetos infractores, en caso de que dichas obligaciones no se cumplan correctamente. Tampoco plantea dudas -salvo los problemas de carácter general para todo tipo de personas jurídicas o entidadesla alusión a la sociedad dominante ${ }^{40}$ en el régimen de consolidación fiscal $^{41}$, pues es ella la que, por imperativo legal, ha de hacerse cargo del cumplimiento de las obligaciones fiscales del grupo y la que en consecuencia será artífice de los incumplimientos producidos al respecto $^{42}$.

${ }^{39}$ Todo ello basado en el 'principio de no indiferencia' en relación con el sujeto que al final de un procedimiento (en ocasiones complejo) ha cumplido la obligación. CALVO ORTEGA, R.(2010).

${ }^{40}$ Así pues, el incumplimiento de las obligaciones materiales o formales derivadas de la aplicación del régimen especial de los grupos de sociedades nunca dará lugar a una responsabilidad directa de las sociedades dominadas sobre el importe de la sanción. Como señala Pérez Royo, «es lógico que la ley considere que las infracciones que, eventualmente se produzcan en relación a la aplicación del mencionado régimen de tributación consolidada sean imputables a la sociedad dominante, a través de la cual se expresa la voluntad del grupo»- Efectivamente, si la sociedad dominante actúa como representante del grupo, o sea, de las demás sociedades que integran un ente sin personalidad jurídica propia, de los mencionados en el artículo 35.4 de la LGT, es lógico que sea el representante, y no los representados, quien sea sancionado por el incumplimiento de las obligaciones tributarias que el primero debió cumplir en representación de los segundos. Las sociedades dominadas, por su parte, podrán ser consideradas como sujetos infractores exclusivamente por el incumplimiento de las obligaciones de las que derivan del régimen individual de cada una de ellas, nunca de las obligaciones de las que derivan de la aplicación del régimen especial de los grupos de sociedades. Por tanto, tras la entrada en vigor de la extinta Ley 43/1995, y por exigencias del principio de personalidad de la sanción, ni las sociedades dominadas responderán de las sanciones impuestas a la sociedad dominante que, actuando en representación de las demás sociedades integrantes del grupo, ha incumplido las obligaciones tributarias materiales y formales que se deriven del régimen de los grupos de sociedades, ni tampoco sociedad alguna perteneciente al grupo, ya sea dominante o dominada, responderán de las sanciones impuestas a cualquiera de las sociedades integrantes del mismo grupo por incumplir las obligaciones tributarias que se derivan del régimen individual de tributación

${ }^{41}$ Régimen que se recoge en los arts. 55 y ss. De la Ley 27/2014, de 27 de noviembre, del Impuesto sobre Sociedades (LIS). En concreto, su artículo 57 regula las «Responsabilidades tributarias derivadas de la aplicación del régimen de consolidación fiscal»: Las entidades del grupo fiscal responderán solidariamente del pago de la deuda tributaria, excluidas las sanciones.

${ }^{42}$ El apartado 2 del artículo 56 LIS dispone que «tendrá la consideración de entidad representante del grupo fiscal la entidad dominante cuando sea residente en territorio español, o aquella entidad del grupo fiscal que este designe cuando no exista ninguna entidad residente en territorio español que cumpla los requisitos para tener la condición de dominante ». El hecho de que el sujeto pasivo lo sea el grupo, ha movido a la LGT a aclarar que es la sociedad dominante la que debe ser calificada como sujeto infractor. El grupo no tiene personalidad jurídica propia y debe de actuar a través de su representante,

(C) UNED. Revista de Derecho UNED, núm. 17, 2015 
Lo mismo cabe decir con relación a las entidades que están obligadas a imputar rentas a sus socios o miembros, que tendrán lógicamente la condición de autor de las infracciones previstas en los artículos 196 y 197 de la LGT ${ }^{43}$; o de las entidades en régimen de atribución de rentas (ERAR) ${ }^{44}$, en caso de que incumplan alguna de las obligaciones que su regulación les impone. En cuanto a técnica de tipificación de la LGT hemos de expresar que, para las Entidades en régimen de atribución de rentas (ERAR), no se contiene una tipificación específica ${ }^{45}$

en este caso la sociedad dominante, la cual está sujeta al cumplimiento de todas las obligaciones, tanto formales como materiales que se deriven de la aplicación de este régimen especial. El incumplimiento de esas obligaciones podrá llevarla a su consideración como sujeto infractor. Es de tener en cuenta que las dominadas no son responsables de la sanción, sin perjuicio de que todas las sociedades miembros del grupo puedan ser por sus propias obligaciones, sujetos infractores.

${ }^{43}$ Pueden ser responsables de la infracción tributaria no sólo las personas físicas, sino también las jurídicas, incluso los entes en régimen de imputación de rentas, sin personalidad. Como ha declarado el TC en S 246/1991, de 19 de diciembre, nuestro Derecho administrativo admite la responsabilidad directa de las personas jurídicas, reconociéndoles, pues, capacidad infractora. Pero esto no significa en absoluto que para el caso de las infracciones administrativas cometidas por personas jurídicas se haya suprimido el elemento subjetivo de la culpa sino simplemente que ese principio se ha de aplicar de forma distinta a como se hace respecto de las personas físicas. Esta construcción distinta de la imputabilidad de la autoría de la infracción a la persona jurídica nace de la propia naturaleza de ficción jurídica a la que responden estos sujetos. CHOCLÁN MONTALVO, J. A.(2005): Responsabilidad Tributaria por los conceptos. Una aplicación razonable del principio de culpabilidad. Diario La Ley, núm. 6200. Martes, 1 de marzo de 2005.

${ }^{44}$ Así en el régimen sancionador se tipifica en el art. 191 LGT como infracción tributaria la falta de ingreso total o parcial de la deuda tributaria de los socios, herederos, comuneros o partícipes derivada de las cantidades no atribuidas o atribuidas incorrectamente por las entidades en atribución de rentas. Así, en el caso de una comunidad de bienes, dicha entidad puede ser sujeto infractor por conductas relacionadas con obligaciones formales, o por la falta de ingreso de impuestos en los que sea sujeto pasivo, como el IVA. Pero no será sujeto infractor por la renta no declarada de la entidad, ya que corresponde hacerlo a sus socios y, por tanto, ellos son los sujetos infractores mencionados en el art. 191 LGT. AA. VV. (Coord. PELÁEZ MARTOS, J. M.a) (2007), págs. 682-683.

${ }^{45}$ Así el actual art. 70.1 RD 439/2007 no recoge, respecto de las obligaciones de información, que uno de sus destinatarios sea la Administración tributaria.... Por su parte este apartado 43.4 LGT 1963 [actual 45.3 LGT] dispone que «Por los entes a los que se refiere el apartado 4 del artículo 35 de esta ley actuará en su representación el que la ostente, siempre que resulte acreditada en forma fehaciente y, de no haberse designado representante, se considerará como tal el que aparentemente ejerza la gestión o dirección y, en su defecto, cualquiera de sus miembros o partícipes»...entidades..entre las que se incluirían las sociedades civiles con personalidad jurídica que, de acuerdo con lo prescrito en el art. 72 LIRPF 40/1998 [actual art. 87 LRIPF 35/2006] están también sujetas al régimen de atribución de rentas, de este modo se puede concluir, recapitulando, que la obligación de información que deben cumplir estas entidades deberá ser cumplida por quien ostente la representación, y de no haberse nombrado representante o no constar tal nombramiento de forma fehaciente, dicha obligación recaerá en quien aparentemente ejerza la gestión o dirección, y por último, ya que se trata de criterios sucesivo, recaerá tal deber en cualquiera de los socios, herederos, comuneros o partícipes de las entidades sujetas al régimen de atribución de rentas. AA. VV. (Coord. CRUZ AMORÓS, M.) [2003]: Comentarios a 
sobre una hipotética conducta infractora de las entidades, pero sí una mención concreta a la que puedan observar sus miembros si dejan de ingresar ${ }^{46}$, de modo que cuando éstas no comunican o comunican cifras falsas o incorrectas a sus miembros la conducta no está tipificada. En estas entidades, parece que se ha optado por calificar como infracción, exclusivamente, la falta de ingreso de la deuda de los miembros de la ERAR $^{47}$, derivada de las cantidades no atribuidas o atribuidas incorrectamente por la entidad, ex artículo 191.1.2. ${ }^{\circ}$ LGT $^{48}$, aunque, por el artículo 195, también cabría sancionar a la $\operatorname{ERAR}^{49}$ por acreditar partidas aparentes a compensar o deducir en declaraciones de terceros ${ }^{50}$.

Igualmente, la LGT tipifica en sus artículos 196 y 197, pero únicamente para las Entidades en régimen de imputación de rentas $(\mathrm{ERIR})^{51}$, la falta de comunicación o la comunicación de ci-

la Ley del Impuesto sobre la Renta de las Personas Físicas y a la Ley del Impuesto sobre la Renta de No Residentes, Lex Nova, Valladolid, pág. 441-444.

${ }^{46}$ DÍEZ OCHOA, J. M.(2006), pág. 60.

${ }^{47}$ Ejemplificativamente, destacamos las herencias yacentes, comunidades de bienes, cuentas en participación, etc. Su régimen se encuentra en los artículos 86 a 90 de la Ley 35/2006 (IRPF)

${ }^{48}$ LAMOCA PÉREZ, C.(2005), pág. 49; Siendo esto así, la conclusión que obtenemos es que, en la mayor parte de las ocasiones, el partícipe de la entidad que no elabora su declaración, por carecer de la información, o la confecciona con los datos erróneos suministrados por la entidad del art. 33 de la LGT no padecerá consecuencia sancionadora alguna, por falta de culpabilidad. Sobre todo, le resultará muy difícil a la Administración demostrar la existencia de dicha culpabilidad, habida cuenta de que la única prueba tangible disponible, como es la notificación de la entidad, indica el camino contrario. De esta regla general sólo podrán exceptuarse, si acaso, supuestos marginales, como el de pequeñas entidades donde pueda considerarse como negligente el comportamiento del partícipe que no detecta el error en la comunicación, por evidente, o el del partícipe que es, a la vez, el representante o gestor de la entidad. RODRÍGUEZ MÁRQUEZ, J. (2003): «La colaboración de terceras personas en las infracciones tributarias: el caso particular de las entidades en régimen de atribución de rentas», $J T$, núm. 4, pág. 2.

${ }^{49}$ Las ERAR extranjeras [art. 34 TRLIRPFNR]cuyos miembros sean en su totalidad residentes en nuestro país a efectos fiscales, se encontrarán fuera del ámbito de la TRLIRPFNR. Por el contrario, las ERAR españolas con miembros no residentes, quedan reguladas por la TRLIRPFNR. AA.VV. (Coord. CRUZ AMORÓS, M.) [2003], págs. 748-750.

${ }^{50}$ Con anterioridad existía una laguna de punibilidad, al no poder demostrarse su culpabilidad -de la ERAR- en la mayor parte de las ocasiones. En los casos residuales en que esto sea posible, no nos cabe la menor duda de que la entidad en régimen de atribución de rentas podrá ser declarada responsable solidaria. Rodríguez Márquez, J.(2003), pág. 2; Para las ERAR o ERIR existe una infracción tributaria consistente en el falseamiento de los resultados a imputar a los socios de este tipo de sociedades. Por ello, las sociedades tienen la consideración de sujetos en este tipo de infracciones. DELGADO GARCÍA, A. M. ${ }^{a}$; OLIVER CUELLO, R.(2008): Los procedimientos en el ámbito tributario, UOC, Barcelona, pág. 288.

${ }^{51}$ Son ejemplos de este tipo social, las UTE, las antiguas sociedades transparentes, y sociedades en transparencia fiscal internacional. Su régimen se encuentra en los artícu- 
fras falsas o incorrectas a sus miembros. En este caso, se ha optado por tipificar la conducta de la entidad y sancionar, en la misma, los incumplimientos producidos, sin ninguna alusión concreta a las conductas infractoras que puedan tener los miembros por dejar de ingresar la cuota resultante de la comunicación incorrecta o la falta de comunicación, aunque se podría utilizar el artículo 191 LGT para sancionar a los miembros de las ERIR por dejar de ingresar.

Por lo que respecta, finalmente, al representante legal de los sujetos obligados que carezcan de capacidad de obrar en el orden tributario, será aquel quien se hace cargo del cumplimiento de los deberes y obligaciones fiscales de su representado, será, lógicamente, a quien se deban imputar las infracciones de los citados deberes, en atención al principio de personalidad de la sanción ${ }^{52}$. Por su parte, los representantes voluntarios también pueden realizar las acciones y omisiones tipificadas como infracciones tributarias, especialmente, en aquellos casos en los que la Ley obligue a designar un representante obligado a cumplir las obligaciones tributarias del representado -como en el IRPF de los no residentes-. En cambio, no serán sujetos infractores y, consiguientemente, responsables de la deuda tributaria, los representantes de entidades sin personalidad jurídica, pues, en este caso, será el ente sin personalidad jurídica, y no el representante, a quien la Ley considere como sujeto infractor, tal y como se desprende del tenor literal del artículo 181.1 de la LGT.

Similar sería el caso de la representación legal, o según ESEVE$\mathrm{RRI}^{53}$, orgánica o corporativa establecida en el art. 45.2 LGT y que corresponde a los representantes de las personas jurídicas que ejercen la representación de las personas y de sus órganos y que se recoge en las leyes mercantiles y en las específicas reguladoras de este tipo de

los 43 a 47 (LIS); Para ZORNOZA estas entidades no son capaces de acción en sentido natural, ni respecto de ellas es posible apreciar la concurrencia del elemento subjetivo por el principio de la personalidad e incomunicabilidad de la sanción y por el principio de culpabilidad,, en los términos propios de la teoría penal, que deberá apreciarse respecto de las personas físicas a través de la cuales se produce su actuación. ZORNOZA PÉREZ, J. J. (1992): El sistema de infracciones y sanciones tributarias. Los principios constitucionales del derecho sancionador, Civitas, Madrid, págs. 182 y 183.

${ }^{52}$ Así, el Tribunal Supremo, en Sentencia de 24 de enero de 1996, concluye que en un caso de omisión de la declaración del Impuesto sobre la Renta de las Personas Físicas por parte de uno de los cónyuges, que padece incapacidad a causa de una hemiplejía y posterior situación meramente vegetativa, el otro cónyuge, en cuanto representante legal, tiene la obligación de presentar las oportunas declaraciones, por lo que existe responsabilidad inmediata de éste por la infracción cometida.

${ }^{53}$ ESEVERRI MARTÍNEZ, E.(2011): Derecho Tributario. Parte General, Tirant lo Blanch, Valencia, págs.144-145. 
entidades. De éste supuesto debemos separar el prevenido en el art. 47 LGT de representación legal -no orgánica- de personas jurídicas no residentes en España, en que la designación del representante será exigible cuando operen en España mediante establecimiento permanente, cuando así lo exija la normativa tributaria de modo específico o cuando así lo requiera la Administración atendiendo a la naturaleza de la operación efectuada en España o de la cuantía de la renta obtenida en territorio patrio.

Los sujetos infractores, a que se acaba de hacer referencia, tendrán, de conformidad con lo que establece el apartado 2 del artículo 181 de la $\mathrm{LGT}^{54}$-al regular la solidaridad de sujetos infractores, reiterada en el art. 182 LGT $^{55}$-, la consideración de deudores principales, a efectos de lo dispuesto en el apartado 1 del artículo 41 de la LGT en relación con la declaración ${ }^{56}$ de responsabilidad en el pago de la sanción tributaria. Esto es, dicha consideración se tiene, única y exclusivamente, a los efectos de que, junto ${ }^{57}$ a tal o tales sujetos, puedan colocarse otros suje-

${ }^{54}$ El sujeto infractor tendrá la consideración de deudor principal a efectos de lo dispuesto en el apartado 1 del artículo 41 de esta ley en relación con la declaración de responsabilidad.

${ }^{55}$ Artículo 182 LGT. Responsables y sucesores de las sanciones tributarias. 1. Responderán solidariamente del pago de las sanciones tributarias, derivadas o no de una deuda tributaria, las personas o entidades que se encuentren en los supuestos de los párrafos a) y c) del apartado 1 del artículo 42 de esta ley, en los términos establecidos en dicho artículo. El procedimiento para declarar y exigir la responsabilidad solidaria será el previsto en el artículo 175 de esta ley. 2. Responderán subsidiariamente del pago de las sanciones tributarias las personas o entidades que se encuentren en el supuesto del párrafo a) del apartado 1 del artículo 43 de esta ley, en los términos establecidos en dicho artículo. El procedimiento para declarar y exigir la responsabilidad subsidiaria será el previsto en el artículo 176 de esta ley. 3. Las sanciones tributarias no se transmitirán a los herederos y legatarios de las personas físicas infractoras. Las sanciones tributarias por infracciones cometidas por las sociedades y entidades disueltas se transmitirán a los sucesores de las mismas en los términos previstos en el artículo 40 de esta ley.

${ }^{56}$ En cualquier caso, la declaración de responsabilidad, tal y como apunta FALCÓN, «no es una mera actuación tendente al cobro de una cantidad ya liquidada, sino una verdadera y propia liquidación, o al menos una manifestación de la autotutela declarativa»26. El acto de liquidación no consiste sólo en determinar la existencia y cuantía de la deuda, sino también en fijar el obligado tributario a satisfacerla. Es decir, al derivar la acción frente al responsable, se está ejerciendo el derecho a determinar la deuda tributaria. 26 El citado autor llega a esta conclusión porque, después de analizar el inicio de la prescripción del responsable solidario, considera que la derivación de la responsabilidad no se integra en el procedimiento recaudatorio, sino que al formar parte de la autotutela declarativa, debe equipararse a una liquidación. FALCÓN Y TELLA, R. (2001): «La prescripción de la obligación tributaria en relación con el responsable: un problema mal planteado», QF, n. ${ }^{\circ} 12$, pág. 6.

${ }^{57}$ Junto al infractor principal situamos a otros, aunque su existencia depende del acto administrativo de la derivación, sin dicho acto no existe responsabilidad alguna 
tos a título de responsables ${ }^{58}$ de las consecuencias económicas con carácter solidario (art. 42.1.a y $c^{59}$, y $42.2^{60}$ LGT) o subsidiario ${ }^{61}$ (art.

(STC 140/2010), lo que la dota de naturaleza garantista, accesoria y subordinada a otra principal.

${ }^{58}$ SIMÓN ACOSTA entiende que nos hallamos ante un supuesto de excepción al principio de personalidad de las sanciones. SIMÓN ACOSTA, E.(2004): La nueva Ley General Tributaria, Civitas, Madrid, págs. 713 y 722; Para otros autores, no se trata aquí realmente de que la responsabilidad de una persona se traspase a otra, sino que ante diversos infractores que hayan cometido un mismo hecho, la responsabilidad por la sanción, que, en principio, correspondería a todos ellos, podrá exigirse por la Administración, individualmente y por el integrum a cualquiera de ellos, como dispone también el art. 130.3 LRJPAC.; Matizadamente ALMENAR BERENGUER Y RIPLEY SORIA indican que en el caso de que la Administración no pueda cobrar la sanción de aquel a quien se ha dirigido inicialmente, podrá acudir a los demás sujetos infractores, pero deberá tramitar respecto de ellos el correspondiente procedimiento sancionador, ya que no tendrá título de crédito alguno frente al sancionado si no ha dictado sanción contra él en el que pueda alegar lo que tenga por conveniente. HERRERO DE EGAÑA Y ESPINOSA DE LOS MONTEROS, J. M. (coord.) (2008): Comentarios a la Ley General Tributaria, Volumen II, Thomson-Aranzadi, Cizur Menor, Navarra, pág. 1324.

${ }^{59}$ Mientras que el término explotación económica es sinónimo de empresa o el de explotación es sinónimo de principal establecimiento (art. 9.1 Real Decreto Legislativo 1/2010, de 2 de julio, por el que se aprueba el texto refundido de la Ley de Sociedades de Capital), en el significado que actualmente le otorga la doctrina mercantil, esto es, empresa en sentido objetivo, y en su sentido objetivo la empresa no se ejerce, sino que en relación con la misma se puede ser titular, por el contrario, el término de actividad económica es equivalente a empresa, en sentido subjetivo, sin que nadie pueda ser titular de la empresa en este sentido, pudiendo tan sólo ser ejercida.

${ }^{60}$ Las conductas a que refiere el art. 42.2 LGT incorporan un amplio elemento de voluntariedad y consciencia en la participación en el levantamiento del embargo, aunque resulta difícil encontrar una sanción tributaria en la que, «en su caso»-como indica el precepto, se haya podido participar por parte este tipo de responsable tributario solidario, por lo que no respondería de las sanciones del infractor principal, pues ningún nexo -en la comisión de un acto ilícito- existiría entre ambos sujetos (por lo que resultar necesario indagar en este postulado normativo que tratamos y en la razonabilidad interna y externa del precepto, así como en su equidad y proporcionalidad -tanto en el sentido económico como en la exigencia colaborativa [prohibición de exceso] que requiere el artículo-). Por su parte, -y esa debe de ser la finalidad- el responsable tributario sí responderá «en todo caso» de la deuda que ha permitido que se minore en el proceso de recaudación, resultando un garante que evite el levantamiento de bienes embargables. En relación al supuesto del art. 42.2.b) no concurrirá el presupuesto previsto para aplicar tal hipótesis de responsabilidad solidaria cuando el incumplimiento de la diligencia de embargo derive de una previa conducta de la Administración tributaria, no reputándose siempre irrelevante, por tanto, la causa que haya dado lugar a la obstaculización del procedimiento de recaudación forzosa (STS de 20 de abril de 2012). De Miguel Arias, S (2013): «El nuevo supuesto de responsabilidad tributaria de administradores de personas jurídicas del artículo 43.2 de la LGT», Revista Quincena Fiscal núm.. 12/2013 parte Estudio, BIB 2013\1287.

${ }^{61}$ La responsabilidad subsidiaria parece ser la formula más respetuosa con el principio de proporcionalidad o de mínima intervención. los responsables subsidiarios, frente a lo que sucede con los solidarios, cuentan con el llamado «beneficio de excusión», traducido en la necesidad de que se declaren fallidos tanto a los deudores principales como a sus responsables solidarios, si los hubiera, antes de que la Administración pueda dictar un acto declarativo de responsabilidad frente al responsable subsidiario. 


\section{$43^{62} .1 . a, g$ y $h^{63}$ LGT), a los que la ley permite extender la responsabili- dad por las sanciones impuestas a aquél o aquéllos, en cuanto autor o autores directos y principales del ilícito ${ }^{64}$ tributario. Esta derivación ${ }^{65} \mathrm{o}$}

${ }^{62}$ El artículo 40.2 de la Ley 230/1963, modificado por la Ley 60/1969, disponía: «2. Serán responsables subsidiarios los Síndicos, Interventores o Liquidadores de quiebras concursos, Sociedades y Entidades en general, cuando por negligencia o mala fe no realicen las gestiones necesarias para el íntegro cumplimiento de las obligaciones tributarias devengadas con anterioridad a dichas situaciones y que sean imputables a los respectivos sujetos pasivos». Y el artículo 43.1.c) de la Ley 58/2003 ha venido a disponer: «1. Serán responsables subsidiarios de la deuda tributaria las siguientes personas o entidades: (...) c) Los integrantes de la administración concursal y los liquidadores de sociedades y entidades en general que no hubiesen realizado las gestiones necesarias para el íntegro cumplimiento de las obligaciones tributarias devengadas con anterioridad a dichas situaciones e imputables a los respectivos obligados tributarios. De las obligaciones tributarias y sanciones posteriores a dichas situaciones responderán como administradores cuando tengan atribuidas funciones de administración». El artículo 43.1.c) de la Ley 58/2003 omite la referencia a la negligencia o mala fe que hacía el artículo 40.2 de la Ley 230/1963, circunscribiéndose a declarar la responsabilidad subsidiaria de los liquidadores de sociedades que no hubiesen realizado las gestiones necesarias para el íntegro cumplimiento de las obligaciones tributarias devengadas con anterioridad a dichas situaciones e imputables a los respectivos obligados tributarios. Los cambios legislativos que se han producido en esta materia de la responsabilidad subsidiaria no impiden llegar a la conclusión de que, a pesar del cambio de redacción de la Ley, la responsabilidad no es objetiva, sino que se exige falta de diligencias en el cumplimiento de las obligaciones del responsable para con el fisco. La recurrente parece entender que sus únicas obligaciones son aquellas que aparecen especificadas en las Leyes societarias. Y ello no es así. El deber de diligencia que tienen las administraciones y los liquidadores es un deber de diligencia genérico para el conjunto de actividades que debe desarrollar en beneficio de la sociedad, y por tanto también en beneficio de aquellas personas que tienen derecho a obtener algo de la sociedad. Las Leyes societarias no pueden detallar la serie de actos concretos en que se traducen las obligaciones de diligencia de los administradores y todos ellos deben entenderse incluidos entro del deber de diligencia que tienen los administradores y liquidadores; las Leyes Fiscales lo que señalan es que esa falta de diligencia respecto del cumplimiento de los deberes fiscales, produce esa responsabilidad subsidiaria (STS 12.12.2013, FJ 5).

${ }^{63}$ En este supuesto también se pretende, aunque de modo subsidiario, garantizar el cobro, de modo que se extiende, indiscriminada y extensivamente, a quienes directa o indirectamente, y tengan el control total o parcial, les obliga a asumir «la total» cuantía derivada de deudas tributarias y de sanciones -entendemos tributarias y no de otro orden-. Respecto del objeto de este artículo, defendemos que debe existir una cierta participación -de menor calado que en la responsabilidad solidaria- en la comisión de la infracción tributaria.

${ }^{64}$ OCHOA indica que "..dicho precepto configura al sujeto infractor como deudor principal de la sanción contra el que habrá que llevarse a cabo la gestión recaudatoria de la misma, sin perjuicio de que, una vez iniciado el período ejecutivo de cobro de la sanción, se pueda posteriormente proceder, mediante el correspondiente expediente de derivación de responsabilidad, contra otros responsables de la sanción. DÍEZ OCHOA, J. M. (2006), pág. 67.

${ }^{65}$ El presupuesto de hecho de la responsabilidad subsidiaria debe efectuarla la Administración, y resulta recurrible ante la jurisdicción contenciosa, y no debe declararla la jurisdicción mercantil (art. 9.4 LOPJ). Además, ex art. 212.3 LGT: «La interposición en tiempo y forma de un recurso o reclamación administrativa contra una sanción producirá los siguientes efectos: a) La ejecución de las sanciones quedará automáticamente 
traslación de la responsabilidad en el pago se efectúa no ya fundada en principios de justicia, sino en motivos de prudencia política o social protegiendo a la Administración acreedora de la sanción de la insolvencia del infractor sancionado.

Debemos hacer constar, con ALMENAR BERENGUER Y RIPLEY SORIA $^{66}$, que esto es interesante en lo que afecta especialmente a la prescripción ${ }^{67}$ de la acción para sancionar, ya que el régimen del artículo 189.1 de la LGT tendrá efectos respecto de aquel con quien que se ha iniciado y resuelto el procedimiento sancionador tributario, pero no respecto de los demás presuntos infractores, quienes, en su caso, podrían responder solidariamente ante la Administración si se dan los supuestos recogidos en los artículos 42.1.a) y c) ${ }^{68}$ LGT. Una cosa es que los que hayan concurrido en la realización de una conducta punible puedan ser declarados sujetos infractores, y, de suyo,

suspendida en periodo voluntario sin necesidad de aportar garantías hasta que sean firmes en vía administrativa», por todo ello, hasta que no fuera firme la sanción, al menos en vía administrativa, no debe poder derivarse la responsabilidad (RTEAR Cataluña de 27.05.1998).

${ }^{66}$ HERRERO DE EGAÑA Y ESPINOSA DE LOS MONTEROS, J. M. (2008), pág. 1324; La nueva LGT regula esta transmisión de sanciones en su art. 40.5 con motivo de la sucesión de personas jurídicas: «las sanciones que pudieran proceder por las infracciones cometidas por las sociedades y entidades a las que se refiere este artículo serán exigibles a los sucesores de las mismas, en los términos establecidos en los apartados anteriores, hasta el límite del valor de la cuota de liquidación que les corresponda». En consecuencia, si hay liquidación se transmitirán a los socios hasta la cuota que perciban. Si no la hay, se transmitirán a las personas jurídicas que resulten de la absorción o fusión. En este último caso, la explicación de la transmisión está en la voluntariedad de las nuevas entidades que dentro de un negocio global, aceptan asumir las sanciones. El carácter personalísimo de las infracciones y sanciones...impide la imputación solidaria de sanciones, salvo que la infracción tuviese como base una obligación o deber de cumplimiento conjunto por varios sujetos, lo que tiene un juego limitado en el campo del Derecho Tributario... El caso más próximo a lo que planteamos sería la concurrencia de dos o más contribuyentes en el hecho imponible, aunque en este caso habría que estar a quién de ellos estaba obligado al cumplimiento de las prestaciones. Sólo en el caso de un cumplimiento establecido conjunta y simultáneamente podría hablarse de solidaridad en las sanciones por incumplimiento. Es la línea seguida por la LRJPAC, art. 130 (STC de 12/5/1994). CALVO ORTEGA, R.(2010), págs. 455-456.

${ }^{67}$ Aunque discrepemos, según la jurisprudencia del Tribunal Supremo, el plazo de prescripción del responsable se interrumpiría por las actuaciones integrantes de la vía de apremio contra el deudor-infractor principal (STS 15.12.2011), que sostiene que el inicio o dies a quo del plazo prescriptivo se fundamentaría, por la teoría de la actio nata, desde la fecha en que se pueda ejercitar la acción contra el responsable y no desde la fecha en que se devenga originariamente la liquidación contra el sujeto pasivo.

${ }^{68}$ Aquélla se producirá por cualquier título jurídico que dé lugar a una adquisición derivativa traslativa sobre la titularidad del establecimiento mercantil o explotación principal o del ejercicio de la actividad sin traslación de titularidad de la explotación, no teniendo aplicación práctica la traslación del ejercicio de explotaciones al no tener excesivo rigor conceptual dicho agregado de conceptos. 
respondan solidariamente del pago ${ }^{69}$ de la sanción junto a otros sujetos responsables solidarios no infractores previstos en el art. 42.1.a) y c) ${ }^{70}$ LGT, y otra que lo sean desde el primer momento sin que se tramite un procedimiento sancionador contra ellos. Sólo cuando se inicie, al menos, el procedimiento sancionador respecto de ellos podrá entenderse producida la interrupción de la acción para sancionar respecto de dicho posible sujeto infractor, pero no cuando no exista procedimiento sancionador alguno tendente a su declaración como sujeto infractor, y por ende, como deudor solidario de la sanción. Si pese a su interrupción, prescribiera dicha facultad, cuanto más, dichos presuntos infractores tributarios sólo podrían resultar responsables solidarios de las consecuencias económicas por la vía del art. 42.1.a) y c) LGT, y siempre que se dieren dichos supuestos de hecho $^{71}$, más nunca a título de sujetos infractores, sino como meros garantes $^{72}$ de las consecuencias económicas de otro.

${ }^{69}$ Por normarlo así el art. 181.3 LGT: La concurrencia de varios sujetos infractores en la realización de una infracción tributaria determinará que queden solidariamente obligados frente a la Administración al pago de la sanción.

${ }^{70} \mathrm{La}$ inclusión de este supuesto resulta especialmente criticable, ya que se responde sin que el responsable haya tenido, a priori, nada que ver con el incumplimiento del deudor principal, aunque el legislador presuma que en toda transmisión de ese tipo, exista connivencia entre transmitente y adquirente, sin que quepa prueba en contrario (iuris et de iure), responsabilidad que tampoco se ha limitado la sanción en caso de que no se inste dicha certificación (art. 175.2 LGT), por lo que el responsable podría llegar a responder, cuantitativamente, más allá del valor del propio patrimonio que se le transmite. Merino Jara, I (2006): Acerca de la responsabilidad tributaria, Anuario de la Facultad de Derecho, núm. 24, 2006, pág. 22, nota 25.

${ }^{71}$ Artículo 42 LGT. Responsables solidarios. 1. Serán responsables solidarios de la deuda tributaria las siguientes personas o entidades: a) Las que sean causantes o colaboren activamente en la realización de una infracción tributaria. Su responsabilidad también se extenderá a la sanción.... c) Las que sucedan por cualquier concepto en la titularidad o ejercicio de explotaciones o actividades económicas, por las obligaciones tributarias contraídas del anterior titular y derivadas de su ejercicio. La responsabilidad también se extenderá a las obligaciones derivadas de la falta de ingreso de las retenciones e ingresos a cuenta practicadas o que se hubieran debido practicar. Cuando resulte de aplicación lo previsto en el apartado 2 del artículo 175 de esta ley, la responsabilidad establecida en este párrafo se limitará de acuerdo con lo dispuesto en dicho artículo. Cuando no se haya solicitado dicho certificado, la responsabilidad alcanzará también a las sanciones impuestas o que puedan imponerse. Lo dispuesto en el párrafo anterior no será aplicable a los adquirentes de elementos aislados, salvo que dichas adquisiciones, realizadas por una o varias personas o entidades, permitan la continuación de la explotación o actividad. La responsabilidad a que se refiere el primer párrafo de esta letra no será aplicable a los supuestos de sucesión por causa de muerte, que se regirán por lo establecido en el artículo 39 de esta ley. Lo dispuesto en el primer párrafo de esta letra no será aplicable a los adquirentes de explotaciones o actividades económicas pertenecientes a un deudor concursado cuando la adquisición tenga lugar en un procedimiento concursal.

${ }^{72}$ En todo caso, debe recordarse que la adopción de medidas cautelares frente a los responsables tributarios requerirá, como se indica por parte de la Audiencia Nacional, que existan indicios racionales de que el cobro de la deuda de que se trate pueda verse

(C) UNED. Revista de Derecho UNED, núm. 17, 2015 
En relación con los sujetos omitidos en la relación no exhaustiva del artículo 181.1 de la LGT, concretamos a los siguientes ${ }^{73}$.

A los obligados a realizar pagos fraccionados ${ }^{74}$ se les sujeta por una obligación tributaria autónoma y, por ello, distinta de la del pago de la obligación del pago de la obligación principal (art. 23 LGT), por lo que cuando no se realice o se realice incorrectamente, o se dejará de ingresar o se incumplirá la obligación de presentar una declaración si su resultado es negativo o cero ${ }^{75}$. En ambos casos, tales conductas se tipifican en los artículos 191 y 198 de la LGT, conductas que no se regularizan por la presentación sin requerimiento de la autoliquidación final, donde se subsumen los pagos fraccionados no efectuados.

Para los obligados a repercutir ${ }^{76}$, supuesto que se encuentra en el Impuesto sobre el Valor Añadido, su obligación debiera considerarse

frustrado o gravemente dificultado y las mismas se encuentren debidamente motivadas al notificarse a aquéllos, requisitos todos ellos que, a juicio del referido órgano jurisdiccional, concurren en el asunto enjuiciado. Carreras Manero, OLGA (2014): «La adopción de la medida cautelar de embargo preventivo de créditos frente al responsable por transmisión de una actividad económica. A propósito de la Sentencia de la Audiencia Nacional (Sala de lo Contencioso-Administrativo, Sección 7. ${ }^{a}$ ) de 13 de mayo de 2013», Aranzadi, JT 2013/1083, Revista Quincena Fiscal núm.. 6/2014. BIB 2014\797.

${ }^{73}$ OCHOA incluye entre los omitidos, el supuesto de herederos por el incumplimiento de las obligaciones del fallecido cuyo cumplimiento deba de efectuar, v.gr. el de presentar la declaración del finado ex art. 96.7 TRLIRPF. DÍEZ OCHOA, J. M.(2006), pág. 65.

${ }^{74}$ En el IS, están obligados a realizar pago a cuenta, todos los sujetos pasivos (art. 128.1 LIS); En el IRPF, únicamente los contribuyentes que ejerzan actividades económicas (art. 99.7 LRIFP), con dos excepciones, los agricultores, ganaderos o titulares de actividades forestales y los profesionales, cuando en el año anterior, al menos el 70 por 100 de sus ingresos han quedado sometidos a retención o ingreso a cuenta. AA. VV. (Coord. PELÁEZ MARTOS, J. M. ${ }^{a}$ ) [2007], pág. 213; Los pagos fraccionados constituyen una modalidad de pago a cuenta caracterizada, frente a las retenciones e ingresos a cuenta, porque el obligado a realizarlos es el propio contribuyente perceptor de la renta...se encuentran obligados a efectuar pagos fraccionados los contribuyentes que desarrollen actividades económicas [con las excepciones de las actividades previstas en el art. 109, apartados $2 .^{\circ}, 3 .^{\circ}$ y $4 .^{\circ}$ RIRPF]...mientras que el pago fraccionado correspondiente a rendimientos obtenidos por entidades en régimen de atribución de rentas deberá efectuarlo de forma individual cada socio, comunero o partícipe, en la proporción que le corresponda según su participación en los beneficios de la entidad (art. 112 RIPRF). PÉREZ ROYO, F. (Dir) (2010): Curso de Derecho Tributario. Parte Especial, Tecnos, Madrid, págs. 309-310.

${ }^{75} \mathrm{El}$ actual Reglamento del IRNR establece en el artículo 18 tanto la retención como el ingreso a cuenta, pero esta previsión reglamentaria tiene una dudosa base legal. SERRANO ANTÓN, F.(2006): Fiscalidad Internacional, CEF, Madrid, pág. 441.

${ }^{76}$ Aunque el obligado a soportar la repercusión -persona o entidad a quien, según la ley, se deba repercutir la cuota tributaria-, es, salvo que la ley disponga otra cosa, el destinatario de las operaciones gravadas, el repercutido no está obligado al pago frente a la Administración tributaria pero debe satisfacer al sujeto pasivo el importe de la cuota repercutida (art. 38.3 LGT), sin perjuicio de que la relación obligatoria que une al contribuyente sujeto pasivo del tributo y al repercutido sea una relación entre particulares (art. 24.2 LGT). FERREIRO LAPATZA, J. J.(2006), págs. 443-444; El objeto de la repercusión 
formal, no obstante no lo efectúa así el artículo 29 de la LGT, por lo que nos genera dudas su naturaleza, máxime cuando el artículo 24 LGT califica de obligaciones entre particulares las que se generan como consecuencia de actos de repercusión, de retención o de ingreso a cuenta, motivo por el que el obligado a repercutir debiera ser calificado, al menos teóricamente, de sujeto infractor si incumple su obligación de retener, si bien, dentro del grupo general de los infractores de obligaciones tributarias formales. En este orden de cosas, y dada la falta de tipo específico que contemple incumplimientos específicos en torno a la repercusión, debemos entender que no repercutir o repercutir de modo incorrecto originará infracción por los artículos 191, 193, 194, 195.1, 199, 200 y 201, etcétera.

Los obligados a soportar la repercusión ${ }^{77}$ tampoco se ven afectados por tipo alguno infractor de la Ley del IVA, al no ser estas situaciones

es exclusivamente la cuota tributaria que debe satisfacer a la Administración el sujeto pasivo-repercutidor, pero no cualquier otra obligación accesoria contraída por éste (interés de demora o recargo por declaración extemporánea)

${ }^{77}$ Esta figura ha sido objeto de opiniones doctrinales dispares, que van desde la calificación jurídico-privada de aquella relación, hasta su consideración como obligación tributaria (hoy resuelta por el art. 24.2 LGT) y la del repercutido como verdadero contribuyente en sentido material (obligado a contribuir). En cualquier caso, es mayoritaria la tendencia a destacar el carácter tributario de la repercusión, sobretodo a raíz de su calificación normativa como actuación reclamable en vía económico-administrativa. BAYONA DE PEROGORDO, J. J. y SOLER ROCH, M. T.(1999): Materiales de Derecho Financiero, Compás, Alicante, pág. 260; La traslación (tributaria) exige un hecho jurídico concreto cuyos sujetos son contribuyentes y tercero repercutido: la entrega de un bien, la prestación de un servicio y la adquisición de un producto. Son hechos que se inscriben en una relación mercantil o civil y que tienen esa efectualidad de obligar a realizar la traslación al contribuyente y a soportarla al tercero repercutido. Lo importante de este hecho es destacar sus sustantividad...La repercusión tributaria es una técnica utilizada por el legislador en determinados tributos indirectos (v.gr. IVA, IIEE) para que el impuesto sea pagado por el consumidor final inmediatamente o a través de sujetos intermedios, según las fases económicas o jurídicas de los procesos de producción y comercialización de bienes y servicios. Esta finalidad legislativa justifica que la traslación sea obligatoria para el contribuyente y para el sujeto repercutido.... La traslación se limita únicamente a la cantidad derivada de la aplicación del impuesto al hecho propio de la traslación; en otras palabras, se limita a la cuota (obligación tributaria estricta) y no a otros elementos de la deuda tributaria...En consecuencia no se extiende a la situación jurídica del contribuyente que debe pagar el impuesto y realizar los deberes fiscales y que conserva su posición con independencia de la traslación y, obviamente su responsabilidad. La traslación es un hecho jurídico formal. Debe ser hecho en un documento normalizado (factura)...El pago hecho por el tercero repercutido extingue la traslación en su vertiente material y, obviamente, principal sin perjuicio de los deberes de conservación y exhibición documental...El tercero repercutido tiene la condición de obligado tributario, ya que está obligado a realizar una prestación tributaria esencial como es el pago de la obligación misma, junto con deberes documentales anexos. La LGT califica como obligados tributarios tanto a los sujetos que deben repercutir como a los que deben soportar la repercusión. CALVO ORTEGA, R. (2010), págs. 189-190; La expresión «contribuyente de hecho», utilizada por algún sector

(C) UNED. Revista de Derecho UNED, núm. 17, 2015 
en las que haya obligación de soportar la repercusión. Esta obligación tiene el carácter de obligación entre particulares de las prevenidas en el artículo 24 de la LGT, y no tiene tipo específico en la LGT, por lo que no serán sujetos infractores por no soportar la repercusión o soportarla indebidamente, sino por las acciones tipificadas que generen las consecuencias de sus acciones ${ }^{78}$.

En la misma situación que los obligados a soportar repercusión se encuentran los obligados a soportar la retención y los obligados a soportar los ingresos a cuenta.

Los beneficiarios de supuestos de exención, devolución o bonificaciones tributarias, cuando no tengan la condición de sujetos pasivos, podrían ser sujetos infractores de los tipos de los artículos 193, 194, 195 y 199, aunque por lo exigido por el artículo 35 LGT, que no sean sujetos pasivos, va a hacer que se haga difícil en la práctica que puedan ser sujetos infractores ${ }^{79}$.

La LGT no contempla la autoría del representante voluntario ${ }^{80}$, aunque no parece que la solución pueda diferir de la prevista para el

doctrinal, sólo puede ser, en mi opinión, correctamente empleada, ya en general, para aludir, repito, a aquellas personas que soportan, en términos económicos, la carga económica derivada del tributo sin que ninguna norma jurídica les obligue a ello. Es dudoso, siempre en mi opinión, que tal expresión pueda emplearse con utilidad en el análisis jurídico del tributo, como no sea para hacer ver la intención de la Ley e interpretar ésta de acuerdo con ella. Y aún con este fin, con el fin de hacer ver las personas que la Ley quiere que resulten realmente gravadas, parece más conveniente utilizar los términos más usuales de la terminología económico-financiera para referirse a la posible incidencia o traslación del impuesto que emplear expresiones como la de "contribuyente de hecho», de significado impreciso, que pueden confundirse con otros términos a los que el ordenamiento atribuye otro significado muy preciso y determinado. En cualquier caso,...la expresión contribuyente de hecho no debe emplearse, ....para hacer referencia a una persona que está obligada por una norma jurídica a realizar un pago. FERREIRO LAPATZA, J. J.(2006), págs. 404-405; En todo caso, es importante resaltar que la relación con la Hacienda Pública se establece sólo con el contribuyente formal, el obligado a repercutir. Como aclara la propia LGT (art. 38.2.2. ${ }^{\circ}$, in fine) el repercutido no está obligado al pago frente a la Administración tributaria, ni siquiera en el caso de que el contribuyente no haya practicado repercusión ni ingresado el tributo. PÉREZ ROYO, F.(2009), pág. 166.

78 El tratamiento que el sujeto perceptor de la renta debe dar al ingreso a cuenta, es diferente según que se produzca o no la repercusión: si no le repercuten el ingreso a cuenta, el contribuyente incluirá en la base imponible la valoración de la correspondiente retribución más el ingreso a cuenta, y deducirá de la cuota del impuesto el importe del mismo, junto a las retenciones y pagos fraccionados; si le repercuten ingreso a cuenta, únicamente incluirá en la base imponible la valoración de la retribución, sin añadir el ingreso a cuenta, que, por otra parte seguirá siendo deducible de la cuota del impuesto. AA.VV. (Coord. PELÁEZ MARTOS, J. M. ${ }^{\text {) }}$ (2007), pág. 219.

${ }^{79}$ LAMOCA PÉREZ, C.(2005), pág. 49.

${ }^{80}$ Sea o no necesaria dicha representación, subsisten argumentos relacionados con el principio de personalidad de la sanción. Ello resulta especialmente claro en los supuestos de representación de sujetos pasivos no residentes, obligados en el concreto ámbito del IRPF (art. 10 RD Lg. 5/2004), por lo que también deberá ser considerado responsable direc- 
representante legal ${ }^{81}$. En todo caso habrá que tener en cuenta los términos en los que se encuentra conferida la representación, puesto que si le corresponde al representante el cumplimiento de los deberes y obligaciones tributarias, a él debe imponérsele la sanción derivada de la infracción cometida ${ }^{82}$. Podemos distinguir dos supuestos, uno de autoría mediata ${ }^{83} \mathrm{en}$ el que el representado es el instrumento, siendo sujeto infractor el representante. Y otro, en el que el representante es el instrumento para cometer el representado la infracción, siendo este último el infractor.

to de las consecuencias derivadas del eventual incumplimiento de las correspondientes obligaciones. Tampoco puede admitirse, sin más, que la responsabilidad por infracciones quede a cargo del representado, en los restantes supuestos de representación voluntaria no necesaria, porque también en tales casos la conducta infractora habrá sido realizada por el representante y sus consecuencias no pueden hacerse recaer sobre el representado sin violentar el principio de personalidad de la sanción. En consecuencia, salvo que el representado pueda ser considerado causante o colabore activamente en la realización de la infracción, las consecuencias de la conducta ilícita han de quedar a cargo de quién la realiza, aunque sea en virtud de una relación de representación voluntaria, con independencia de que pueda apreciarse o no negligencia en la actitud del sujeto representante, por que la concurrencia de dicho elemento es irrelevante en quien ha decidido actuar en sus relaciones con la Hacienda a través de representante. ZORNOZA PÉREZ, J. J.(1992), págs. 190 y 191. De otro parecer es PÉREZ ROYO, F.(1986), pág. 291; La LGT sólo se refiere a la representación legal; si se tratase de la voluntaria o negocial, no es conveniente adelantar soluciones a priori, habrá que examinar en cada caso la participación de cada uno en la infracción cometida. Una infracción no sería propiamente una actuación fuera de los límites del mandato, sería un incumplimiento de éste, pues el mandato no puede consistir en defraudar a Hacienda, ya que el art. 1275 del Código Civil establece la nulidad para los contratos que no tenga una causa o fin lícitos. MARTÍNEZ LAGO, M. A. et alii (1991), pág. 30; En el caso del representante voluntario habrá que estar a la casuística pero será difícil obviar al menos una culpa in eligendo o in vigilando por parte del obligado tributario, que habilite la imposición de la sanción. En cualquier caso, el art. 181 LGT no considera al representante voluntario o al asesor del obligado tributario como sujeto infractor, ni es titular de obligaciones propias que puedan ser incumplidas, por lo que no podrá dirigirse acción sancionadora alguna contra el representante o asesor, sin perjuicio de su posible responsabilidad al amparo del art. 42.1.a) LGT. HERRERO DE EGAÑA Y ESPINOSA DE LOS MONTEROS, J. M. (coord.) (2008), pág. 1323; También lo echa en falta, el representante voluntario y los herederos, por el incumplimiento de las obligaciones del fallecido cuyo cumplimiento tenga que efectuar el heredero. AA. VV. (Coord. PELÁEZ MARTOS, J. M. ${ }^{\text {) }}$ (2007), pág. 1015.

${ }^{81}$ PÉREZ ROYO, F. (1986), pág. 182. ZORNOZA PÉREZ, J. J.(1992), pág 190; ZABALA RODRÍGUEZ FORNÓS, A. (1989): «La representación voluntaria en el ámbito de la Inspección de los Tributos», CISS Comunicación, núm. 68, pág. 52.

${ }^{82}$ MARTÍN DÉGANO, I. (2001): «La responsabilidad del asesor fiscal derivada de su participación en el delito de defraudación y en la infracción tributaria», CaT Monografías, núm. 1, pág. 22; En caso de desatención a requerimientos por el representante voluntario autorizado la infracción por el art. 203 LGT a él le sería imputable, lo contrario significaría trasladar la conducta infractora a quien no ha participado en la misma. RAMÓN DE LA POZA, L. M.(2005), pág. 31.

${ }^{83}$ No se nos escapa que, si ya es difícil que la práctica administrativa y judicial admitan la existencia de supuestos de coautoría en las infracciones tributarias, la apreciación de una autoría mediata es poco menos que una quimera. Rodríguez Márquez, J.(2003). 
Debemos mentar otros supuestos de autoría, como las de mera complicidad-como se dan en los artículos 195 a 197 LGT-, en que la participación quedaría impune, pues el artículo 181 de la LGT considera autor al que realice las acciones u omisiones tipificadas como infracciones ${ }^{84}$. Así, en la medida en que no se realicen actos de ejecución material, la complicidad ${ }^{85}$ no sería sancionable. Tampoco el encu-

${ }^{84}$ HERRERA MOLINA, P. M.(1997), pág. 706.

${ }^{85}$ Las posiciones doctrinales en cuanto a la responsabilidad penal del asesor pueden clasificarse en extremas y distintivas. Las extremas son dos. Un sector que estimo muy minoritario considera..que el asesor jurídico no responde nunca penalmente por cuanto obra en el ejercicio de su profesión, lo que daría lugar siempre a la causa de justificación de obrar en el ejercicio de un derecho (art. 20.7CP). En este mismo punto, aunque partiendo de premisas distintas, debe situarse...la postura-de Luís ALONSO GONZÁLEZque considera éste no responde penalmente dado que no comete infracción tributaria alguna y el delito fiscal se configura como una ley penal en blanco. Ambos posturas deben criticarse por cuanto la teoría de la participación en Derecho Penal es una construcción absolutamente autónoma que no puede vincularse a la infracción de deberes extrapenales por parte del sujeto en cuestión -las leyes penales en blanco son accesorias del Derecho Administrativo en cuanto a los tipos de autoría, pero los tipos de participación son tipos cerrados y comunes-. El sector opuesto, entiende el asesor siempre responde de que su actuación informadora da lugar a una contribución o reforzamiento accesorio de la conducta delictiva del autor, redundando en la producción del resultado típico del delito, ello, naturalmente, siempre que exista dolo, en cualquiera de sus formas, esto es, que el sujeto sepa o tenga por probable que su intervención asesora va a dar lugar a la comisión del delito por parte del asesorado. Dentro de estas doctrina distintiva podemos distinguir tres posturas, una que admite la posibilidad de la concurrencia de una causa de justificación en la conducta del asesor, pero sólo si se dan determinados presupuestos. Otras, por la que la responsabilidad del asesor exigiría que éste obrara con dolo directo, esto es, sabiendo de modo seguro que su conducta habría de dar lugar a que el asesorado realizara el hecho delictivo, no siendo suficiente que el asesor lo considerara probable en términos de dolo eventual. Y una última postura, que entiende que las conductas de asesoramiento no pueden ser constitutivas de participación punible si se mantienen en el ámbito de lo que puede denominarse intervención neutral, de modo que no van más allá del standard de licitud establecido para la posición jurídica del asesor. SILVA SÁNCHEZ, J. M. ${ }^{a}(2005)$ : El nuevo escenario del delito fiscal en España, Atelier, Barcelona, págs. 79-98; En ese sentido, (al comentar las conductas 'neutrales')no parece consistente el mensaje de que el deber de abstenerse de favorecer desaparezca en casos de duda, sospecha o probabilidad y en cambio, no suceda lo mismo cuando haya un conocimiento seguro o prácticamente seguro. Y ello porque, si no existe el deber de informarse ante la situación, tampoco podrá admitirse su relevancia cuando la información se posea por el sujeto... El profesional que se mueve estrictamente en el marco de su actividad laboral se comporta estructuralmente como un omitente, que simplemente deja o no impide que el autor le sustraiga el instrumento necesario para cometer el delito. Tan sólo cuando pueda afirmarse la infracción de un deber específico o bien cuando su conducta deje de moverse en el ámbito de lo estrictamente profesional y pase a ser parte integrante del hecho mediante una adaptación específica al mismo podrá hablarse de intervención penalmente relevante... Si el asesor se limita a aconsejar o recomendar una determinada actuación para lograr unos determinados fines cuya consecución es lo que constituye su razón de ser, no existirá complicidad aún cuando se conociera que el asesorado podría cometer un delito posteriormente adoptando el consejo técnico... Si el abogado informa al cliente sobre la presencia de líneas jurisprudenciales contradictorias o apela a razones fundadas para discrepar de una juris- 
bridor $^{86}$, entendido como aquel que conociendo la comisión de una infracción tributaria por parte de otro u otros no pone en conocimiento de los órganos administrativos competentes la realización de esos hechos, resultaría sancionable, pues no realiza materialmente acciones u omisiones ilícitas, no es autor, ni causante ${ }^{87}$ ni colaborador de la infracción, a más de por expreso deseo del legislador ex art. 182.3 LGT. Entendemos que dicha consideración personalísima debería de atribuirse a la conducta y sanción impuesta a la persona jurídica quien, como sujeto capaz, no debe poder transmitir a sus legítimos herederos -sucesores- su responsabilidad infractora, ni tampoco las consecuencias económicas que de aquélla deriva.

Por último, los sucesores, al igual que los responsables ${ }^{88}$, son supuestos diferentes del de los sujetos infractores, al ser, cuanto más, meramente res-

prudencia consolidada en el caso concreto, no incurrirá en responsabilidad penal aunque el hecho llevado a cabo por el cliente resulte finalmente calificado como delictivo por un tribunal...el asesor profesional no es ni un gatekeeper ni un garante. Esto es, por un lado, no existen deberes de abstención específicos derivados de una posición de especial relevancia institucional (como sí ocurre, por ejemplo, en el caso de los notarios ROBLES PLANAS, R.(2008): «Riesgos penales del asesoramiento jurídico», Diario La Ley, núm. 7015, Sección Doctrina, 18 Sep. 2008, Año XXIX, Ref. D-263, págs. 3,7-8,11,13-14.

${ }^{86}$ GUERRA REGUERA, M.(1999): "Consideraciones en torno al artículo 38 de la LGT», Tribuna Fiscal (TF), núm. 105, pág. 47.

${ }^{87}$ Según algún autor, dicho precepto no incluiría formas de participación omisivas, a más de exigir intencionalidad, y el carácter decisivo y determinante del resultado ilícito -lo que deberá determinarse en el acto de derivación-, cuyo onus probandi recaerá en la Administración Tributaria. MARTÍN FERNÁNDEZ, J. (2005): Responsabilidad del profesional tributario como asesor del contribuyente, Rev. De la Asociación profesional de Técnicos Tributarios de Cataluña y Baleares, núm. 23, diciembre 2005, págs. 26-33. En contra, admitiendo que la participación sea por acción u omisión, Merino Jara, I (2006): Acerca de la responsabilidad tributaria, Anuario de la Facultad de Derecho, núm. 24, pág. 20.

${ }^{88}$ La ley llama responsable del tributo, sin embargo, a un sujeto distinto del contribuyente e incluso del sustituto.... Tiene su propio hecho generador de responsabilidad (que no es obviamente el hecho imponible) y que responde a razones y fundamentos muy diversos....responsabilidad por razones estrictamente de garantía..., responsabilidad por realización de un ilícito, supuestos en los que ésta adquiere la naturaleza de una sanción específica sustituyendo así a la sanción genérica que corresponda por la comisión de una infracción. Así por ejemplo, personas que sean causantes o colaboren en la realización de una infracción tributaria; determinados profesionales que no realicen las gestiones necesarias por negligencia o mala fe para el cumplimiento de obligaciones de terceros cuando estén obligados expresamente a ello (arts. 42 y 43 LGT); sociedades integrantes de un grupo consolidado por las infracciones cometidas en este régimen de tributación; cooperación o colaboración en la ocultación maliciosa de bienes con la finalidad de impedir su traba; incumplimiento culposo de las órdenes de embargo; cooperadores en el levantamiento de bienes (art. 42 LGT), etc. Este tipo de responsabilidad derivado de una infracción es, probablemente, el que mayores problemas plantea. Si la deuda la paga el responsable y la repetición no es posible estaremos ante un supuesto en que el contribuyente ha quedado liberado, siendo éste quien ha manifestado la capacidad económica. Si lo hace el contribuyente quedará sin sanción la infracción cometida por el responsable en el caso de que se considere su comportamiento como ilícito. En resumen, la incidencia tributaria definitiva puede llevar a una situación injusta en relación con un sujeto determinado. CALVO ORTEGA, R.(2010), págs. 179-181.

(C) UNED. Revista de Derecho UNED, núm. 17, 2015 
ponsables $^{89}$ de las de las consecuencias económicas de la infracción tributaria -esto es, la sanción-, exclusión hecha de herederos ${ }^{90}$ y legatarios de las personas físicas (artículo 182.3 LGT) a quienes no se les puede transmitir por ningún título la sanción ya impuesta, por el propio carácter personalísimo de la conducta infractora y de sus consecuencias, y al no haber tenido, seguramente, ninguna relación con la actuación reprobada y sancionada.

Habiendo dejado un tanto perfilados los supuestos actores, podemos concluir que los sujetos autores de la infracción tributaria, o presuntos infractores tributarios, serán aquellos respecto de los que cabrá que pueda darse alguna de las causas de extinción de la responsabilidad -infractora- dimanante de la infracción tributaria cometida.

\section{CAPACIDAD INFRACTORA DE LAS ENTIDADES CARENTES DE PERSONALIDAD JURÍDICA}

El artículo 35.4. ${ }^{\circ}$ LGT contempla que «tendrán la consideración ${ }^{91}$ de obligados tributarios, en las leyes en que así se establezca ${ }^{92}$, las herencias yacentes ${ }^{93}$, comuni-

${ }^{89}$ Sin embargo, algún autor los califica como posibles sujetos infractores, junto a los beneficiarios en supuestos de exención, devolución o bonificaciones tributarias -cuando no tengan la condición de sujetos pasivos-. DELGADO GARCÍA, A. M. a; OLIVER CUELLO, R.(2008), pág. 289.

${ }^{90}$ Sin embargo, los herederos serán sancionados si no declaran la renta del fallecido (RTEAC 6.06.2003). La conducta de quien no declara el IRPF de las rentas del cónyuge fallecido es sancionable (STS 24.01.1996).

${ }^{91} \mathrm{Ni}$ la Ley de 1963, ni la actual dijeron nunca que tales entes sin personalidad son sujetos pasivos. Con toda intención y claridad dijeron y dicen que las leyes en que así se considere conveniente tales entes pueden ser considerados como si de un sujeto pasivo se tratara. FERREIRO LAPATZA, J. J.(2006), pág. 369.

${ }_{92}$ En el IVA, el art. 84.3 de la Ley 37/1992, les atribuye la condición de sujeto pasivo del citado impuesto; En el IRPF no tienen la condición de sujeto pasivo (contribuyente).....sin embargo, sí que se les atribuye la condición de obligado tributario en concepto de obligado a practicar retenciones e ingresos a cuenta (art. 99.2 Ley 35/2006); En el Impuesto sobre Sociedades, no tienen la consideración de contribuyentes. Sin embargo, el art. 128.1 LIS establece que...estarán obligadas a retener o a efectuar ingresos a cuenta en concepto de pagos a cuenta...La determinación de estos obligados tributarios se regulará en todo caso por ley. Por tanto, su posición no podrá ser alterada por los actos o convenios que éstos celebren con los particulares (art. 17.4 LGT). AA.VV. (Coord. PELÁEZ MARTOS, J. M. ${ }^{2}$ ), pág. 208; El TRLHL (RDLg. 2/2004), lo recoge como sujeto pasivo del Impuesto sobre Bienes Inmuebles en el art. 63.

${ }^{93}$ Por herencia yaciente se entiende aquella que todavía no se ha producido la aceptación por los herederos, que puede ser expresa o tácita y cuyos efectos se retrotraen al momento mismo de la muerte del causante. Respecto del Impuesto de Sociedades (IS) no pueden considerarse sujetos pasivos, porque carecen de personalidad jurídica y tributan en régimen de atribución de rendimientos, tampoco son sujetos del IRPF, en el Impuesto de Actividades Económicas (IAE) tienen reconocida la personalidad siempre que realicen en territorio nacional cualquiera de las actividades que supongan mero ejercicio de actividad económica. Lo mismo ocurre en el Impuesto de Bienes Inmuebles (IBI) cuando sean propietarias de inmuebles o titulares de un derecho real de usufructo o de superficie sobre inmuebles. En el Impuesto sobre el Valor Añadido (IVA), se les considera sujetos pasivos cuando realicen operaciones sujetas al impuesto, mientras que en el 
dades de bienes ${ }^{94}$ y demás entidades ${ }^{95}$ que, carentes de personalidad jurídica ${ }^{96}$,

Impuesto sobre Transmisiones Patrimoniales y Actos Jurídicos Documentados (ITPAJD) y en el Impuesto sobre Sucesiones y Donaciones (ISD) no se les enumera como sujetos pasivos. MUÑOZ BAÑOS, C.(1999), págs.36 a 38; Mientras no se produzca la aceptación, la herencia estará en administración. Hacemos esta precisión para diferenciarla de otra figura que se da también en el derecho de sucesiones, que es la de la comunidad hereditaria, o sea, la integrada por los herederos que ya aceptaron la herencia pero aún no la repartieron o dividieron. La LGT no menciona este supuesto, aunque cabe ciertamente entender que el mismo se encuentra comprendido en el de comunidad de bienes.... En ambos casos estamos ante supuestos de caudal hereditario o herencia en administración, pero respondiendo a circunstancias muy diversas. PÉREZ ROYO, F. (2009), págs. 156-157.

${ }^{94}$ Existe una comunidad de bienes cuando la propiedad de una cosa o un derecho pertenece pro indiviso a varias personas. En el IS y en el IRPF no son sujetos pasivos, pero están sometidas al régimen de atribución de rendimientos que se imputarán a los comuneros. En el IAE, IBI y en el IVA el sujeto es la comunidad. Las devoluciones por IVA corresponden a la comunidad y nunca a los comuneros (DGT 1 de octubre de 1986). No se las considera sujetos en el ITPAJD ni en el ISD. MUÑOZ BAÑOS, C.(1999), págs. 38 a 39.

${ }^{95}$ Las «demás entidades» del art. 33 LGT son las siguientes: Fondos de Inversión Mobiliaria o Inmobiliaria; Fondos de Pensiones; Fondos de Titulación; Fondos de CapitalRiesgo; Uniones Temporales de Empresas; Asociaciones de hecho de carácter temporal; y las Sociedades irregulares, que son aquéllas que no habiendo inscrito en el Registro Mercantil la escritura de su constitución pueden realizar sin embargo operaciones con efectos frente a terceros. No se incluyen en este grupo de entidades las Agrupaciones de Interés Económico (AIE), ya que tienen personalidad jurídica, ni tampoco a las sociedades civiles cuando la tengan, porque cuando carezcan de la misma tributan en régimen de atribución de rendimientos. MUNOZ BAÑOS, C.(1999), págs. 39 y 40.

${ }_{96}$ El texto de la Ley permite una interpretación...que se basa en la viaja tesis de la capacidad tributaria distinta (así Giannini, Pugliese, Hensel, Bañón, etc) o en la ruptura con la doctrina común y generalmente aceptada sobre capacidad en todo el ordenamiento tributario. Por ello parece necesario insistir en que la doctrina no sólo tradicional (Vicente Arche, Cortés, Sáinz de Bujanda, basándose en la tesis de Berliri) sino todavía hoy absolutamente mayoritaria, mantiene la tesis de que sólo son sujetos de derecho las personas físicas y jurídicas FERREIRO LAPATZA, J. J.(2006), pág. 368; Por el contrario CALVO ORTEGA estima que la ley fiscal no interviene de manera caprichosa y exorbitante para la atribución de la personalidad. La personalidad exige dos requisitos, una cierta organización y atribución legal. Nada impide que la ley tributaria realice esta declaración sobre un entramado de relaciones cohesionadas con efectos limitados a su propio ordenamiento. ... Concluye que el anterior art. 33 LGT trata un planteamiento didáctico y no normativo, ya que la LGT no atribuye tal personalidad, limitándose a indicar que pueden hacerlo otras leyes, v.gr. IVA, I. Sociedades.. CALVO ORTEGA, R.(2001): Curso de Derecho Financiero. Derecho Tributario. Parte General, Civitas, Madrid), pág. 166; el CP ha optado por establecer una suerte de primer filtro de imputabilidad consistente en el criterio de la personalidad jurídica (privada). Aquellos entes que no gocen de la misma se ven relegados al régimen del art. $129 \mathrm{CP}$ que, en su nueva redacción, contiene unos criterios de imputación notablemente más laxos que el anterior, puesto que única y exclusivamente hace referencia a que se impondrán las sanciones correspondientes a dicho precepto «motivadamente». Por tanto, empresas, organizaciones, grupos o cualquier otra clase de entidades o agrupaciones de personas que carezcan de personalidad jurídica quedan excluidas del ámbito de aplicación del art. 31 bis. No obstante, la similitud de las sanciones a imponer por vía del art. $129 \mathrm{CP}$ y del art. 31 bis y la gravedad de las mismas obligan, cuando menos, a considerar la posibilidad de aplicar requisitos similares de imputación en ambos casos, puesto que una diferencia sustancial de trato encuentra difícil justificación en la

(C) UNED. Revista de Derecho UNED, núm. 17, 2015 
constituyan una unidad económica ${ }^{97} \mathrm{o}$ un patrimonio separado susceptibles de imposición ${ }^{98} »$.

mera personalidad jurídica. GÓMEZ-JARA DÍEZ, C.(2008): «La incidencia de la autorregulación en el debate legislativo y doctrinal sobre la responsabilidad penal de las personas jurídicas», en Curso Superior Universitario en Derecho Penal Económico. Un diálogo entre Jueces, fiscales, abogados y profesores, Cátedra de Investigación Financiera y Forense, KPMG, URJC, julio 2008, pág. 2; El legislador ha establecido un doble sistema de responsabilidad penal de los entes colectivos: en el art. 31 bis CP y en el art. 129 CP. El art. 31 bis $\mathrm{CP}$ se recoge la responsabilidad penal de las que estrictamente sean personas jurídicas (22), dejando subsistente el art. $129 \mathrm{CP}$ para aquellas empresas, organizaciones, grupos o cualquier otra clase de entidades o agrupaciones de personas que carezcan de personalidad jurídica. Es decir, que los sujetos imputables del art. 31 bis son personas jurídicas en el sentido de lo dispuesto en el art. 35 CC, mientras que la responsabilidad ex art. 129 CP será aplicable, por ejemplo, a los grupos de empresas, sociedades civiles, agrupaciones de interés económico, y uniones temporales de empresas (UTE), entre otras... Hay que tener en cuenta que a los entes colectivos sin personalidad jurídica se les podrá imponer las consecuencias accesorias del art. $129 \mathrm{CP}$ por todo el catálogo de delitos previsto para las personas jurídicas (129.2 CP) y por los que expresamente tengan previsto sólo las consecuencias accesorias [delitos relativos a la manipulación genética (art. 162), alteración de precios en concursos y subastas públicas (art. 262), delitos contra los trabajadores (art. 318) y delito de falsedad de moneda (art. 386)]. BACIGALUPO SAGESSE, S.(2011): «Los criterios de imputación de la responsabilidad penal de los entes colectivos y de sus órganos de gobierno (arts. 31 bis y 129 CP)», Diario La Ley, Madrid, n. ${ }^{\circ}$ 7541, Sección Doctrina, 5 Ene. 2011, págs. 4 y 8; Tratándose de entidades del artículo 35.4 de la Ley 58/2003, de 17 de diciembre, General Tributaria, las actuaciones de comprobación o investigación que tengan por objeto examinar el adecuado cumplimiento de sus obligaciones tributarias, incluidas las de carácter formal, se desarrollarán con quien tenga su representación de acuerdo con lo establecido en el artículo 45.3 de dicha ley. Las liquidaciones que, en su caso, procedan se practicarán a nombre de la entidad, sin perjuicio de la responsabilidad solidaria de los partícipes, miembros o cotitulares de dichas entidades.[La representación de una persona o entidad por otra, puede venir impuesta por la ley -representación legal-, y ser por tanto necesaria, o bien ser un acto libre y voluntario del interesado -representación voluntaria-.] AA. VV. (Coord. PELÁEZ MARTOS, J. M. ${ }^{a}$ ) (2007), pág. 111.

${ }^{97}$ Unidad económica supone como reiteradamente ha señalado la doctrina tributarista (por todos Sáinz de Bujanda), además de un cierta base patrimonial separada, una cierta organización que le permita actuar en el tráfico jurídico de forma unitaria y separada también de las actividades económicas de sus partícipes. Por patrimonio separado puede entenderse (siguiendo a Castán, Díez Picazo y Gullón) aquel patrimonio que con uno o varios titulares la Ley autoriza u ordena colocar al servicio de un determinado fin, en virtud del cual se delimitan en alguna forma las deudas y responsabilidades, así como las facultades de sus titulares. Aquel patrimonio que posee- según Falcón- una cierta e identificable autonomía funcional que limite de algún modo las facultades de los partícipes. FERREIRO LAPATZA, J. J.(2006), pág. 371.

98 «Debe admitirse para su explicación que el ordenamiento jurídico puede incorporar esquemas de calificación de agrupaciones de personas distintas del esquema de la personalidad jurídica, considerándolas unitariamente y haciéndolas centro de imputación de intereses. Así ocurre, en efecto, en el propio Código Civil respecto a las comunidades de bienes y a las herencias yacentes, citadas por el transcrito precepto de la LGT,... En tales casos, la LGT no ordena, sin embargo, que sean obligados tributarios en todo caso, sino que meramente contiene la previsión genérica de que las leyes propias de cada tributo podrán considerarlos como tales. Y efectivamente, así ocurre en determinados tributos respecto a ciertos entes sin personalidad, mientras que en otros se prescinde de esta posibilidad para gravar 
Por tanto dichas entidades, en la medida que así aparezcan normativamente previstas como obligados tributarios tendrán capacidad para ser sujetos infractores, si bien no faltan opiniones favorables ${ }^{99}$ a que sean considerados como sujetos infractores los comuneros o los participes para respetar de este modo la responsabilidad por conducta personal culposa.

La LGT hace una concreción de la subjetividad tributaria en las personas naturales o jurídicas. En principio, la declaración es correcta, toda vez que la personalidad jurídica es un atributo de las personas físicas, y de las jurídicas que han cumplido los requisitos exigidos por las diferentes leyes para obtener la citada personalidad. Sin embargo, allí donde exista una cierta organización (patrimonio, relaciones jurídicas, titularidades patrimoniales, órganos cohesionados en torno a una actividad y una permanencia suficiente) puede haber el sustrato necesario para la atribución de capacidad para la comisión de infracciones tributarias. Será necesario que una ley así lo establezca expresamente, y, en nuestro caso, la ley fiscal no interviene de manera caprichosa y exorbitante para la atribución de la cualidad que examinamos, donde siempre habrá una realidad organizativa ${ }^{100}$. Así las cosas, nada veta que la ley tributaria realice esta declaración sobre un entramado de relaciones cohesionadas con efectos limitados a su propio ordenamiento, lo que llevará necesariamente a determinar toda la efectualidad jurídica que sea precisa para permitir que se imponga una infracción tributaria, eso sí, limitada a la realización de un determinado supuesto de hecho, circunstancia en donde la

directamente a cada miembro integrante del ente sin personalidad. Lo significativo es que si la ley se acoge a esta posibilidad, habrá un único sujeto y una única obligación, exigiéndose directamente al ente el cumplimiento de las diversas prestaciones que la integren.». MARTÍN QUERALT, J; LOZANO SERRANO, C; TEJERIZO LÓPEZ, J. y CASADO OLLERO, G. (2007): Curso de Derecho Financiero y Tributario, Tecnos, Madrid, pág. 137; Para la doctrina que ha estudiado el sometimiento de los entes mencionados a las normas tributarias, lo relevante es la susceptibilidad de imposición, que se produce cuando el ente revela una cierta autonomía patrimonial y goza, también, de una cierta organización, pese a que carezca de personalidad jurídica... fondos de inversión, de capital-riesgo, de pensiones, etc. así como las UTE. MARTÍNEZ LAGO, M. A. y GARCÍA DE LA MORA, L.(2009), pág. 317.

${ }^{99}$ En tales casos, la LGT no ordena, sin embargo, que sean obligados tributarios en todo caso, sino meramente contiene la previsión genérica de que las leyes propias de cada tributo podrán considerarlo como tales. Y efectivamente, así ocurre en determinados tributos respecto a ciertos entes sin personalidad, mientras que en otros se prescinde de es posibilidad para gravar directamente a cada miembro integrante del ente sin personalidad. MARTINN QUERALT, J; LOZANO et alii (2007), pág. 137.

${ }^{100}$ Para FERREIRO, de los arts. 42.1.b), 45.3 y 48.2.c) LGT, debe entenderse, en primer lugar, que las personas que integran o componen el ente colectivo son, en todo caso, los sujetos pasivos, si bien la Hacienda Pública puede dirigirse indistintamente a ellos de forma unificada para exigir la totalidad de la deuda o de forma individual o aislada, es decir, como si tales personas no estuvieran insertas en el esquema colectivo para exigir la deuda 'en proporción a sus respectivas participaciones', sin que del art. 42.1.b) LGT quepa deducir la existencia de dos personas distintas. FERREIRO LAPATZA, J. J.(2006), 369-370.

(C) UNED. Revista de Derecho UNED, núm. 17, 2015 
personalidad se atribuiría exclusivamente para la realización de obligaciones y derechos tributarios ${ }^{101}$.

Estos entes carentes de personalidad ${ }^{102}$ pueden tener la condición de sujetos infractores, por un lado, como sujetos pasivos en los impuestos

${ }^{101}$ Ejemplos podemos encontrarlos en el art. 84.3 LIVA, y en el art. 7 LIS (v.gr. fondos). CALVO ORTEGA, R.(2010), págs.170-171; Fueron, sin duda, numerosos los autores (Giannini, Pugliese, Hensel, Bañón, etc) que defendieron la tesis de que la capacidad jurídica en Derecho Tributario es algo distinto de la capacidad jurídica tal y como está configurada en los Códigos Civiles. Para FERREIRO, esta posición es hija de un defectuoso planteamiento general de los problemas del Derecho Tributario. Nace de que estos autores examinan las normas de la Ley tributaria aislándolas, en mayor o menor medida, de la totalidad del ordenamiento jurídico...Afortunadamente, el punto de partida que nosotros consideramos necesario en el examen de todo problema jurídico-tributario, es decir, la consideración unitaria del ordenamiento jurídico, hizo que una valiosa parte de la doctrina demostrara, a nuestro modo de ver, de modo irrefutable, el absurdo en que se incurría al defender que determinados entes podrían tener capacidad jurídica en el ordenamiento tributario, sin poseerla en el ordenamiento general, o más simplemente, que la capacidad jurídico-tributaria era algo distinto de la capacidad tal y como ésta aparecía configurada en el Código Civil. La tesis señalada encontró un defensor de gran relieve en Berliri. La tesis de Berliri, se ha abierto camino definitivamente en nuestra patria, y demuestra a través de sus defensores (Vicente Arche, Cortés, Sáinz de Bujanda, principalmente) la imposibilidad de un examen aislado de las normas jurídico tributarias sin tener en cuenta el fondo jurídico común a todo el ordenamiento... La polémica tomó en España, a raíz sobre todo de los trabajos de Cortés Domínguez y Sáinz de Bujanda, un nuevo sentido tomando siempre como punto de partida la norma contenida en el art. 33 LGT 1963 y vertida ahora en el art. 35.4 LGT de 2003... Parece que dicha norma es contraria a la doctrina tradicional repetidamente aludida. Que no todo sujeto de derecho ha de ser, según ella, una persona física o jurídica capaz de derecho y obligaciones Que el ordenamiento puede, p.ej. crear un sujeto como simple centro de imputación de efectos jurídicos o para configurar subjetivamente una situación, sin que esto quiera decir que tales sujetos sean personas capaces de derechos y obligaciones. Sin embargo, entendemos que el propio texto de la Ley permite una interpretación mucho más fácil, obvia y sencilla, por lo que no parece necesario forzar una interpretación pretendidamente alambicada que se base en la vieja tesis de la capacidad tributaria distinta o en la ruptura con la doctrina común y generalmente aceptada sobre capacidad en todo el ordenamiento. Por ello parece necesario ahora insistir en que la doctrina no sólo tradicional sino todavía hoy absolutamente mayoritaria, mantiene la tesis de que sólo son sujetos de derecho las personas físicas y jurídicas... Y esto es lo que ha ocurrido, en mi opinión, en la cuestión... Ni la Ley de 1963 ni la actual dijeron nunca que tales entes sin personalidad son sujetos pasivos. Con toda intención y claridad dijeron y dicen que en las leyes que así se considere conveniente tales entes pueden «ser considerados» como si de un sujeto pasivo se tratara. FERREIRO LAPATZA, J. J.(2006), págs. 367-370.

${ }^{102}$ Cuando un precepto fiscal tipifica un ente colectivo no personificado como sujeto del tributo, le atribuye una capacidad de contribuir a título propio, de la que carece según las normas de derecho patrimonial común al no poder ser propietario de las rentas o patrimonios que se le imputan legalmente... adquiere la condición de sujeto del tributo o de sujeto infractor tributario en virtud de una ficción legal, que define como existente una capacidad de contribuir que es jurídicamente- según el Derecho privadoinexistente. PÉREZ DE AYALA, J. L. y PÉREZ DE AYALA BECERRIL, M.(2004), pág. 134; Los autores españoles han acudido generalmente a la noción de sujeto de derecho utilizada por GIARDINA en la doctrina italiana para explicar aquel recono- 
indirectos, y, por otro lado, como obligados tributarios sujetos a determinadas obligaciones, bien sustantivas (practicar retenciones) bien procedimentales (de declarar) en los impuestos de imposición directa. Para poder calificar la conducta de estos «entes de hecho» como dolosa o negligente habrá que examinar el comportamiento de los «órganos de hecho» a través de los que actúan. A la hora de hacer frente al pago de la sanción, en principio, y según el artículo 42.1.b) de la LGT, los copartícipes o cotitulares de estas entidades «responderán solidariamente, y en proporción a sus respectivas participaciones de las obligaciones tributarias materiales ${ }^{103} \mathrm{de}$ dichas Entidades», si bien, la sanción, opinamos, se debería exigir a las personas que hubiesen tomado parte en la comisión de la infracción ${ }^{104}$. Asimismo, entendemos que las entidades carentes de responsabilidad nunca podrán ser consideradas responsables ni solidaria ni subsidiariamente por así deducirse claramente de una lectura conjunta de los apartados $4 .^{\circ}$ y $5 .^{\circ}$

cimiento...En nuestra opinión, el hecho de que en determinados supuestos, una norma tributaria refiera la subjetividad a un ente sin capacidad jurídica no lo convierte en titular de esas situaciones, ni determina el reconocimiento autónomo de una capacidad jurídico-tributaria sino que, simplemente, incide en el modo en que las personas integradas en dichos entes asumen sus posiciones jurídicas, pues sólo ellas pueden ser titulares de derechos y obligaciones. BAYONA DE PEROGORDO, J. J. y SOLER ROCH, M.T. (1999), págs. 249 y 250; Para CORTÉS no hay problema que la ley considere destinatarios de las normas tributarias a entes colectivos...la subjetividad tributaria de los mismos agota sus efectos en la configuración del hecho imponible. CORTÉS DOMÍNGUEZ, M.(1965): «Los sujetos de la obligación tributaria», Revista de Administración Pública $(R A P)$, núm. 48, pág. 33; más allá va SAINZ DE BUJANDA que dichos entes no sólo configuran subjetivamente el hecho imponible sino que asumen, en posición deudora, la titularidad de la obligación, sin perjuicio de que de ésta puedan derivar ciertos efectos jurídicos a cargo de las personas que componen el ente. SAINZ DE BUJANDA, F.(1967); para FALCÓN este problema revela la tensión entre dos principios, el de justicia tributaria -evitando la rigidez de la personalidad jurídica- y el de seguridad jurídica -que exige que las relaciones se atribuyan a personas capaces-, concluye que la titularidad de las relaciones jurídicas pueden ser asumidas por un conjunto de personas en un régimen peculiar de actuación y responsabilidad (sociedad irregular) o por una persona transitoriamente indeterminada (herencia yacente), pero sólo impropiamente puede hablarse, en estos casos de sujetos pasivos, ya que los verdaderos sujetos son siempre las personas. FALCÓN Y TELLA, R. (1995): «Los entes de hecho como sujetos pasivos de la obligación tributaria», $R E D F$, pág. 657 .

${ }^{103}$ La Exposición de Motivos de la LGT en su apartado III, «de modo didáctico, se definen y clasifican las obligaciones, materiales y formales, que pueden surgir de la relación jurídico-tributaria. Las obligaciones materiales se clasifican en: obligación tributaria principal, obligaciones tributarias de realizar pagos a cuenta, obligaciones entre particulares resultantes del tributo y obligaciones tributarias accesorias». Para ANEIROS PEREIRA la LGT contiene un precepto específica para este tipo de entidades, el art. 42.1.b), y en la medida en que se considera que la sanción es una deuda de derecho público de naturaleza no tributaria no podrá exigirse a las personas físicas que forman parte de las entidad del art. 35.4 LGT. ANEIROS PEREIRA, J.(2005), pág. 58; No obstante dicho apartado b) deja a salvo la posible concurrencia de lo señalado en el art. 42.1.a) LGT.

${ }^{104}$ PÉREZ ROYO, F. y AGUALLO AVILÉS, A.(1996), pág. 225.

(C) UNED. Revista de Derecho UNED, núm. 17, 2015 
del art. 40 LGT. Así, las sanciones que pudieran proceder por las infracciones cometidas por las sociedades y entidades a las que se refiere este artículo serán exigibles a los sucesores de las mismas, en los términos establecidos en los apartados anteriores y, en su caso, hasta el límite del valor determinado conforme a lo dispuesto en el apartado 1 de este artículo. De ello se deduce que las sanciones impuestas a entidades del art. 35.4 LGT únicamente se transmitirán los «sucesores» de dichas entidades y no a los meros adquirentes por transmisión no sucesoria ${ }^{105}$, y observamos que sucesión no debe de ser término análogo al de transmisión -éste último sería un término más amplio que aquél-. De igual modo, el precitado apartado quinto remite su exigencia a los sucesores de las mismas, a lo dispuesto en los apartados primero a cuarto del artículo 40 LGT, no resultando mención alguna sobre en qué términos deberá responder el sucesor, ya que dicho precepto sólo trata la sucesión en las obligaciones tributarias y no la sucesión en las sanciones tributarias. Tampoco cabe inferir una remisión, a los apartados primero a cuarto del art. 40 LGT, por parte del párrafo segundo del apartado tercero del artículo 182 LGT, sino que este último artículo se remite al art. 40.5 LGT, y éste a lo que se indique sobre sanciones tributarias en cada uno de los párrafos $1 .^{\circ}$ a $4 .^{\circ}$ del art. 40 LGT, esto es, ninguno de ellos indica mención alguna al régimen de las sanciones, por lo que no resulta sencillo inferir que se trata de equiparar la sucesión de la obligación tributaria a la de la sanción cuando es el propio precepto el que no lo que ha querido señalar, de modo que donde el legislador no lo indica no debemos exigirlo nosotros.

En el ámbito punitivo de las personas jurídicas, el art. 129 CP, al mencionar a «empresas, organizaciones, grupos o cualquier otra clase de entidades o agrupaciones de personas que, por carecer de personalidad jurídica, no estén comprendidas en el artículo 31 bis de este Código...» ${ }^{106}$, da la impresión ${ }^{107}$ que el legislador haya queri-

${ }^{105}$ Además el propio artículo 40.4 LGT adveramos que no contiene regulación del régimen sucesoria para entidades del art. 35.4 LGT, pues la norma expresa que «las obligaciones tributarias pendientes de las mismas se transmitirán a los destinatarios de los bienes y derechos de las fundaciones o a los partícipes o cotitulares de dichas entidades», y el término dichas entidades entendemos que se refiere a dichas fundaciones, y no a dichas entidades carentes de personalidad jurídica. En ese sentido se viene a pronunciar el art. 177.2 LGT, donde en modo alguno se regula la figura de los sucesores de las entidades sin personalidad jurídica, y los partícipes o cotitulares lo son de la persona jurídica o fundación y no de la entidad sin personalidad jurídica.

${ }^{106}$ Incluso tras la redacción dada por los apartados 1 y 2 por el art. único.69 de la Ley Orgánica 1/2015, de 30 de marzo.

${ }^{107}$ ECHARRI CASI, F. J.(2011): «Las personas jurídicas y su imputación en el proceso penal: una nueva perspectiva de las garantías constitucionales», Diario La Ley, núm. 7632, Sección Doctrina, 18 May. 2011. 
do incorporar un régimen penal específico para los entes sin personalidad no recogidos en el art. 31 bis, con la imposición no de penas, sino de consecuencias accesorias, siendo las condiciones de aplicación de las penas diferentes, pero con igual denominación e idéntico contenido (fraude de etiquetas), cuya accesoriedad se predica respecto de la pena que corresponda a la persona física responsable del delito, siendo precisa la distinción de aquellos sujetos susceptibles de imposición de penas sobre la base de lo dispuesto en el art. 31 bis, respecto de otros entes sobre los cuales únicamente cabría la imposición de consecuencias accesorias, al no estar incluidas entre los sujetos a los que alude el citado precepto, pero sí en el extensivo y genérico concepto de «organizaciones» que utiliza el art. 129 CP; máxime cuando las penas (art. 33.7) y las consecuencias (art. 129) son idénticas como decimos. El legislador, ha suprimido del art. 129 CP la relación de las concretas «consecuencias accesorias» imponibles, para efectuar una remisión a los apartados c) a g) del art. 33.7 $\mathrm{CP}$, sustituyendo las referencias a la disolución de la sociedad, asociación o fundación por la más genérica de «disolución de la persona jurídica», evitando así algunas de las disfunciones que la redacción anterior podía llegar a causar.

\section{LA CONCURRENCIA DE VARIOS SUJETOS INFRACTORES. CONSIDERACIONES}

En el apartado 3 del artículo 181 LGT se establece la regla de la solidaridad ${ }^{108}$

${ }^{108}$ Que no mancomunidad. El responsable tributario solidario lo es respecto de cualquiera de los sujetos infractores principales, entretanto que la responsabilidad subsidiaria en la sanción tributaria únicamente tendrá lugar tras la declaración de fallidos de los infractores principales y todos los responsables solidarios. La Sentencia del TS de 18 de octubre de 2010, analizando la normativa anterior (arts. 37 y 40.1 LGT 1963 y art. 14.2 RGR de 1990 ), señala con rotundidad que «tanto el tenor literal de la ley como de su desarrollo reglamentario se colige claramente que la obligación de notificación al sujeto responsable se proyecta sobre la declaración y la derivación de responsabilidad, y en modo alguno se vincula con la notificación de la declaración de fallido del deudor principal y, en su caso, de los responsables solidarios ", siguiendo en este punto a la STS de 25 de abril de 2008 15, argumento que, a su vez, recogió también la STS de 29 de marzo de 2012 (RJ 2012, 4949) 16. En la misma línea, el TSJ de Asturias, en Sentencia de 26 de octubre de 2009. No obstante lo anterior, lo cierto es que tanto la constatación de la situación de insolvencia del deudor principal y, si los hubiera, de sus responsables solidarios, así como su plasmación en la declaración de fallido, son presupuestos necesarios para que pueda iniciarse un procedimiento de declaración de responsabilidad subsidiaria. Respecto de los responsables subsidiarios, el plazo de prescripción comenzará a «computarse desde la notificación de la última actuación recaudatoria practicada al deudor principal o a cualquiera de los responsables solidarios», término que ha planteado algunas dificultades de interpretación que han sido abordadas tanto por la doctrina como por la jurisprudencia, en muchas oca- 
siones con resultados dispares. A nuestro juicio, la adecuada interpretación de esta cuestión debe realizarse partiendo de los presupuestos que la normativa tributaria configura como determinantes de la responsabilidad subsidiaria. Pues bien, entre ellos, como hemos visto, la declaración de fallidos del deudor principal y sus responsables solidarios, independientemente de la vía que se considere válida para llegar a ella, constituye un aspecto esencial que, obviamente unido a la constatación de alguno de los presupuestos de hecho configurados por el legislador como constitutivos de los casos de responsabilidad subsidiaria, determinará la posibilidad de que un sujeto entre a formar parte del círculo de obligados tributarios a título de responsable subsidiario. No parece que pueda tener cabida la interpretación que trató de hacerse valer en algunos casos sosteniendo que la prescripción comienza a contar para el responsable desde el momento en el que termina el período voluntario de pago para el deudor principal. Tal y como aclaró la Audiencia Nacional en Sentencia de 8 de octubre de 2012. Lo que no es de recibo es pensar que el inicio del cómputo de la prescripción coincide en ambos casos, toda vez que los presupuestos de la responsabilidad son diferentes a los que concurren para determinar la obligación del deudor principal, aun cuando el primero de esos sujetos termine asumiendo la obligación del segundo. La misma teoría se acoge por el TS, en Sentencia de 21 de marzo de 2013. Lo que no nos parece de recibo, como parece afirmar el TS, es que la declaración de falencia abra el plazo de prescripción durante el cual el responsable deba satisfacer su deuda tributaria, entre otras cosas porque en tanto no exista acto declarativo de responsabilidad (posterior a la declaración de fallido que opera como presupuesto de la misma) no se abrirá el período voluntario de pago para el responsable subsidiario que, por otra parte, tampoco podrá hacer frente a su deuda como responsable antes de ser declarado como tal. Esto es, bajo nuestro punto de vista, la teoría de la actio nata implicará que la declaración de fallido opere como día de inicio del cómputo de la prescripción... Así pues, defendemos a este respecto la existencia de dos períodos de prescripción. El primero de ellos, para girar acto de derivación de responsabilidad, a contar desde que se hubiera dictado la declaración de fallido del deudor principal y sus responsables solidarios. El segundo, para exigir el pago de la deuda al responsable, que en nuestra opinión sólo puede comenzar con el acto de derivación de responsabilidad. Sostener lo contrario podría llevarnos a encontrar situaciones difíciles de justificar, tales como el hecho de que, declarado fallido el deudor principal se exija el pago a un sujeto que todavía no haya sido declarado responsable por la Administración y que, en última instancia, podría incluso evitar dicho acto administrativo de derivación de responsabilidad en atención a las alegaciones que en defensa de su derecho pudiera esgrimir en el trámite de audiencia con el que cuenta dicho procedimiento... la declaración de fallido lo que abre es el período de prescripción para dictar el acto de derivación de responsabilidad, y no para hacer efectivo el pago de una deuda cuyo pago, en puridad, la administración no puede exigir hasta que haya acto de derivación de responsabilidad.... sostener la inexistencia de un plazo para que la Administración pueda llegar a la declaración de fallido «es tanto como admitir» que la relación jurídica tributaria entre Administración y responsable subsidiario, con la consiguiente sujeción de éste como deudor, nacida con el presupuesto de la responsabilidad, tiene una duración indefinida y que puede prolongarse sin absolutamente ninguna actuación del acreedor en su seno tantos años como éste haga durar los procedimientos recaudatorios contra el obligado principal y los responsables solidarios. A nuestro juicio, si bien es cierto que la finalidad que inspira tal conclusión es plausible, atendiendo a la normativa vigente no es fácil de mantener. ÁLVAREZ BARBEITO, P (2013): "Aspectos controvertidos de la aplicación del beneficio de excusión del responsable subsidiario», Revista Quincena Fiscal núm. 18/2013. En definitiva, tanto el régimen sustantivo como el régimen procedimental de la responsabilidad -si es que cabe la 
-de sujetos infractores formalmente así declarados ${ }^{109}$ - en el pago ${ }^{110}$ de la sanción en los supuestos en que concurran ${ }^{111}$ varios sujetos infractores en la realización

separación entre ambos- abonan la conclusión de que la obligación del responsable es diferente de la del sujeto pasivo, guardando con ella la relación de dependencia y de subsidiariedad propia de las obligaciones de garantía como accesorias de la garantizada, pero sin que puedan confundirse entre ellas ni permitan entender que se está en presencia de una única obligación con varios obligados. El responsable y el sujeto pasivo son titulares de obligaciones distintas, cada uno por su propio título y con un objeto o prestación obligacional también diferente. LOZANO SERRANO, C.(2012): "La prescripción de la responsabilidad tributaria», Quincena Fiscal, n. ${ }^{\circ}$ 17, 2012.

${ }^{109}$ Aparentemente, contra los responsables tributarios, parece poderse ejercitar una acción tan solo, la recaudatoria, para exigir el pago de la deuda o de la sanción impuesta al deudor, sujeto pasivo. Así lo considera nuestra doctrina jurisprudencial.

Pero ello no creemos que sea así. A nuestro juicio, por el contrario, cabe identificar tres acciones distintas, por más que estén interrelacionadas y su finalidad sea común. Se trata de la acción de responsabilidad o de declaración de responsabilidad, de la acción de derivación de la acción de cobro contra el deudor sujeto pasivo y de la acción punitiva o sancionadora cuando el presupuesto de la responsabilidad es la participación del responsable en la comisión de las infracciones tributarias imputadas al deudor, sujeto pasivo, en uno u otro grado, o la comisión de infracciones propias. Delgado González, A. F; Ragel Bonilla, A. J.: (2013): «La prescripción de las acciones de responsabilidad, de derivación de la obligación de pago y de la punitiva o sancionadora que se pueden ejercer contra los responsables tributarios», Revista Quincena Fiscal núm.. 14/2013 parte Opinión Profesional, BIB 2013\1570.

${ }^{110}$ Para PALAO no debería de haberse otorgado la calificación de deudor al sujeto infractor, puesto que las sanciones no forman parte de la deuda tributaria conforme al art. 58.3 LGT. El proceder descrito es criticable por atentar con el principio de personalidad de las penas. La LGT termina considerando la sanción como si fuera un crédito ordinario de la Hacienda Pública, al que se puede hacer frente por parte de terceros si no paga el sujeto infractor. El infractor es quien tiene que pagar la sanción, dado el carácter punitivo de la misma. No se puede calificar a la sanción como un crédito, aunque aparentemente lo parezca y se utilicen sus reglas para su recaudación, puesto que su razón de ser es muy distinta a la del crédito tributario. PALAO TABOADA, C.(2004): Comentario sistemático a la nueva Ley General Tributaria, CEF, Madrid, pág. 539; Citando a NIETO GARCÍA, el hecho es único (un incumplimiento) y únicas también la acción y correlativamente la infracción y la sanción; lo que sucede es que de esas infracción y sanción únicas responden solidariamente todos los partícipes, de tal manera que, satisfecha la multa por uno de ellos quedan todos lo partícipes liberados; y, por lo mismo, la Administración puede exigir el pago total a cualquiera de ellos.... El problema está, no obstante, en determinar la parte que a cada uno corresponde, puesto que la solidaridad no se deriva de la obligación sino que viene impuesta por la ley y, la LRJPAC no sólo impone la solidaridad en la sanción sino también en la comisión de la infracción más sin señalar cuota. MARTÍNEZ LAGO, M. A.(2008): La extensión de la responsabilidad a las sanciones tributarias, Tirant lo Blanch, Valencia, págs. 156 a 159.

${ }^{111}$ El primer supuesto de responsabilidad solidaria recogido en el artículo 42 de la LGT es el de aquéllos que sean causantes o colaboren activamente en la comisión de una infracción tributaria, responsabilidad que, como se ha comentado, alcanza también a las sanciones. Se trata, como ha puesto de manifiesto CHECA GONZÁLEZ, reiterando lo señalado por el Tribunal Económico-Administrativo Central en su Resolución de 15 de enero de 1999, de una responsabilidad que, a diferencia de los restantes supuestos que descansan en conductas pasivas, requiere una conducta activa tendente a la comisión de la infracción. CHECA GONZÁLEZ, C.(2003): «Notas sobre la nueva regulación de los 
de una ${ }^{112}$ infracción tributaria, sin que se establezca una prelación o prioridad sobre los supuestos de lisa y llana responsabilidad solidaria establecidos en el art. 42.1.a) y c) y art.. 42.2 LGT ${ }^{113}$. El precepto resulta aplicable a

responsables tributarios en el Anteproyecto de la Ley General Tributaria», Jurisprudencia Tributaria Aranzadi 5/2003.

112 BAENA AGUILAR, A.(1993): «Reflexiones sobre jurisprudencia reciente en materia de infracciones y sanciones tributarias (I y II)», $Q F$, núm. 15, argumentaba: «Para la correcta compresión del tema debe partirse de las siguientes premisas:1)En nuestro Ordenamiento, pueden someterse a infracciones e imponerse las correspondientes sanciones por el incumplimiento de obligaciones o deberes tributarios no propios, sino ajenos. Si ... la LGT declara sujeto infractor al representante legal del incapaz, nada impide que lo puedan ser otras personas en una relación cualificada con una deuda tributaria ajena (verbigracia, los representantes voluntarios o negociases, en determinadas circunstancias; en este sentido, PEREZ ROYO, F.(1986), pág. 182; Sólo puede someterse una infracción tributaria (y, por imponerse una única sanción) por el incumplimiento de un mismo deber u obligación. El tratamiento que el Código Penal establece sobre grados de autoría y participación en el delito no existe en Derecho Tributario sancionador. El Código Penal prevé penas a cumplir por cada uno de los participantes, penas que son independientes entre sí, aunque se establezcan respecto de un mismo delito; en cambio, la sanción prevista para una infracción tributaria es siempre única. Debe aceptarse sin ambages que, en este particular, el Derecho Tributario sancionador es más rudimentario que el Derecho Penal. 3) Que la infracción y, en consecuencia, la sanción sean única; no implica: a)que la infracción haya sido cometida por una única persona; es decir, que sólo exista una persona infractora. En estos casos, cabe exigir el pago de la sanción en régimen de solidaridad. ...: en lugar de establecer la responsabilidad solidaria del colaborador, imponer la solidaridad entre infractores (personas que sean causantes o colaboren en una infracción tributaria), toda vez que se admite la comisión de una infracción por incumplimiento de un deber tributario ajeno. b)que la sanción pecuniaria derivada de dicha infracción deba ser cumplida en todo caso por la persona o personas infractoras. Como afirma la profesora OCHOA TREPAT, M. L.(1991): "Análisis del art. 40 de la LGT», en la obra colectiva Comentarios a la Ley General Tributaria y líneas para su reforma, Vol. I, Homenaje al profesor Sainz de Bujanda, IEF, Madrid, pág. 679, será cumplida por el autor y, en su defecto, por el responsable (si éste es subsidiario), o indistintamente por cualquiera de los dos cuando la responsabilidad es solidaria».

${ }^{113}$ El Tribunal Económico-Administrativo Central (en adelante el TEAC) 1, cuando ha analizado algún supuesto de los descritos en el artículo 42.2 de la LGT, considera que «la responsabilidad solidaria que en el mismo se establece, no es una responsabilidad de carácter tributario, sino más bien una responsabilidad por actos ilícitos que encuentra su fundamento en lo establecido en el artículo 1.902 del Código Civil».... Con todo ello, no creo que el instituto de la responsabilidad se pueda caracterizar por tener un matiz represivo o sancionador, incluso cuando el presupuesto de hecho sean actos ilícitos.... Sin embargo, a mi juicio, aunque puede considerarse como «una medida disuasoria de actuaciones que pueden dar lugar al incumplimiento», no se le puede atribuir carácter sancionador...El instituto de la responsabilidad, sea cual sea el presupuesto de hecho de la responsabilidad, se configura como una garantía tributaria en sentido técnico, es decir, un derecho subjetivo que se yuxtapone al derecho de crédito que se pretende asegurar, añadiendo a éste último algo que por sí mismo no tiene. Ruiz Hidalgo, C (2013). "La Ley 7/2012 de lucha y prevención contra el fraude fiscal en relación con los supuestos de responsabilidad del artículo 42.2 de la LGT», Revista Quincena Fiscal núm. 1/2013, BIB 2013\94. Desde algún sector de la doctrina se ha entendido que, en estos casos, la responsabilidad supone el castigo de un acto ilícito del responsable cuya sanción consiste en atender el pago exigido por la Administración, o lo 
los casos en que son varios los titulares del presupuesto de la obligación tributaria incumplida, y en este sentido, quizás, resulta más clara la dicción del apartado 3 del artículo 130 de la LRJPAC ${ }^{114}$.

A la vez que establece un supuesto de concurrencia de varios sujetos infractores en la realización de una infracción, contempla que queden, de suyo, solidariamente obligados ${ }^{115}$ frente a la Administración al pago ${ }^{116}$ de la sanción. En este caso, todos ${ }^{117}$ los sujetos infrac-

que es lo mismo, la responsabilidad tributaria por actos ilícitos constituye una sanción de garantía, como ha subrayado. FERREIRO LAPATZA, J. J. (1991): «Los sujetos pasivos de la obligación tributaria», Civitas-REDF, n. ${ }^{\circ}$ 72, pág. 484; por el mismo autor, Curso de Derecho Financiero Español, vol. II, 22. ${ }^{\mathrm{a}}$ ed., 2000, Madrid, págs. 67-68; ARIAS ABELLÁN, M. D. (1985): «Modificaciones a la Ley General Tributaria en la regulación jurídica del responsable», Civitas, REDF, n. ${ }^{\circ}$ 47-48, págs. 420-421.

${ }^{114} \mathrm{El}$ mismo señala que «cuando el cumplimiento de las obligaciones previstas en una disposición legal corresponda a varias personas conjuntamente, responderán de forma solidaria de las infracciones que, en su caso, se cometan y de las sanciones que se impongan»; En contra de que la responsabilidad por la sanción sea solidaria, FUSTER ASENCIO, C.(2001), pág. 112, quien opina que la sanción es personal e individual, la responsabilidad sólo cabe sobre la obligación tributaria.

${ }^{115}$ MUÑOZ BAÑOS cita a MORILLO MÉNDEZ quien dice que en el caso de los socios de sociedades disueltas y liquidadas «la perplejidad frente a la exposición crece de tono", puesto que, y esto es evidente, decir que se responde solidariamente hasta el límite del valor de la cuota de liquidación es negar que se responde solidariamente, porque no es fácil aplicar conjuntamente estos requisitos. MUÑOZ BAÑOS, C.(1999),.pág. 372; En efecto, una responsabilidad solidaria permite al acreedor, en este caso la Administración tributaria, dirigirse indistintamente contra cualquiera de los deudores, los socios o partícipes, para exigirles el pago de la totalidad de la deuda, sin perjuicio de la acción de repetición que, en su caso, corresponda a los deudores. Por ello, una solidaridad parcial porque entre en juego el mecanismo de la cuota de liquidación individual puede dar lugar a que se reitere el procedimiento de cobro a sucesivos socios, y lleva a la conclusión de que se tenga que declarar fallido el crédito tributario si excede de la suma de los bienes adjudicados. Esta circunstancia es la que induce a MARTÍNEZ LAFUENTE, también crítico con el precepto, a decir que sólo puede aplicarse este artículo cuando la deuda tributaria (sanción) se refiere a cada una de las cuotas de liquidación. MUÑOZ BAÑOS, C.(1999), págs. 372 y 373.

${ }^{116}$ La determinación de un conducta infractora y la sanción correspondiente se realiza en el procedimiento sancionador, por lo que atribuir competencias para derivar la sanción sería tanto como dotarlos de competencia sancionadora cuando la infracción no se ha cometido en el procedimiento de recaudación. Al derivar la sanción, la Administración está ejerciendo la potestad punitiva, al ser responsable de una sanción equivale a ser sancionado. ANEIROS PEREIRA, J.(2005), pág. 192.

${ }_{117}$ Quienes no distinguen entre la solidaridad por la comisión de la infracción tributaria y la responsabilidad tributaria solidaria están confundiendo dos formas de estar obligado solidariamente, la solidaridad de infractores y la solidaridad que se puede presentar entre quien es infractor principal y quien es titular de una obligación de pago de una sanción ajena. Así, la subsunción de la responsabilidad [impropia] tributaria solidaria bajo el concepto de solidaridad [propia o paritaria] tributaria (entre infractores principales) lleva a este sector doctrinal a consecuencias inaceptables, tales como: admitir que la Administración puede dirigirse discrecionalmente frente al infractor principal o al responsable tributario. GONZÁLEZ ORTIZ, D. (20030): La figura del responsable tributario en

(C) UNED. Revista de Derecho UNED, núm. 17, 2015 
tores son autores materiales de la infracción tributaria' ${ }^{118}$. A este respecto ESEVERRI manifiesta, al comentar el art. 42.1. letra a) LGT, que cuando la LGT califica como responsables solidarios ${ }^{119}$ de las deudas tributarias a las personas físicas o jurídicas -no los entes del art. 35.4 LGT- que sean causantes o colaboren activamente en la realización de una infracción tributaria -que incluiría, si participasen en la infracción, a los administradores de hecho o de derecho de personas jurídicas recogidos en el art. 43.1 a) ${ }^{120}$ LGT-, técnicamente ha-

el Derecho español, Tesis doctoral dirigida por D. Fernando Cervera Torrejón, Universitat de Valencia, Servei de publicacions, págs. 65-66.

118 MARTÍNEZ LAGO, M. A.(2008a): «Participación en infracciones y extensión de la responsabilidad a las sanciones tributarias», $Q F$, núm. 15.

${ }^{119}$ Art. 67.2 LGT: El plazo de prescripción para exigir la obligación de pago a los responsables solidarios comenzará a contarse desde el día siguiente a la finalización del plazo de pago en periodo voluntario del deudor principal. No obstante, en el caso de que los hechos que constituyan el presupuesto de la responsabilidad se produzcan con posterioridad al plazo fijado en el párrafo anterior, dicho plazo de prescripción se iniciará a partir del momento en que tales hechos hubieran tenido lugar. Tratándose de responsables subsidiarios, el plazo de prescripción comenzará a computarse desde la notificación de la última actuación recaudatoria practicada al deudor principal o a cualquiera de los responsables solidarios.

Art. 68.2 LGT: El plazo de prescripción del derecho a que se refiere el párrafo b) del artículo 66 de esta ley se interrumpe:

a) Por cualquier acción de la Administración tributaria, realizada con conocimiento formal del obligado tributario, dirigida de forma efectiva a la recaudación de la deuda tributaria. b) Por la interposición de reclamaciones o recursos de cualquier clase, por las actuaciones realizadas con conocimiento formal del obligado en el curso de dichas reclamaciones o recursos, por la declaración del concurso del deudor o por el ejercicio de acciones civiles o penales dirigidas al cobro de la deuda tributaria, así como por la recepción de la comunicación de un órgano jurisdiccional en la que se ordene la paralización del procedimiento administrativo en curso. c) Por cualquier actuación fehaciente del obligado tributario conducente al pago o extinción de la deuda tributaria. [Estas causas de interrupción entendemos que no resultarían de aplicación a la derivación de sanciones tributarias, de una interpretación conjunta de los arts. 182, 175, 176 y 190 LGT]

Art. 68.8 LGT: Interrumpido el plazo de prescripción para un obligado tributario, dicho efecto se extiende a todos los demás obligados, incluidos los responsables. No obstante, si la obligación es mancomunada y solo se reclama a uno de los obligados tributarios la parte que le corresponde, el plazo no se interrumpe para los demás. Si existieran varias deudas liquidadas a cargo de un mismo obligado al pago, la interrupción de la prescripción solo afectará a la deuda a la que se refiera. La suspensión del plazo de prescripción contenido en la letra b) del artículo 66 de esta Ley, por litigio, concurso u otras causas legales, respecto del deudor principal o de alguno de los responsables, causa el mismo efecto en relación con el resto de los sujetos solidariamente obligados al pago, ya sean otros responsables o el propio deudor principal, sin perjuicio de que puedan continuar frente a ellos las acciones de cobro que procedan.

${ }^{120}$ Interesante resulta, pese a que estima el recurso de casación, la STS de 9.04.2015 (unificación de doctrina), cuyo FJ 1 expresa «[m]ás adelante, la STS de 29-1-2009 (pronunciada en unificación de doctrina) matiza que «(e)s la imputación de esa conducta que el precepto del art. 40.1 describe la que genera la responsabilidad, no la existencia de infracción imputable a la persona jurídica y provocadora de una sanción. Por eso, el art. 40.1 posibilita una responsabilidad del administrador, sin que la entidad administrada 
haya sido sancionada y, en sentido inverso, infracción de la entidad sancionada, sin que exista responsabilidad en el administrador». El mismo criterio es el que informa la STS de 14-5-2009, cuando dice que "(a)l no existir identidad de conductas en las previsiones de ambos preceptos (el 37.3 y el 40.1 LGT), los mismos son compatibles. La responsabilidad que el art. 40.1 consagra no se genera por la conducta de la entidad, sino por la específica que el precepto describe, directamente imputable al administrador, y que es distinta de la que generó la sanción». En fin, a modo recapitulación, cabe reproducir aquí lo dicho en la STS de 25-4-2008, cuando declara que la aplicación de la norma del art. 40.1, primer párrafo, LGT «...exige la concurrencia de tres requisitos: a) comisión de una infracción tributaria por la sociedad administrada; b) condición de administrador al tiempo de cometerse la infracción; c) una conducta del administrador que se relacione con el propio presupuesto de la infracción en los términos señalados en el art. 40.1 LGT, reveladora de no haber puesto la diligencia necesaria en el cumplimiento de la obligación tributaria, extendiéndose la responsabilidad a la totalidad de la deuda tributaria en el caso de infracción grave».

QUINTO.- Los antecedentes legales y jurisprudenciales expuestos permiten extraer algunas conclusiones. Una de ellas es que la posibilidad de exigir a los administradores la responsabilidad ex art. 40.1, primer párrafo, LGT no se satisface mediante el automatismo de identificar la condición de administrador (acaso porque, como se ha dicho en alguna ocasión, los administradores tienen la obligación de adoptar las medidas necesarias para asegurar una ordenada gestión societaria que incluye la de los aspectos tributarios). Antes bien, es preciso algo más; es preciso que los administradores incurran en las conductas específicas que describe el precepto, lo cual impone a la Administración Tributaria una explicación de por qué el administrador a quien señala como responsable incurrió en alguna de aquéllas. Dicho en otros términos, la Administración Tributaria debe, en tales casos de imputación de responsabilidad, una motivación concreta sobre la conducta del administrador y que no se limite al mero señalamiento de la condición de administrador del supuesto responsable. La segunda de las conclusiones es que la derivación de responsabilidad ex art. 40.1, primer párrafo, LGT tiene función represiva, retributiva o de castigo, que es - por utilizar palabras del Tribunal Constitucional en sus SSTC 276/2000 y 132/2001 - lo que distingue a la sanción administrativa de otras resoluciones administrativas que restringen derechos individuales con otros fines. Sin perjuicio de la distinción entre la conducta infractora imputable la persona jurídica, por un lado, y la del administrador, por el otro -distinción que hace nuestro Tribunal Supremo-, interesa resaltar que aquella derivación de responsabilidad traslada la punición -el castigo- desde la persona jurídica hasta sus administradores. Así pues, a los administradores se les castiga con este particular mecanismo legal, no siendo sólo que respondan subsidiariamente de determinadas deudas pecuniarias como las multas. Por ello afirmamos que el precepto describe supuestos específicos de participación accesoria en la infracción tributaria que cometió la persona jurídica, lo que es consecuente con que el legislador de la Ley 10/1985 configure los supuestos específicos de responsabilidad del art. 40.1, primer párrafo, LGT a la luz de los principios de personalidad de la pena y de culpabilidad, pues si el legislador quiere que se castigue al responsable subsidiario es -primero- porque participó de alguna manera relevante, por acción u omisión, en la conducta infractora de la persona jurídica que administraba y -segundo- porque tal participación suya era reprochable en la medida que fue voluntaria o negligente. Con esto descarta una suerte de responsabilidad objetiva, una responsabilidad por deudas, que resultaría - por ejemplo- de que la responsabilidad subsidiaria atendiera en exclusiva a la condición de administrador de la persona jurídica.

.......

Motivación que se estima plenamente trasladable al presente caso, toda vez que la actual redacción del artículo 43.1.a) de la Ley 58/2003 reitera los requisitos que eran exigidos en este ámbito por el artículo 40. Uno, párrafo primero, de la Ley 230/1963, de 28

(C) UNED. Revista de Derecho UNED, núm. 17, 2015 
blando, quien colabora en la comisión de una infracción resultaría ser también infractor, bien como autor conjunto de la misma, bien como inductor o cooperador necesario, bien como cómplice. Sin embargo, estima el autor, la LGT no lo califica como tal, y lo convierte en un obligado tributario a título de responsable solidario junto a quien se sitúa para hacer frente, no solo del cumplimiento de la deuda tributaria impagada en período voluntario, sino además del pago de la sanción derivada del ilícito tributario ${ }^{121}$. Esta misma circunstancia acontecería para con los partícipes o cotitulares de entidades sin personalidad jurídica cuando hubieren colaborado o sido causantes en la realización de un acto ilícito (art. 42.1.b LGT). No obstante, existen autores que han defendido que no habría posibilidad de repetir ${ }^{122}$ contra el deudor o autor principal cuando la responsabilidad al pago deriva de la colaboración en una infracción tributaria aunque, a nuestro juicio, no existen motivos para distinguir lo que la Ley no distingue $^{123}$. La cuestión sería radicalmente distinta si se hubiese se-

de diciembre, General Tributaria. Consecuentemente, y por todo lo expuesto, no queda motivada la culpabilidad del actor y, por tanto, no concurren los requisitos del artículo 43.1.a) LGT para derivar el acuerdo de responsabilidad. Por lo que el acuerdo de derivación de responsabilidad tributaria debe considerarse nulo por contrario a Derecho.

${ }^{121}$ Ahora bien, es posible plantear si la colaboración o coautoría en la realización de cualquier conducta infractora en el orden tributario es conducta suficiente para calificar al culpable y coautor del ilícito como responsable solidario en el pago de la deuda tributaria (además de la sanción), o, si más bien, sólo cabe situar en esa posición deudora de responsable solidario al coautor o cómplice en una infracción tributaria relacionada con el incumplimiento total o parcial de una deuda tributaria. ESEVERRI MARTÍNEZ, E.(2011), págs. 174-179.

${ }^{122}$ Aunque MERINO JARA admite la acción de reembolso no sólo frente al deudor o infractor principal, sino también frente al resto de responsables solidarios que no efectuaron el abono. Merino Jara, I (2006): Acerca de la responsabilidad tributaria, Anuario de la Facultad de Derecho, núm. 24, 2006, pág. 19.

${ }^{123}$ Por esa razón, si el sujeto pasivo o deudor principal realiza el pago de la deuda tributaria, en la medida en que está satisfaciendo una deuda propia, no tendrá derecho a exigir el reembolso de la deuda satisfecha al responsable tributario, puesto que éste solamente estaba obligado al pago de la deuda ajena; pero, si el pago lo realiza el responsable tributario, en la medida en que la deuda tributaria es una deuda ajena, podrá exigir al deudor principal el reembolso de lo pagado (principio de no reciprocidad).... El fundamento de la pretensión de reembolso que corresponde al responsable tributario contra el sujeto pasivo o deudor principal no se encuentra, como muchas veces se ha dicho, en la realización del principio de capacidad económica... Por el contrario, el fundamento de la pretensión de reembolso reside en el enriquecimiento injustificado que se produce en la esfera patrimonial del sujeto pasivo o deudor principal, con independencia de que este último sea el destinatario jurídico del tributo o, por el contrario, no el titular de la capacidad económica y tenga derecho a trasladar jurídicamente la carga tributaria a un tercero. El pago de la deuda tributaria ajena produce, en primer lugar, un enriquecimiento del deudor principal o sujeto pasivo, como resultado de la disminución de su pasivo patrimonial. En segundo lugar, el pago de la deuda tributaria ajena genera un empobrecimiento del responsable tributario a costa del enriquecimiento del sujeto pasivo o deudor principal... En ter- 
guido la recomendación del Informe de 2001 para la Reforma de la Ley General Tributaria, que proponía la creación de la figura del colaborador en una infracción tributaria, al que se le impondría una sanción propia. En tal caso, resultaría evidente la imposibilidad de exigir ningún tipo de reembolso en lo relativo a la sanción, por cuanto el colaborador estaría pagando por una infracción propia (cuya sanción le habría sido impuesta).

Planteamos una nueva cuestión, consistente en determinar si el coautor o partícipe debe ser sancionado de modo independiente ${ }^{124}$, o debe res-

cer lugar, existe un nexo causal directo entre el enriquecimiento del deudor principal y el empobrecimiento del responsable tributario, pues, el primero tiene su causa precisamente en el segundo. Por último, es posible afirmar que el enriquecimiento del deudor principal carece de una causa que lo justifique, lo que no significa que el correlativo empobrecimiento carezca a su vez de fundamento legal. GONZÁLEZ ORTIZ, D.: La figura del responsable tributario en el Derecho español, Tesis doctoral dirigida por D. Fernando Cervera Torrejón, Universitat de Valencia, Servei de publicacions, 2003, págs. 50-55. La justificación puede radicar en la posibilidad de que el responsable tributario ejercite la acción de regreso que atribuye el artículo 1.838 del C. C. al fiador, por tener igual estructura la relación entre infractor principal y responsable, o en base a la doctrina jurisprudencial de la prohibición de enriquecimiento sin causa, que puede ser considerada como un principio general del Derecho, aplicable más allá de los limites del ordenamiento jurídico privado.

${ }^{124}$ La Ley General Tributaria no declara al responsable, en estos casos, como sujeto infractor y trata de disociar la acción punitiva de la acción recaudatoria. Ello es lo que se deduce de lo dispuesto en los artículos 1812 y 1821 y 2 de la Ley General Tributaria. Entendemos que esta disociación no es admisible a la luz de lo dispuesto en el artículo 25 de nuestra Constitución de acuerdo con la interpretación del mismo realizada por nuestro Tribunal Constitucional. No es posible porque la derivación de la responsabilidad, en estos casos, tiene su fundamento en la participación del responsable en la comisión de las infracciones imputadas al sujeto pasivo o en la comisión de infracciones propias. Ello es lo que se deduce de lo establecido en los artículos $421 \mathrm{c}$ ), y $431 \mathrm{~g}$ ) y h). En los casos recogidos en el artículo 422 de la Ley General Tributaria, antes transcrito, bien pudiéramos hablar de la comisión de ilícitos propios aunque no estén tipificados como infracción. Es decir, en todos estos casos, se es responsable porque se es infractor. Y sólo en atención a ello se pueden imponer y exigir sanciones. El principio de personalidad de la pena, recogido en el artículo 25 de la Constitución, artículo tanto relativo al orden penal como al administrativo, impide la imposición de sanciones al que no es infractor. Si se exigen al responsable sólo deudas tributarias, puede distinguirse, conforme a los preceptos transcritos, el ejercicio de dos acciones distintas. En primer lugar el ejercicio de la acción de responsabilidad para declarar al tercero responsable. En segundo lugar el ejercicio de la acción de cobro contra el ya declarado responsable, ejercitada antes frente al deudor, sujeto pasivo. En el caso de que al responsable también se le exija el pago de las sanciones impuestas al deudor, sujeto pasivo, junto a estas dos acciones se ejercitará la acción punitiva o sancionadora. Por lo demás, la acción de responsabilidad se ha de ejercer a través de un procedimiento en el que cabe distinguir tres momentos básicos: el inicio, el trámite de audiencia y la declaración de responsabilidad. Delgado González, A. F; Ragel Bonilla, A. J.: (2013): «La prescripción...» op.cit. 
ponder de la misma sanción que los demás infractores. Esta última opción de solidaridad en el pago de la sanción ${ }^{125}$ por parte de los distintos sujetos infractores podía y puede llevar a la impunidad de alguno de ellos, puesto que, tanto si se paga la totalidad de la sanción por uno de ellos sin repetir contra los demás lo pagado, como si el responsable ejercita con éxito la acción regreso contra el resto de infractores, el importe de la multa va a recaer exclusivamente sobre uno de los autores, tesis que se acogió por el Tribunal Constitucional en su Sentencia 76/1990, de 26 de abril, que admite que no se traslade al ámbito sancionador tributario la interdicción constitucional de la responsabilidad penal solidaria ${ }^{126}$.

Ello supone confundir ${ }^{127}$ la responsabilidad punitiva con otro tipo de responsabilidad, ${ }^{128}$ vulnerando el principio de personali-

${ }^{125}$ MUÑOZ BAÑOS considera que en el caso de entidades disueltas y liquidadas, responden solidariamente los socios o partícipes de cualquier obligación tributaria pendiente excepto de las sanciones, por lo que éstas no son transmisibles y cuando una persona jurídica se disuelve y liquida, las sanciones que pudieran corresponderle por infracciones cometidas se extinguen, excepción hecha que los socios o partícipes hayan colaborado en la realización de las infracciones, entonces sí responden. MUÑOZ BAÑOS, C. (1999). pág. 374.

${ }_{126}$ PÉREZ ROYO, F.(1986), pág. 292; ZORNOZA PÉREZ, J. J.(1992).pág. 192.

127 Tal es la confusión que se empeora la posición del responsable solidario con ocasión de la reforma del art. 41.4 LGT por la Ley 7/2012, cuya Exposición de Motivos y fundamento consistía en permitir beneficiarse de la reducción legal por conformidad al responsable solidario. Así en los casos en que con independencia de que el previo deudor principal-infractor, hubiere prestado o no conformidad, la derivación de la responsabilidad seguirá curso propio pudiendo llegar a suponer una deuda mayor -que la del infractor principal- para el responsable que no otorga conformidad (a supuestos algo diferentes a los previstos para el infractor principal), v.gr. porque recurre. Introducir un criterio de graduación de sanciones en una institución que, se dice, no tiene dicha naturaleza supone poco menos que una contradicción. Exigir la conformidad con la sanción supone un atentado contra el principio de proporcionalidad, ya que se exige mucho más al responsable (conformidad a la procedencia de la derivación + a la totalidad de la deuda derivada) que al sujeto infractor (conformidad a la regularización). Por tanto, entendemos que la única interpretación posible del art. 41.4 LGT es que se permita al responsable de beneficiarse del otorgamiento de la conformidad que previamente no otorgó el infractor, pero no perjudicar a aquél cuando ya se ha otorgado conformidad por el infractor principal.

${ }^{128}$ Para MARTÍNEZ LAGO por mucho que la Administración quiera extender su desconfiada mirada, lo cierto es que comprar empresas no constituye algo ilícito ni disonante con el modelo económico que impera, por lo que lo más probable es que esos procesos no respondan a ningún comportamiento culpable de los agentes que intervinieron en los mismos. Sólo esa infracción del principio de culpabilidad bastaría para sostener la inconstitucionalidad de este supuesto de responsabilidad, cuyo fundamento está al margen del reproche de la participación en la comisión de infracciones. También se pospone el principio de proporcionalidad entre la sanción atribuida al responsable y el hecho que motiva esa traslación, al realizar la misma conducta quien deja de solicitar el certificado sin que haya sanciones a las que extender la responsabilidad que el sujeto al que sí se extienden por uno, por mil, por un millón...En definitiva, la imaginación administrativa, plasmada legalmente, presenta una realidad deformada en la 
dad de la pena' ${ }^{129}$. Abogamos, como hacen CALVO ORTEGA ${ }^{130}$ y ZORNOZA PÉREZ ${ }^{131}$, por sancionar de manera independiente a cada uno de los sujetos, proponiendo la modificación de la regula-

que la extensión de la responsabilidad a las sanciones representa el disfraz de la sanción que la Administración pretende imponer a los adquirentes que incumplan un hipotético deber de requerir información a la misma sobre las obligaciones contraídas por el anterior titular (SIMÓN ACOSTA 2004: 720). Ello representa, sin duda, una informal y deficiente tipificación de un supuesto infractor separado de los tipos enunciados por la LGT en sus artículos 191 y siguientes, lo que vulnera las exigencias de lex certa que impone el principio de tipicidad. La responsabilidad tributaria por entorpecer la ejecución recaudatoria.... quizás hubiese sido preferible la tipificación de los comportamientos enunciados más atrás como verdaderas infracciones autónomas. Lógicamente, esa solución habría propiciado un mejor esclarecimiento de las relaciones con la figura del delito de alzamiento de bienes a la luz del principio de no concurrencia y, también, de la necesidad de clarificación entre las conductas de causantes y colaboradores en infracciones. La transgresión, en efecto, del principio de non bis in idem, que algún autor ha sugerido (CALVO ORTEGA, R.(2004): La nueva Ley General Tributaria, Civitas, Madrid, págs. 176 ss.), nos parece difícilmente explicable con esta imperfecta tipificación de conductas ilícitas. Y, por otra parte, la diferenciación entre lo que representa causar y colaborar en una infracción implicaría recoger legalmente y desde la perspectiva sancionadora, diversos grados de participación en la ejecución de la misma... abandonando este largo camino de la desnaturalización de instituciones tributarias con la informal previsión de conductas ilícitas que se sancionan irregularmente a través de la extensión de la responsabilidad a la sanción de otro. MARTÍNEZ LAGO, M. A.(2008a).

${ }^{129}$ ANEIROS PEREIRA, J.(2005): Las sanciones tributarias, Marcial Pons, Madrid, pág. 42; Como ha expuesto RODRÍGUEZ MÁRQUEZ «la interpretación correcta del principio de personalidad de la pena en el ámbito administrativo exige desterrar la extensión de la responsabilidad de las sanciones», incluso cuando el responsable haya participado en la comisión de la infracción. Y ello, como expone el citado autor, por varias razones.- La primera es que si el obligado principal no ingresa la cuantía de la deuda tributaria, así como el importe de la sanción, la Administración se dirige contra el responsable y, si éste no logra ejercitar con éxito la acción de regreso contra el primero, tendrá que soportar la totalidad de la sanción.- En segundo lugar, puede suceder a la inversa, es decir, que el obligado principal ingrese la deuda, incluida la sanción, en período voluntario y, por lo tanto, el responsable que ha participado en la conducta ilícita, no sufra ninguna reacción represiva. En ambos casos, la extensión de la responsabilidad a las sanciones supone dejar el ejercicio de la potestad sancionadora en manos de los particulares y los tribunales ordinarios.- En tercer lugar, la extensión de la responsabilidad a las sanciones impide aplicar de manera individualizada la sanción y, correlativamente, los criterios de graduación de las mismas. RUIZ HIDALGO, C (2013). «La Ley....»p. cit. RODRÍGUEZ MÁRQUEZ fundamenta estas conclusiones en la sentencia del TS de 16 de mayo de 1995, que afirma que «la imputabilidad solidaria impide la efectividad de otro principio básico del orden sancionador, cual es el de proporcionalidad, al no ser susceptible la sanción impuesta solidariamente de graduación o moderación atendiendo a las circunstancias personales e individuales de cada uno de los infractores, lo que, en definitiva, corrobora la vulneración del principio fundamental, antes aludido, de responsabilidad personal»

${ }^{130}$ Calvo Ortega considera que el responsable tributario por actos ilícitos carece de acción de regreso frente al deudor principal, ya que de lo contrario su ilícito quedaría sin sanción.

${ }^{131}$ ZORNOZA PÉREZ, J. J.(1992), págs. 192 y 193; CALVO ORTEGA, R.(2010), pág. 453.

(C) UNED. Revista de Derecho UNED, núm. 17, 2015 
ción de la responsabilidad solidaria por la comisión de actos ilícitos basándose en los principios constitucionales de la responsabilidad personal ${ }^{132}$.

Una recta intelección del precepto 181.3 de la LGT debe llevarnos a que la responsabilidad sea solidaria ${ }^{133}$ en el pago de la sanción únicamente en aquellos casos en que dicho responsable estuviera obligado solidariamente a la realización del hecho imponible. Así, salvo en los supuestos de los artículos 195 a 197 LGT- en que los socios son responsables de la sanción de la Entidad, además de autores si dejasen de ingresar-, la solución para la coautoría será la solidaridad en el pago de la sanción cuando también exista solidaridad en la realización del presupuesto de hecho de la obligación o si ha colaborado de modo activo en la comisión de la infracción, lo que no excluye que ese responsable deba actuar de modo culposo o doloso, en otro caso no tendrá responsabilidad, pese al carácter predominantemente civil de esta responsabilidad ${ }^{134}$.

${ }^{132}$ Así las SsTS de 16 de febrero de 1990 y de 16 de mayo de 1995; también, exigiendo tipos específicos de infracción en base a su grado de participación. MARTíNEZ LAGO, M. A. y GARCÍA DE LA MORA, L.(2009), pág. 518.

${ }^{133}$ Abiertamente postulan la no inclusión de las sanciones en el régimen de responsabilidad tributaria, las SsTC 146/1994 y 36/2000 - al considerar afectado el principio de personalidad de la pena o de la sanción que deriva del art. $25 \mathrm{CE}$, fallaban que el responsable sólo responderá de las infracciones en la medida en que pueda imputársele y reprochársele jurídicamente la autoría o participación en una infracción-, y más claramente la STS de 30 de enero de 1999, y la SAN de 28 de septiembre de 2000, que sentencia que las sanciones no se extienden al responsable sea solidario, sea subsidiario; MARTÍN QUERALT, J; LOZANO SERRANO, C; TEJERIZO LÓPEZ, J. y CASADO OLLERO, G.(2005): Curso de Derecho Financiero y Tributario, Tecnos, Madrid, pág. 516; PÉREZ NIETO, R. y BAEZA DÍEZ-PORTALES, M.(2008): Principios del Derecho Administrativo Sancionador Vol. I, CGPJ-Fundación Wellington, Madrid, pág. 279; MARTÍNEZ MICÓ expone que la doctrina indicó que en los casos en los que el responsable tributario responde de las sanciones, lo hace en su condición de sujeto infractor y con independencia de que el deudor principal satisfaga o no el crédito tributario. La exclusión de las sanciones tiene sentido cuando el presupuesto de la responsabilidad es un acto lícito pero no debe producirse cuando el hecho que origina la responsabilidad es un acto ilícito del responsable; en los casos en que la responsabilidad esté constituida por la participación del responsable en la comisión de una infracción, deberá aquél responder de la sanción correspondiente a la infracción por él cometida. La sentencia del TS de 14 de mayo de 2009 (rec. Casación núm. 818/2003), ante el argumento de la naturaleza intransmisible de las sanciones, puntualiza que «lo derivado no es la sanción en su día impuesta al responsable principal. Lo derivado es la responsabilidad en que incurrió el propio responsable subsidiario al llevar a cabo los actos constitutivos de las infracciones tributarias. Hasta tal punto es esto así que el responsable subsidiario quedaría excluido de esta responsabilidad si acreditara que fue ajeno a las infracciones sancionadas». (Fundamento de Derecho Quinto). MARTÍNEZ MICÓ, J. G.(2009):«El alcance de la responsabilidad tributaria de los administradores de sociedades: su extensión a las sanciones», $Q F$, núm. 22.

${ }^{134}$ ANEIROS PEREIRA, J.(2005), pág. 42; PÉREZ ROYO, F.(1986) págs. 293; ZORNOZA PÉREZ, J. J.(1992), pág. 195. 
Existirán varios sujetos infractores porque existen varios sujetos que realizan la infracción ${ }^{135}$, algo que sirve para descartar imaginables situacio-

${ }^{135}$ En ese sentido debemos entender el artículo 42.1.c) de la LGT, en relación con el 175.2 y 182.1 de la LGT, cuando el cesionario será responsable de las sanciones exigidas -o que pudieran exigirse- al transmitente, siempre y cuando éstas deriven del ejercicio de la actividad que se transmite, sin que dicha responsabilidad pueda alcanzar ... a las sanciones consecuencia de actuaciones personales y ajenas a la explotación económica. En nuestra opinión, la regulación actual de la cuestión examinada en estas líneas responde a la lucha del legislador por evitar situaciones fraudulentas 34; ahora bien, en vez de recurrir a los mecanismos que ofrece el Derecho privado o el penal 35, en el ámbito tributario se ha optado por extender, sin justificación alguna, el alcance de la responsabilidad en la transmisión de empresa. El problema principal radica, como bien se supondrá, que en el supuesto analizado debe responderse de las sanciones imputables al anterior titular, tanto en el caso de conductas fraudulentas como cuando no lo son. Asimismo, no resulta coherente la extensión de la responsabilidad a las sanciones, en los casos de transmisión de una empresa por actos inter vivos, con el hecho de que si la misma opera mortis causa aquéllas queden excluidas (art. 39.1 LGT), o que en el supuesto de extinción de personas jurídicas y entidades sin personalidad la responsabilidad de los socios y partícipes se limite, en todo caso, al valor de la cuota de liquidación (art. 40.5 LGT). A nuestro juicio, no resulta conforme con los principios de personalidad de la pena y culpabilidad hacer al cesionario responsable de las sanciones por infracciones en las que a priori no ha tenido ninguna participación, situándolo, además, por delante de los propios administradores de la empresa. En este sentido se han pronunciado ARRIBAS LEÓN, M.(2004): Sucesión de empresas y responsabilidad tributarias, Marcial Pons, Madrid, pág. 257; BARRACHINA JUAN, E.(1998): «Responsabilidad tributaria del adquirente de una empresa: supuesto irregular de sucesión», Gaceta Fiscal $(G F)$, núm. 169, pág. 70; La respuesta a la cuestión relativa a la posibilidad de extender legítimamente la responsabilidad tributaria sobre las sanciones varía sustancialmente cuando se niega la naturaleza sancionadora, en sentido estricto, de la responsabilidad tributaria sobre las sanciones impuestas al deudor principal. Un sector de la doctrina científica ha defendido la posibilidad de hacer responsables de las consecuencias jurídicas de la infracción a personas distintas del sujeto infractor, negando que dicha extensión de responsabilidad constituya realmente la aplicación de una sanción, siguiendo a NIETO GARCÍA, A. y GONZÁLEZ ORTIZ, D.(1999): «Responsabilidad tributaria y sanciones», Jurisprudencia Tributaria (JT), vol. II, BIB 1999\1155; MORÓN PÉREZ, M. ${ }^{a}$ C.: Régimen tributario de la transmisión de empresa, Aranzadi, Cizur Menor, pág. 284; Para ello se ha trasladado al ámbito penal y administrativo sancionador la conocida disociación entre la deuda y la responsabilidad, propia de la teoría general de las obligaciones, distinguiendo entre autoría de la infracción y responsabilidad sobre la sanción. Según esta postura, el infractor sería el autor de la infracción y la persona en quien deberá concurrir el requisito subjetivo de la culpabilidad. Por el contrario, el responsable será aquella persona, autor o no de la infracción, a quien la ley impone el deber de soportar las consecuencias de la infracción, es decir, la sanción y, en su caso, la reparación, sin necesidad de que su comportamiento sea culpable. NIETO GARCÍA, A.(1994), págs. 390 a 397; ORENA DOMÍNGUEZ, A.(2003): "La sucesión de empresa y el principio de personalidad de la pena en el proyecto de la nueva Ley General Tributaria», JT, tomo II, pág. 2316; RUIBAL PEREIRA, L.(2005): «La nueva regulación de la sucesión en la titularidad o ejercicio de explotaciones o actividades económicas como supuesto de responsabilidad tributaria», en la obra colectiva Estudios de Derecho financiero y tributario en homenaje al profesor Calvo Ortega, tomo I, Lex Nova, Valladolid, 2005, pág. 486; SIMÓN ACOSTA,

(C) UNED. Revista de Derecho UNED, núm. 17, 2015 
nes de responsabilidad declarada diversas de las previstas en el artículo 182 LGT $^{136}$. Nos encontramos ante un supuesto de responsabilidad directa

E.(2004), págs. 719 y 720; VARONA ALABERN, J. E.(2000): «La responsabilidad tributaria de los síndicos», Impuestos, tomo II, pág. 336; Nos encontramos ante el único supuesto en el que la responsabilidad por las sanciones se basa en un presupuesto lícito (el del art. 42.1.c) LGT); por ello, entendemos que, de lege ferenda, debería eliminarse del texto de la LGT el inciso correspondiente a la extensión de la responsabilidad del adquirente a las sanciones contraídas por el titular originario de la explotación económica. Otra cosa sería, como bien ha apuntado la doctrina, que aquél hubiera participado en la comisión de la infracción de la cual se deriva la correspondiente sanción, pero en este caso no se trataría de la transmisión de la misma al cesionario, sino de la imputación de una conducta sancionable al declarado responsable...El certificado, en un sentido subjetivo, pues aquél sólo exonera de responsabilidad respecto de las deudas cuya liquidación compete a la Administración a la que se solicita la certificación (art. 125.3 RGR). Más en concreto, el citado certificado restringe el alcance de la responsabilidad en el sentido de que sólo deberá responderse por las deudas, sanciones y responsabilidades que en el mismo aparezcan reflejadas. CARRERAS MANERO, O.(2009): «El alcance de la responsabilidad tributaria del adquirente de explotaciones económicas», Aranzadi Doctrinal, núm. 5, [En este artículo se cita abundantemente doctrina actual sobre el extremo tratado];, la SAN de 26 de enero de 2009, al juzgarse un supuesto de la anterior LGT de 1963 Ley que no se expresaba la transmisión de las sanciones a los responsables -en lo que a nosotros concierne, el adquirente de la explotación o actividad económica-, concluye la AN que sólo puede llevarse la transmisión de la sanción si aquéllos han participado en la comisión de la infracción tributaria junto con el deudor principal. Con la actual LGT, que sí regula dicha transmisión, estimamos que cuando la transmisión de la empresa no se haya realizado de forma fraudulenta y el adquirente no haya participado en la comisión de la infracción no deberían exigírsele, en ningún caso, las sanciones impuestas al deudor principal, y ello aunque éstas deriven del ejercicio de la actividad transmitida. Vulnera el art. 42.1.c) LGT los principios constitucionales de personalidad de la pena, culpabilidad, y también el de seguridad jurídica, al hacer responsable al adquirente, incluso, del importe de unas sanciones que en el momento de la cesión empresarial ni siquiera han sido impuestas. CARRERAS MANERO, O. (2010): «La cuestionable constitucionalidad de la transmisión de las sanciones tributarias en los supuestos de cesión de explotaciones o actividades económicas», $Q F$, núm. 5; En resumen, la figura que examinamos no puede ser calificada como un caso de novación (asunción de deuda) aunque sea simplemente modificativa. Es un supuesto de responsabilidad tributaria...que tienen una finalidad estricta de garantía.... El sucesor es responsable de la deuda tributaria, incluidas las sanciones. La sucesión inter vivos (en el sentido que no es mortis causa) se produce en los casos de fusión de sociedades....estamos ante una sucesión universal con extinción del contribuyente y transmisión a la entidad adquirente ope legis de los derechos y obligaciones tributarias de la entidad que se extingue. Su ejemplo está en el artículo 84 del LIS. En este caso, se transmiten otros elementos además de la cuota, dado el carácter voluntario de la «asunción» y el derecho a conocer el montante de la deuda misma. La LGT ha declarado expresamente que se transmiten las sanciones debidas a infracciones, cometidas por las sociedades y entidades que se extinguen (art. 40.5 LGT). CALVO ORTEGA, R.(2010), págs. 191-192.

${ }^{136}$ Los responsables solidarios- partícipes no intervienen con el mismo título y cualidad, resultando por ello que la solidaridad entre el sujeto infractor (autor) y el responsable de la sanción sea una solución, si cabe, más incorrecta aún que la otra respecto del principio de personalidad de la sanción; claro, que para que éste se viese 
del sujeto infractor, en el que habrá que analizar uno a uno si se dan los requisitos de imputabilidad y culpabilidad necesarios para que su acción individual pueda ser constitutiva de infracción ${ }^{137}$. Téngase en cuenta ${ }^{138}$ que si la solidaridad entre una pluralidad de infractores (supuesto del art. 181.3 LGT) resulta poco respetuosa con el principio de personalidad de las sanciones, la solidaridad entre personas cuya aportación a la ejecución del ilícito tiene entidad distinta (supuesto del artículo 182.1 LGT) resulta, si cabe, todavía más incorrecta, mientras no exista una regulación expresa del prorrateo interno entre la pluralidad de sujetos infractores. Además, entendemos que responsable de la sanción nunca podrá serlo quien sea sujeto infractor, como, entendemos, acontece con quien es sujeto pasivo del tributo, que nunca podrá ser responsable de la deuda tributaria.

La LGT regula de manera asistemática ${ }^{139}$ la autoría [a título de infractor principal] y participación ${ }^{140}$ en la infracción [a título de responsable del pago de la sanción ${ }^{141}$ ], y a diferencia de lo que sucede en el Código Penal,

satisfecho, lo procedente sería aplicar sanciones propias a cada sujeto interviniente en el hecho ilícito, pudiendo también apreciarse criterios de graduación de las multas individualizados ( HERRERA MOLINA 1997: 13). Ello resultaría coherente, además, con las exigencias de proporcionalidad ( GONZÁLEZ ORTIZ 2006: 10) y respeto al principio de culpabilidad (Cambra Gras, J. M.; Pérez Miñana, R.(2005): «Capítulo II. Disposiciones generales sobre infracciones y sanciones tributarias», en la obra colectiva GARBERÍ LLOBREGAT, J.(Dir.); BUITRÓN RAMÍREZ, G. et alii, Procedimiento Sancionador. Infracciones y Sanciones Tributarias. (Comentarios, Jurisprudencia, Formularios, Ejemplos Prácticos y Legislación), Tomos I. y II, Tirant Lo Blanch, Valencia, pág. 435). MARTÍNEZ LAGO, M. A.(2008a).

${ }^{137}$ LAMOCA PÉREZ, C. (2005) pág. 156; DÍEZ OCHOA indica, en igual sentido, que «estamos en presencia de tantos sujetos infractores como obligados tributarios, pero referido todo ello a una misma conducta ilícita constitutiva de una única infracción, de tal manera que existe una sola sanción, la cual podrá exigirse íntegramente a cualquiera de los sujetos infractores por cuanto todos y cada uno de ellos son deudores principales de la misma (ex art. 181.2 LGT). DÍEZ OCHOA, J. M.(2006), pág. 68.

${ }^{138}$ MARTÍNEZ LAGO, M. A.(2008), págs. 174 y 175.

139 Podemos encontrar diversas regulaciones sobre la responsabilidad, solidaria o subsidiaria, en la que se aluden a supuestos de responsabilidad en el pago o en el ingreso de deudas tributarias, como por ejemplo el art. 9 RD Lg 5/2004, de 5 de marzo, o art. 57 Ley 27/2014, de 27 de noviembre, o art. 8 en relación al art. 38.1 Ley 29/1987, de 18 de diciembre, o arts. 9 y 35 RDLg 1/1993, de 24 de septiembre, o arts. 87 en relación al 170. Dos.2. ${ }^{\circ}$ y Anexo Sexto.3..$^{\circ}$ Ley $37 / 1992$, de 28 de diciembre, o apartados $4 .^{\circ}$ y $5 .^{\circ}$ del art. 8 de la Ley 38/1992, de 28 de diciembre, y art. 4 RD 1299/1986, o en el art. 9.3 de la Ley 13/1996, de 30 de diciembre. Excluyendo, en algunos casos expresamente, la responsabilidad tributaria en el pago de sanciones.

${ }^{140}$ Exigir al responsable tributario el pago de una sanción tributaria cuya existencia no guarda relación con la infracción tributaria en la que ha participado no resultaría lógico, por tanto debemos exigir relación entre los hechos en que se participa y la sanción que se le deriva.

${ }^{141}$ Por analogía a lo previsto en el Código Penal, dejando fuera los supuestos de autoría material, el perímetro donde encontrar a esos responsables -por su participación en la infracción- debería quedar limitado a supuestos de inducción; a los de cooperación necesaria,

(C) UNED. Revista de Derecho UNED, núm. 17, 2015 
los responsables tributarios de las infracciones tributarias responden económicamente ${ }^{142}$, junto al sujeto infractor -legalmente establecido- de las mismas, de las sanciones correspondientes, siempre que concurran los requisitos de culpabilidad exigidos por la STC 76/1990, de 26 de abril. Sin embargo, lo que los preceptos $182.1^{143}$ y 181.3 de la LGT regulan, como se ha dicho, es la solidaridad en el pago ${ }^{144}$ de la sanción, lo cual no obsta, lógicamente, a que en cualquier caso la Administración pueda incoar el expediente sancionador frente a todos los presuntos infractores, donde quede convenientemente demostrada la culpabilidad de cada uno de ellos en la comisión ${ }^{145} \mathrm{de}$

o sea, la cooperación a la ejecución con un acto sin el cuál no se habría ejecutado y, según algunos autores, a los de simple complicidad -consistente en la participación de una persona con un hecho que, sin ser imprescindible, lo facilita-y a los de encubrimiento.

${ }^{142}$ En estos casos se está ejerciendo una acción sancionadora frente al responsable y a ella queda subordinada la acción de responsabilidad y por supuesto la acción de derivación de la obligación de pago. Este es el criterio sostenido, de forma implícita, en la Sentencia del Tribunal Supremo de 10 de diciembre de 2008 y en las SSTSJ de Madrid de 15 de julio de 2010 y de 8 de febrero de 2011.

${ }^{143}$ MARTÍNEZ LAGO considera que con ese proceder se contradice el principio de personalidad de la sanción. La razón de ello se encuentra, como ya se mencionó en relación al aseguramiento del pago de las multas que determina el art. 31.2 CP para supuestos de actuación en lugar de otro, en que se deja de considerar a las sanciones pecuniarias como lo que en realidad son un castigo, penal si es aplicado por los jueces, y administrativo si corresponde a órganos de la Administración pública su aplicación. MARTÍNEZ LAGO, M. A. (2008), pág. 160.

${ }^{144}$ Caso de una infracción tributaria cometida por un solo obligado tributario-sujeto infractor, pero en cuya comisión hubieran participado otra u otras personas, en este caso existe un solo sujeto infractor, una sola infracción, una sola sanción y varios obligados al pago de la misma, uno como deudor principal (sujeto infractor) y otro/os como responsable/s tributario/s. DÍEZ OCHOA, J. M. (2006), pág. 69; Resulta contradictorio con la naturaleza de la institución tutelar el interés de cobro de la Administración mediante la extensión de la responsabilidad pecuniaria sobre el patrimonio de terceros. Si el responsable tributario comete un ilícito, lo que debe hacerse es imponérsele una sanción autónoma, cuyo pago no libere al infractor principal. Es absurdo y contrario al principio de personalidad de la sanción, que el responsable tenga que pagar una sanción impuesta a otro y que éste libere de su personal responsabilidad mediante el pago realizado por el responsable. SIMÓN ACOSTA, E. (2004), pág. 715; debe reputarse constitucional la regulación contenida en la LGT 58/2003, que opta por extender la responsabilidad a las sanciones en todos los supuestos en que ésta deriva de la colaboración del responsable en un ilícito. En todo caso, BLÁZQUEZ LIDOY hace notar que el haber colaborado en una infracción, si la ley no lo dispone expresamente, no alcanzará a las sanciones. MARTÍNEZ MICÓ, J. G.(2009); GALAPERO FLORES, R.(2010): «Responsabilidad tributaria subsidiaria por sucesión en la empresa. Comentario a la Sentencia de la Audiencia Nacional de 7 diciembre 2009», QF, núm. 8.

${ }^{145}$ En relación a los supuestos del art. 42.2 LGT, desde el punto de vista del principio de personalidad de la pena -aplicable en el ámbito tributario sancionador según una inveterada doctrina constitucional-, resulta criticable que el responsable asuma el pago de la sanción impuesta al obligado principal y en cuya generación aquél no ha participado en modo alguno, dado que, normalmente, en el momento en que se realiza el presupuesto de hecho de la responsabilidad, la infracción ya habrá sido cometida. En consecuencia, estimamos que el importe de las sanciones debería excluirse del alcance de la responsabilidad, imponiendo al responsable una sanción autónoma en el 
los hechos que fundamenten la imposición de la sanción ${ }^{146}$. El supuesto del artículo 182.1 de la LGT $^{147}$, no es equiparable a la pluralidad [solidaridad] de infractores que prevé el artículo 181.3, porque aquí todos los sujetos son titulares de una misma infracción, todos han realizado la acción u omisión tipificada en cualidad de coautores, siéndoles exigible a cualquiera el importe

caso de que su conducta fuera merecedora de castigo. «ni el carácter ilícito de un comportamiento justifica la obligación de pagar la sanción impuesta a otra persona por una conducta distinta, ni quien impide la ejecución forzosa del importe correspondiente a una sanción tributaria está causando a la Administración un daño patrimonial que pueda ser obligado a compensar o indemnizar». DE MIGUEL ARIAS, S. (2009): «La responsabilidad tributaria por conductas que impiden o dificultan el embargo o la ejecución de los bienes del obligado tributario», $Q F$, núm. 14; sin embargo, la figura del responsable regulada en el apartado segundo del artículo 42 de la LGT presenta ciertos caracteres que la diferencian del resto de las hipótesis de responsabilidad, lo cual influye, sin duda, en su regulación jurídica. A este respecto, y dada su primigenia ubicación en un artículo separado, en ocasiones se consideró que este supuesto concreto no constituía un verdadero caso de responsabilidad ( Resolución del TEAC de 18 de diciembre de 2003). En este sentido, se ha venido entendiendo que dicho supuesto encuentra su fundamento en la responsabilidad extracontractual por actos u omisiones lesivos realizados por persona ajena a una relación crediticia (art. 1902 Código Civil) de hecho, el que la responsabilidad se limite en este caso al valor de ciertos bienes, demuestra que la norma no ha pretendido simplemente garantizar la deuda tributaria, sino que, más bien, obliga a indemnizar los daños y perjuicios a quien ha causado un daño patrimonial. Si bien es cierto que el responsable no guarda relación alguna con la generación de la deuda tributaria que pretende cobrarse, en estos supuestos, aquél se encuentra obligado ante la Administración tributaria por el daño derivado de su conducta contraria al procedimiento de recaudación ejecutiva 9. ZABALA RODRÍGUEZ- FORNOS, A., «Artículos 35 a 48 de la LGT», en HERRERO DE EGAÑA Y ESPINOSA DE LOS MONTEROS, J. M. (coord.) (2008), págs. 359 a 361; En esta línea, resulta patente que el artículo 42.2 de la LGT presenta un claro componente infractor que hubiera permitido establecer infracciones tributarias autónomas, si bien, siguiendo la tradición normativa, el legislador ha configurado un supuesto de responsabilidad. MARTÍNEZ LAGO, M.Á.: La extensión de la responsabilidad a las sanciones tributarias, Tirant lo Blanch, Valencia, 2008, págs. 257 a 267; también CALVO ORTEGA, R., «Obligados tributarios», en CALVO ORTEGA, R. (2004), pág. 178; El plazo de prescripción de la obligación de pago para los responsables solidarios del art. 42.2 LGT se computará conforme al art. 67.2.2 LGT. Exponiendo el dies a quo más detalladamente, RODRÍGUEZ MÁRQUEZ, J.(2004): «La prescripción de la obligación del responsable en la nueva LGT», Nueva Fiscalidad, núm. 4, pág. 51.

${ }^{146}$ De hecho, en opinión de ALMENAR BELENGUER y RIPLEY SORIA, la iniciación formal del procedimiento sancionador contra uno de los sujetos infractores sólo interrumpirá la prescripción de la acción para sancionar respecto de dicho sujeto, frente a la regla general del artículo 68.7 LGT, conforme al cual «interrumpido el plazo de prescripción para un obligado tributario, dicho efecto se extiende a todos los demás obligados...». En «La potestad sancionadora», SIMÓN ACOSTA, E.(2004), págs. 1290 y 1291.

${ }^{147}$ Cuando una persona es causante o colaborador en una infracción, si ésta supone un daño o perjuicio sobre créditos tributarios, de los que no es sujeto pasivo, se impone además, como responsabilidad diferenciada de la que tiene naturaleza materialmente sancionador o represiva, y aunque derive de ésta última, la obligación de responder de los créditos tributarios perjudicados como consecuencia de la citada infracción. MARTÍNEZ LAGO, M. A.(2008), pág. 176. 
total de la multa ${ }^{148}$. En cambio, en los supuestos del art. 182.1, y en concreto los del artículo 42.1 y 42.2 de la LGT, no todos los intervinientes ${ }^{149}$ lo hacen

${ }^{148}$ Lo que verdaderamente ocurre es que se está tutelando el crédito de la Administración, confundiéndose de modo estrepitoso la culpa y la personalidad: Si el responsable ha realizado un ilícito y es culpable debe ser castigado con una sanción autónoma; sin embargo, con el sistema legal queda impune si el infractor paga. Si, por el contrario, su conducta no se tipifica o no es culpable, no se le debe sancionar. Lo que no encaja con la naturaleza de la sanción, es que se sitúe por encima de todo el derecho de cobro de la Administración y, una vez satisfecho éste, se despreocupe el legislador de distribuir entre los infractores el castigo. SIMÓN ACOSTA, E. (2004), pág. 718.

${ }^{149}$ HERRERA FERNÁNDEZ, ya en 1998, explicitaba -en relación al contenido del que hoy sería el actual art. 43.1.a LGT 2003, anterior 40.1.1. ${ }^{\circ}$ LGT 1963- que, conviene resultar que la derivación de responsabilidad no se exigirá al administrador que hubiere en el momento de la firma de las actas, o en el de la notificación de la providencia de apremio, sino que se dirigirá contra aquel que haya realizado el presupuesto de hecho previsto en la norma, es decir, el administrador que incurriendo en alguna de las conductas tipificadas en la misma haya provocado la infracción tributaria de la entidad que representa. el tema se complica. En principio, la responsabilidad debe atribuirse al administrador vigente durante los plazos reglamentarios, fijados en los distintos tributos, para el cumplimiento de las obligaciones tributarias impuestas dado que es en este periodo cuando se consuman las conductas infractoras tipificadas en la citada norma.

Sin embargo, en la realidad son numerosas las dudas que pueden plantearse partiendo de esta idea y a menudo se presentan situaciones problemáticas, tal y como sucede, por ejemplo, cuando tiene lugar un cambio de administrador durante el tiempo que media entre el devengo del tributo y el período reglamentariamente establecido para su declaración. En tal caso habrá que determinar donde tiene su origen la conducta infractora, si en la confección de los registros contables o fiscales que sirven de base a la declaración, en cuyo caso será responsable el administrador vigente cuando se devengó el impuesto, o en la propia elaboración de la declaración, en cuyo caso lo será el administrador vigente en el momento de su presentación.

Otras veces el cambio de administrador se produce dentro del período impositivo, en este supuesto el responsable a priori sería el nuevo administrador salvo que los hechos constitutivos de 1a infracción fueran imputables al anterior y desconocidos por este.

En definitiva, como puede apreciarse la casuística es muy amplia y los ejemplos mencionados no constituyen más que una breve reseña, por lo que en estos casos habrá que analizar detenidamente las acciones u omisiones que constituyen la conducta infractora y dar trámite de audiencia, dentro del procedimiento de derivación de responsabilidad, a todos los administradores implicados.

Asimismo vamos también a comentar una serie de situaciones problemáticas que se plantean con relativa frecuencia en la realidad cotidiana, como son la existencia de administradores con nombramiento no inscrito en el Registro Mercantil, o caducado, e incluso la situación a que se ven sometidas ciertas personas que desconocían por completo su condición de administradores de la sociedad en cuestión cuando fueron requeridos.

En relación con la primera de las situaciones apuntadas hay que recordar que el nombramiento de los administradores ha de ser objeto de inscripción obligatoria en el Registro Mercantil (arts. 125 de] T. R. L. S. A. y 58 de la L. S. R. L.), y que en virtud del principio de legitimación registral recogido en el artículo 7 del Reglamento del Registro Mercantil los asientos del Registro se consideran exactos v válidos y bajo la salvaguarda de los tribunales, mientras que estos no declaren lo contrario y sea inscrita la resolución judicial de la inexactitud o nulidad de los mismos.

Igualmente tanto el artículo 21.1 del Código de Comercio como el artículo 9.1 del R. R. M., establecen que los actos sujetos a inscripción sólo serán oponibles a terceros de 
buena fe desde su publicación en el BORME, por lo que a sensu contrario hay que interpretar que lo no inscrito no les puede perjudicar.

Por todo ello podemos concluir en principio, que siempre que en el expediente administrativo se encuentre suficientemente acreditado, de acuerdo con la información contenida en el Registro Mercantil, que el interesado ostentaba la condición de administrador en el momento de cometerse las infracciones tributarias por la sociedad, la protección que la publicidad registral ofrece a los terceros de buena fe, en nuestro caso 1a Hacienda Pública, hará muy difícil que prosperen las alegaciones que en sentido contrario puedan plantear los interesados.

Sin embargo, en alguna ocasión en el transcurso del procedimiento, se ha acreditado mediante documento público que no ha tenido acceso al Registro Mercantil, el cese del administrador requerido y el nombramiento de otras personas que desempeñaron el citado cargo. Pues bien, ante situaciones como la descrita, hemos de tener en cuenta que el principio de legitimidad registral opera como una presunción iurus tantum y por consiguiente admite prueba en contrario (que en el presente caso consiste en la simple presentación en el Registro del documento no inscrito) y que el nombramiento de administrador surte efectos desde su aceptación y no desde su inscripción, que no tiene carácter constitutivo.

También en alguna ocasión se ha planteado la procedencia de la derivación de responsabilidad a los administradores que al tiempo de cometerse las infracciones tributarias por la sociedad tenían un nombramiento caducado.

En principio tal y como señala el artículo 126 del T. R. L. S. A.: «Los administradores ejercerán su cargo durante el plazo que señalen los estatutos sociales, el cual no podrá exceder de cinco años. Podrán ser reelegidos una o más veces por período de igual duración máxima».

Sin embargo razones de estabilidad y permanencia del órgano de administración impiden que el mero transcurso del plazo determine, automáticamente, el cese de los administradores afectados. Por ello cuando caduca su nombramiento, sin perjuicio de incurrir en causa de disolución de la sociedad por la paralización de sus órganos sociales (art. 260 del T. R. L. S. A.), se produce una prórroga tácita o reelección de hecho que asegura la continuidad del funcionamiento interno de la sociedad, si bien la competencia del órgano de administración queda limitada a convocar una junta para que acuerde su reelección o sustitución, o bien solicitar del juez la convocatoria de dicha junta.

En consecuencia, y sin perjuicio de las responsabilidades que en el orden mercantil pudieran contraer, la circunstancia de tener el nombramiento caducado no debe ser obstáculo para que el administrador pueda ser declarado responsable subsidiario de las deudas tributarias impagadas por la sociedad, si se dan los requisitos que la normativa tributaria señala.

Para concluir este breve repaso a las situaciones conflictivas que se presentan en la práctica, resta por analizar la de aquellas personas que desconocían que su nombramiento estaba inscrito en el Registro Mercantil como administradores de la sociedad cuyas deudas impagadas se le reclaman.

Esta situación puede originar un posible comportamiento delictivo que la Hacienda Pública, evidentemente, no puede entrar a valorar, correspondiendo al interesado plantear las acciones judiciales que resulten procedentes. Con todo ante estas situaciones la Hacienda Pública debe actuar con extrema prudencia, adoptando las medidas cautelares que resulten necesarias para asegurar el cobro de la deuda tributaria perseguida y absteniéndose de continuar el procedimiento en tanto no se resuelvan las acciones judiciales emprendidas por el afectado

Por otra parte, de acuerdo con la normativa mercantil, la figura del administrador puede ser un órgano unipersonal, o lo que es más usual, estar integrado por una pluralidad de persona constituyendo un Consejo de Administración (art. 136 T. R. L. S. A.). 
con el mismo título, ni cualidad ${ }^{150}$, pues lo que sucede es que a un deudor principal, como puede ser el sujeto infractor [autor principal] se une, para que el cobro de la sanción y de la deuda tengan mayores garantías de éxito, otro sujeto [responsable tributario en el pago de la sanción] que ha causado o colaborado activamente con aquél en la realización de la infracción. En suma, se puede defender la existencia de dos clases de solidaridad en la obligación de pago de las sanciones tributarias, la solidaridad entre sujetos infractores principales ${ }^{151}$, y la solidaridad entre el sujeto infractor y el responsable económico de la sanción ${ }^{152}$, modalidad ésta en la que uno y

Se plantea entonces la cuestión de si la derivación de responsabilidad se ha de dirigir contra el presidente y consejeros delegados que pudieran existir, o si deben hacerse extensiva a todos los miembros del Consejo de administración. Esta segunda opción es la que se desprende a tenor de lo dispuesto en el artículo 133.2 del T. R. L. S. A. en el que se establece que «responderán solidariamente todos los miembros del órgano de administración que realizó el acto o adoptó el acuerdo lesivo menos Los que prueben que no habiendo intervenido en su adopción y ejecución desconocían de su existencia o conociéndola hicieron todo lo conveniente para evitar el daño o al menos se opusieron expresamente a aquél» y en el que, como se observa, se recogen también una excepción similar a la prevista en el artículo 77.4.c) de la L. G. T.. En definitiva, la única eximente a la responsabilidad consiste en faltar a la Junta en la que se aprobaron las cuentas o en oponerse a su aprobación.

Por último hay que recordar, como señala el artículo 37.6 de la L. G. T., que «Cuando sean dos más los responsables solidarios o subsidiarios de una misma deuda. esta podrá exigirse íntegramente a cualquiera dé ellos». Lo que supone que cuando existan varios administradores responsables, la Hacienda pública puede dirigir la acción de cobro contra cada uno de los simultáneamente.

${ }^{150}$ De la STC 76/1990, de 26 de abril, resulta suficiente probar que quienes han participado en la comisión de una infracción han mostrado una actitud equiparable a la simple negligencia. Si la ejecución de la infracción por el sujeto principal, el autor, no precisa-aunque pueda darse- de una forma más grave de culpabilidad, bastará el mismo grado de negligencia, aunque pueda darse dolo, para imputar al partícipe y extender al mismo la responsabilidad de la sanción. Resultaría más correcto que la participación sancionable, sólo fuese la de carácter doloso y no imprudente, pues la sanción de la participación debe requerir que la voluntad del partícipe se dirija a contribuir activamente en la realización del hecho principal. MARTİNEZ LAGO, M. A.(2008), pág. 193.

${ }^{151}$ HERRERO MADARIAGA ha sostenido que no es admisible entender que la responsabilidad solidaria es predicable respecto de las sanciones, pero sí de la obligación tributaria, pues en relación a aquéllas lo que existiría es un supuesto de titularidad en la comisión de una infracción que deriva en la cotitularidad en la obligación pecuniaria en que se traduce la sanción. De esta manera, los partícipes en la infracción ajenos a la realización del hecho imponible, son responsables solidarios respecto de la obligación tributaria, pero obligados principales o titulares solidarios de respecto de la sanción. Citado por MARTÍNEZ LAGO, M. A.(2008), pág. 174.

${ }^{152}$ Las sanciones tributarias, como especie correspondiente al genero de las sanciones administrativas, son equiparables en su estructura y finalidad a las penas impuestas por la comisión de un delito, lo que las convierte en prestaciones de naturaleza personalísima; nadie más que el sujeto sancionado puede ser obligado a pagarlas. Imponer una sanción tributaria a una persona determinada y, después, obligar a otra distinta al pago de la misma, supone una flagrante vulneración de los principios informadores del Derecho administrativo sancionador, particularmente el principio de culpabilidad. Por su 
otro no están obligados del mismo modo, por los mismos plazos y por las mismas condiciones, al igual que la solidaridad entre el deudor principal y el fiador solidario. Ello permite dar respuesta a la pregunta ${ }^{153}$ ¿qué sucede

misma naturaleza, el pago de las sanciones tributarias no puede ser garantizado personalmente por un tercero. Por esa misma razón, cuando el infractor no realiza el pago de la sanción o se retrasa en el mismo, la Administración no sufre daño patrimonial alguno, por el cual tenga derecho a ser indemnizada; tan sólo queda un ilícito sin sancionar. Por tanto, no es posible obligar al responsable tributario a pagar las sanciones tributarias ajenas o, lo que es lo mismo, nadie podrá ser obligado a pagar una sanción tributaria a título de responsable tributario. La persona designada como responsable tributario puede ser sancionada por la realización culpable de una acción antijurídica tipificada por la Ley, y concretamente, por el incumplimiento de la obligación de pagar la deuda tributaria ajena. Incluso podría pensarse en la posibilidad, admitida por el Tribunal Constitucional en la Sentencia 96/1990, de que la persona designada como responsable tributario y el sujeto pasivo o deudor principal fueran sancionados solidariamente por la realización conjunta de una infracción tributaria. Lo que no es posible es obligar a pagar una sanción tributaria en cuanto responsable tributario, esto es, en cuanto persona obligada a pagar la deuda tributaria ajena. GONZÁLEZ ORTIZ, D.(2003): La figura..., págs. 7380. Resulta inadmisible que el Estado tenga derecho a ser indemnizado por el incumplimiento de la obligación de pago de una sanción, puesto que aquél no busca el lucro con su imposición, ni la reparación de un daño patrimonial, sino la prevención a través de la represión. La sanción solamente se puede exigir como forma de sancionar la realización de una conducta antijurídica y culpable, nunca como garantía personal del pago de la sanción impuesta a otra persona, o para indemnizar al Estado por la colaboración en la lesión del derecho de crédito del Estado a la percepción del importe de la sanción. Los fines perseguidos a través de la imposición de una sanción, que son los que justifican el ejercicio de la potestad sancionadora, solamente se consiguen imponiendo la responsabilidad sobre la sanción a quienes han realizado de manera culpable los hechos tipificados como infracción, pero nunca obligando a un tercero a responder de la misma. Aceptando que una persona solamente puede ser obligada a pagar una sanción en concepto de infractor, por haber realizado de forma culpable una acción u omisión antijurídica tipificada por la ley, y no a título de obligado al pago de la deuda tributaria ajena, un importante sector doctrinal defiende la posibilidad de que la responsabilidad tributaria se extienda a las sanciones, siempre que el responsable tributario hubiera participado en la realización de la acción material tipificada como infracción tributaria. En opinión de este sector de la doctrina (PÉREZ ROYO, DE LA HUCHA CELADOR, PALAO TABOADA), cuando el presupuesto de hecho de la responsabilidad tributaria se encuentra configurado por la participación del responsable en la comisión de una infracción tributaria, en relación con la sanción impuesta al deudor principal, no estaríamos ante una obligación de pago de la sanción ajena. Solamente existiría responsabilidad tributaria en sentido técnico respecto de la deuda tributaria propiamente dicha, pero no podría decirse que la responsabilidad tributaria se extiende a las sanciones. Es decir, mientras que en relación con los demás elementos de la deuda tributaria, el responsable tributario vendría obligado a pagar en concepto de responsable tributario; por el contrario, el responsable tributario sería cotitular de la sanción tributaria. Habría una realización conjunta de la infracción tributaria que, por disposición del mismo precepto que ordena la responsabilidad tributaria, derivaría en la cotitularidad solidaria pasiva de la obligación pecuniaria en que se traduce la sanción. Habría una responsabilidad tributaria sobre la deuda tributaria propiamente dicha, y una cotitularidad principal de la sanción.

${ }^{153}$ Ibíd.., págs. 373 a 376; También los responsables, a quienes hipotéticamente puede extenderse una sanción...deberían de resultar llamados al procedimiento sancionador tributario, puesto que pueden considerarse interesados en el desarrollo y conclusión del

(C) UNED. Revista de Derecho UNED, núm. 17, 2015 
cuando en la realización de un mismo hecho infractor han participado una pluralidad de sujetos? Dependerá de que todos lo hayan ejecutado en grado de autores (supuesto del artículo 181.3 de la LGT), siendo entonces cotitulares del mismo presupuesto de hecho infractor y merecedores, por tanto, de idéntica sanción si su culpabilidad es la misma; o resulte que algunos intervinientes hayan tenido una participación menor aunque necesaria en la comisión de la infracción, v.gr. por colaboración activa ex artículo 42.1.a) de la LGT, pero sin alcanzar la cualidad de coautores, sin encontrarse su comportamiento suficiente y autónomamente tipificado por la ley. Sólo en el primer caso tendremos varios autores de una misma infracción, un solo procedimiento sancionador, seguido respecto de todos ellos y, llegado el caso, una única sanción de cuyo pago deberán responder solidariamente todos los sujetos infractores, de conformidad con lo dispuesto en el artículo 181.3 de la LGT. En caso de que uno o más cotitulares de la pretendida infracción discrepen respecto de otro sobre su grado de culpabilidad, si la Administración efectivamente aprecia que hay una diferencia de culpa entre quienes concurrieron en la infracción, podrá resolver que no se ha consumado el tipo de que se trate por todos los presuntos sujetos infractores ya que, a diferencia del proceso penal, el procedimiento sancionador en materia tributaria no se podrá dirigir a la determinación del grado de participación, pues esa distinción es ajena a la LGT, sino que sólo podrá dirigirse a probar la realización-como autor principal-del tipo infractor, y si en los hipotéticos cotitulares no concurriese el mismo grado de culpabilidad, no podrá considerarse que todos han realizado un único tipo, pero tampoco se podrá imponer sanciones diferentes a cada uno de ellos, pues sólo es posible la imposición de una sanción.

Por otro lado, en cuanto al cómputo del plazo de prescripción ${ }^{154}$ de la responsabilidad del responsable solidario o subsidiario hay que estar a lo

mismo. ORÓN MORATAL, G. et alii (2006): Nuevo régimen jurídico de los procedimientos tributarios. El procedimiento sancionador. Estudios de Derecho Judicial, Ed. Consejo General del Poder Judicial, Madrid, pág. 43.

${ }^{154}$ No obstante, conviene traer a colación la referida Sentencia de 7 de julio de 2010 (cit.), por cuanto resuelve gran parte de las cuestiones aquí formuladas, reproduciéndose seguidamente, por razones de unidad de doctrina, lo resuelto en aquélla:... Por otra parte, tratándose de un acto de derivación de responsabilidad en el ámbito tributario, como declaró el Tribunal Constitucional, en la sentencia 85/2006, de 27 de marzo, debe darse a los administradores la posibilidad de manifestar lo que estimen conveniente acerca de, al menos, las siguientes cuestiones: en primer lugar, sobre si efectivamente la persona jurídica cometió las infracciones tributarias por las que fue sancionada, esto es, en el caso enjuiciado, si dejó de ingresar la cuota y, en el supuesto de que así fuese, si las omisiones se produjeron culpablemente o, por el contrario, concurría alguna causa de exclusión de la responsabilidad; en segundo lugar, en caso de que la entidad hubiera cometido la infracción tributaria, sobre cuáles son las sanciones que correspondía imponer por los ilícitos cometidos y, en tercer lugar, sobre la pertinencia de la derivación de responsabilidad acordada. El artículo 37 de la antigua Ley General Tributaria establecía que desde la no- 
dispuesto en los artículos 66.b), 67 y 68 LGT. De esos artículos adveramos que si bien prescribirá, entre otros a los cuatro años el derecho de la Administración para exigir el pago de las deudas tributarias liquidadas y autoliquidadas -por remisión del art. 190.2 LGT-[66.b LGT], también el plazo de prescripción comenzará a contarse desde el día siguiente a aquel en que finalice el plazo de pago en período voluntario, sin perjuicio de que el plazo de prescripción para exigir la obligación de pago a los responsables solidarios comenzará a contarse desde el día siguiente a la finalización del plazo de pago en periodo voluntario del deudor principal. No obstante, en el caso de que los hechos que constituyan el presupuesto de la responsabilidad se produzcan con posterioridad al plazo fijado en el párrafo anterior, dicho plazo de prescripción se iniciará a partir del momento en que tales hechos hubieran tenido lugar. Tratándose de responsables subsidiarios, el plazo de prescripción comenzará a computarse desde la notificación de la última actuación recaudatoria practicada al deudor principal o a cualquiera de los responsables solidarios. Conforme ha indicado la jurisprudencia ${ }^{155}$, cuestión distinta es la aplicación del régimen de prescripción de las sanciones respecto de los responsables subsidiarios, que igualmente es abordada en la Sentencia del Tribunal Supremo, de 17 de marzo de 2008 (recurso de casación nú-

tificación del acto de derivación de responsabilidad se conferirán a los responsables «todos los derechos del deudor principal», y el art. 174.6 de la Ley 58/2003, de 17 de diciembre, dispone ahora que en el recurso o reclamación contra el acuerdo de declaración de responsabilidad «podrá impugnarse el presupuesto de hecho habilitante y las liquidaciones a que alcanzan dicho presupuesto», pudiendo como consecuencia de la resolución de dichos recursos o reclamaciones revisarse «el importe de la obligación del responsable»... Existen, pues, dos periodos diferentes: el que se refiere a la prescripción de las acciones frente al deudor principal, que abarca todo el tiempo que transcurra hasta la notificación de la derivación de responsabilidad, y el que se abre con tal acto, siempre que la prescripción no se hubiese producido con anterioridad, que afecta a las acciones a ejercitar contra el responsable subsidiario, teniendo incidencia dentro de cada uno de dichos periodos las actuaciones con capacidad para interrumpir el correspondiente plazo de prescripción con arreglo a lo dispuesto en el artículo 66 de la Ley General Tributaria de 1963. La Ley General Tributaria que se encuentra en vigor en la actualidad [ Ley 58/2003, de 17 de diciembre (BOE de 18 de diciembre)] aclara toda duda sobre el particular, ya que en el artículo 67.2, último párrafo, se refiere al cómputo del plazo de prescripción para los responsables subsidiarios indicando que empieza a contarse desde la notificación de la última actuación recaudatoria practicada al deudor principal o cualquiera de los deudores solidarios. Este precepto, por lo demás, no se opone al régimen imperante bajo la vigencia de la Ley de 1963, en el que, con arreglo al artículo 164 del Reglamento General de Recaudación, la declaración de fallido de los deudores principales y, en su caso, solidarios constituía el dies a quo para iniciar las actuaciones respecto de los subsidiarios. Teniendo en cuenta esta doctrina y al haber sido declarado fallido el deudor principal por acuerdo de la Dependencia de Recaudación de fecha 24 de septiembre de 1999, lo que determinó el inicio del procedimiento de derivación el 14 de octubre de 1999, acordándose esta última, tras el pertinente trámite de alegaciones, el 25 de mayo de 2000 , resulta evidente que la prescripción que se pretende no ha tenido lugar (STS 19.05.2014, FJ 2).

${ }^{155}$ Por todas la STS de 5.03.2013 (Rec. Cas.2839/2010).

(C) UNED. Revista de Derecho UNED, núm. 17, 2015 
mero 6738/2003) en cuyo Fundamento de Derecho Sexto se recoge lo que es doctrina jurisprudencial de esta Sala sobre la materia, al señalar el: «[p]lazo de prescripción con respecto a los responsables subsidiarios. La prescripción ha sido y es una forma de extinción de las obligaciones de los responsables tributarios, pero ha suscitado problemas la determinación de la fecha del inicio del cómputo del correspondiente plazo. Algún pronunciamiento de Tribunal Superior de Justicia (STJ de la Comunidad Valenciana de 15 de diciembre de $2000^{156}$ ) ha considerado que el cómputo del plazo de prescripción para el responsable se produce desde la misma fecha que respecto al deudor principal y no desde el acto de derivación de la responsabilidad. Pero esta tesis no puede ser acogida, pues si la acción para dirigirse frente al responsable es una acción recaudatoria, no existe razón alguna para considerar que la prescripción no se interrumpa por las actuaciones integrantes de la vía de apremio seguidas frente al deudor principal. Así, la tesis mayoritaria en los pronunciamientos jurisdiccionales es la que fija el comienzo el plazo de prescripción para el responsable en el acto de derivación de responsabilidad. Como ha señalado la Sala, STS de 17 de octubre de 2007, el plazo de prescripción respecto de la obligación del responsable ha de empezar a contar desde que se pueda ejercitar la acción contra él, en aplicación del

${ }^{156}$ Cuyo FJ 4, sin desperdicio alguno, expresó «[e]llo es así en cuanto que el criterio de esta Sala en cuanto a la prescripción de las deudas tributarias en las que se produce derivación de responsabilidad es el de que el término inicial de la prescripción para el responsable subsidiario es el mismo que el del deudor principal y no el del acto de derivación. Otra solución sería contraria no solo a la teoría general de la subrogación en la titularidad activa o pasiva de las obligaciones, sino también -en el estricto ámbito de las relaciones jurídico públicas- al principio de seguridad jurídica, pues resulta que el inicio del plazo prescriptorio respecto del responsable subsidiario no tendría ninguna referencia objetiva para su determinación apriorística al depender del momento en el que se declarasen fallidos los responsables directos (lo cual es de imposible predeterminación).

Por otra parte, no puede entenderse que la prescripción respecto del responsable subsidiario se interrumpe por las actuaciones realizadas o los recursos interpuestos por el responsable directo, pues tan solo pueden interrumpir la prescripción para cada responsable de distinto grado los actos notificados al mismo. Así lo señala inequívocamente la Sentencia de la Sala Tercera del Tribunal Supremo de 27 de diciembre de 1996, cuando afirma que: «De lo actuado en el expediente resulta que aunque en el año 1978, era sujeto pasivo de la Contribución Territorial Urbana, Inmobiliaria M., a la cual se notificó por edictos, por imposibilidad de hacerlo personalmente, la liquidación que da lugar a este proceso, sin que existiera acto administrativo de derivación de responsabilidad, intenta por la recaudación ejecutiva del Ayuntamiento de Valencia, el cobro de dicha liquidación a la Comunidad de propietarios constituida sobre el edificio construido por la indicada sociedad. La inexistencia de ese acto administrativo de derivación de responsabilidad sería suficiente para la anulación del procedimiento de apremio iniciado, pero como resulta que la Comunidad de Propietarios recurrente no tuvo formal conocimiento del mismo hasta el año 1984, es claro que entonces se había producido la prescripción del tributo, prescripción que no puede considerarse interrumpida por una notificación efectuada a una persona distinta». 
principio de la actio nata y no desde la fecha en la que se devenga originariamente la liquidación en la que se fija la obligación del sujeto pasivo. La prescripción del derecho de la Administración a exigir el pago de la deuda tributaria comienza a correr desde el día en que finaliza el plazo reglamentario establecido para el pago voluntario, tal como establecen los artículos 64 b ) y 65 de la LGT/1963, pero ha de entenderse referida al obligado principal, porque es el sujeto pasivo el primer obligado al pago; y si no estuviera prescrita la acción para él, debido a los actos interruptivos a los que se refiere el artículo 66 de la citada LGT/1963, resultaría absurdo entender que el plazo de prescripción seguía corriendo, al margen de dichas circunstancias, para los obligados secundarios. Existen pues, dos periodos diferentes: el que se refiere a la prescripción de las acciones frente al deudor principal, que abarca todo el tiempo que transcurra hasta la notificación de la derivación de responsabilidad, y el que se abre con tal acto, siempre que la prescripción no se hubiese producido con anterioridad, que afecta a las acciones a ejercitar contra el responsable, teniendo incidencia en el cómputo de los plazos prescriptorios, dentro de los indicados periodos, las actuaciones interruptivas a que se refiere el artículo 66 de la LGT/1963. Y en la actual LGT/2003 es el artículo 67.2, último párrafo, el que se refiere al cómputo del plazo de prescripción para los responsables subsidiarios, que empieza a contarse, precisamente, desde la notificación de la última actuación recaudatoria practicada al deudor principal o cualquiera ${ }^{157}$ de los deudores solidarios. Criterio que no supone diferencia sustancial con respecto al mantenido de acuerdo con las previsiones del régimen de la anterior LGT/1963, que consideraba dies a quo la actuación que producía la declaración ${ }^{158}$ de fallidos ${ }^{159}$ de deudores

${ }^{157}$... la declaración de falencia de los responsables solidarios se producirá en el supuesto en que se determine su existencia, se les identifique y se investigue que tienen bienes; solo una vez terminada la vía de apremio sin haber logrado encontrar bienes algunos de su propiedad, ni satisfechos lo importes de las deudas tributarias, se declararían fallidos. De lo actuado no consta que exista tal categoría de responsables solidarios y la parte recurrente no ha hecho prueba alguna encaminada a determinar quién o quienes pudieran tener tal condición de responsables solidarios, ni los nombra, ni demuestra que se hallen en una situación legal de responsabilidad solidaria. Ante tal falta de actividad probatoria de la parte, se comprende que la Administración recaudatoria no hubiera detectado la existencia de responsables solidarios (STS 10.01.2014, FJ 3).

${ }^{158}$ Literalmente, los preceptos transcritos (apartados $1 .^{\circ}$ y $3 .^{\circ}$ del art. $67.2 \mathrm{LGT}$ ), vienen referidos a la obligación de pago, es decir al ejercicio de la acción de derivación para exigir el pago al ya, antes, declarado responsable. Delgado González, A. F; Ragel Bonilla, A. J.: (2013): «La prescripción...», op. cit.

${ }^{159}$ En todo caso, hay que reconocer que no existe previsión normativa alguna que imponga la notificación al responsable subsidiario de la declaración de fallido. Así lo hemos declarado en la sentencia de 18 de octubre de 2010, cas. 2233/2006. (STS 30.10.2014, FJ 3). El expediente de derivación de responsabilidad se abre en vía recaudatoria tras la declaración de fallido del deudor principal, lo que impide aplicar a esta fase preceptos de la vía de gestión tributaria. Además, la institución de la caducidad

(C) UNED. Revista de Derecho UNED, núm. 17, 2015 
tiene su razón de ser en la previa fijación de un plazo, al que queda supeditada la actuación al que se refiere, en el que inicio y finalización de dicha actuación aparecen fatalmente unidas. La consecuencia jurídica de la inactividad durante dicho plazo es el decaimiento del derecho no accionado. En la materia que nos ocupa, expedientes de derivación de responsabilidad, la ley no fija un plazo de duración a dichas actuaciones; por lo que tan solo rige el plazo de prescripción que anteriormente ya se ha analizado» (STS 2.10.2014, FJ 2); Hemos de centrar la atención en el art. 55 de la LC, dedicado a regular las «ejecuciones y apremios» en el desarrollo de un concurso de acreedores y cuya redacción actual responde a las modificaciones introducidas como consecuencia de la entrada en vigor de la Ley 38/2011 (RCL 2011, 1847, 2133). SÁNCHEZ PINO, A. J.(2004): "La concurrencia del procedimiento de apremio con el procedimiento concursal», Quincena Fiscal, n. ${ }^{\circ}$ 8, 2004. la derivación de responsabilidad subsidiaria debe ir precedida de un procedimiento de apremio seguido frente al concursado con resultado de insolvencia o fallido, pero en virtud de la LC tal procedimiento no puede iniciarse declarado el concurso, bien es cierto que con alguna excepción. Ante las dudas que genera esta situación la solución propuesta por la doctrina no ha sido unánime. Así, se ha defendido que en estos casos no sería necesario iniciar un apremio frente al deudor principal, toda vez que la declaración de concurso es presupuesto suficiente para que se declare un crédito como fallido y, a su deudor, como insolvente, siendo procedente entonces la derivación de responsabilidad frente al administrador concursal cuando pueda constatarse el daño para la Hacienda Pública provocado por la conducta irregular de aquél. A nuestro juicio, esta posición es perfectamente defendible en algunos casos, bien es cierto que matizada, ya que no siempre que se abre un concurso ha de presuponerse que los créditos de los acreedores quedarán finalmente insatisfechos, debiendo esperarse en muchos casos a la finalización del mismo para saber si esa situación se producirá. Y es que ha de tenerse en cuenta que sin daño, traducido en la ausencia de cobro por parte de la Administración Tributaria, no hay responsabilidad, aun cuando pueda apreciarse alguna irregularidad en el quehacer del administrador concursal. Así pues, a nuestro entender, tal posición doctrinal podrá defenderse y aplicarse desde el momento en que puede constatarse la aludida conducta unida al perjuicio económico para la Hacienda pública, extremo que en algunos casos puede conocerse ya en fases previas a la finalización propiamente dicha del concurso. En estos casos consideramos que defender la puesta en marcha y finalización de un apremio frente al concursado no hará más que incrementar la cantidad adeudada por éste y retrasar, sin razón, la entrada del responsable en el ámbito de los obligados tributarios. En esa línea, GALÁN RUIZ, J.(2005): La responsabilidad tributaria, Thomson-Aranzadi, Navarra, pág. 185. En apoyo de la postura mencionada puede traerse a colación el tenor literal del artículo 61 del RGR, ya mencionado, en el que, si bien es cierto que se alude al crédito incobrable como aquél que no se ha hecho efectivo tras un procedimiento de apremio, también se hace referencia al concepto de deudor fallido, definición en este caso referida a «aquellos obligados al pago respecto de los cuales se ignore la existencia de bienes o derechos embargables o realizables para el cobro del crédito», esta fue, precisamente, la línea argumental seguida en Sentencias como la del TSJ de La Rioja, de 10 de marzo de 2009, en la que se consideró ya innecesaria la puesta en marcha de un procedimiento de apremio porque la insolvencia de la entidad, que en el caso enjuiciado se hallaba en suspensión de pagos, se desprendía con claridad del informe que en ese supuesto habían elaborado los interventores judiciales de la suspensión... Pues bien, la defensa de esa tesis por un sector doctrinal encuentra su contrapunto en la opinión sostenida por quienes entienden como imprescindible la puesta en marcha dicho procedimiento administrativo frente al concursado para que los responsables, en este caso administradores concursales, puedan recibir el acto administrativo en virtud del cual pasan a 
principales y, en su caso, solidarios conforme al artículo 164 RGR/1990». Pues bien, habrá que analizar caso a caso, si al iniciarse la acción de derivación de responsabilidad contra el recurrente se había producido ya la prescripción de la sanción respecto de la entidad o persona deudora principal, en cuyo caso también estará prescrita la del responsable ${ }^{160}$.

ocupar la posición de tales. Mantener esta postura implica, como ya se señaló, tener en cuenta lo dispuesto en el art. 55 de la LC, en virtud del cual, iniciado el concurso, la apertura de apremios tributarios únicamente podrá producirse con la finalización de tal situación, al menos por lo que respecta a los créditos calificados como concursales. Bien es cierto que, como excepción a lo previsto en ese precepto, del art. 84.4 LC (RCL 2003, 1748), modificado por la ley 38/2011, cabe deducir que respecto a los créditos contra la masa podrán iniciarse apremios cuando dichos créditos no se abonen a su vencimiento, llegando incluso a la fase de ejecución una vez aprobado el convenio, abierta la liquidación, o transcurrido un año desde la declaración de concurso sin que se hubieran producido ninguno de esos dos actos... así el TEAC en su Resolución de 9 de junio de 2010 en la que estima un recurso de alzada para la unificación de criterio concluyendo que procede «sentar el criterio de que la procedencia y conformidad a derecho de la declaración de fallido no depende de que se hayan cumplido todos los actos del procedimiento ejecutivo de apremio respecto de todas las deudas derivadas del sujeto pasivo, sino de que responda a la ausencia real de bienes o derechos realizables del deudor conocidos por la Administración tributaria»... En la misma línea algunos Tribunales Superiores de Justicia, como el de Galicia, en Sentencia de 30 de junio de 2011 considera que la declaración de fallido «lo que exige es el análisis previo de la existencia de bienes realizables en el patrimonio del deudor principal de suerte que solamente cuando éstos faltan entra en juego la eventual responsabilidad subsidiaria», ahora bien, entendiendo que «no es propiamente un título que abre la posibilidad de proceder contra el responsable subsidiario, al modo de un título ejecutivo, sino que es un presupuesto de hecho conforme al cual el procedimiento de derivación de responsabilidad es viable». Álvarez Barbeito, P (2013): «Aspectos ...», op. cit. En efecto, lo que se ha de tener en cuenta, a nuestro juicio, y a efectos de fijar el «dies a quo» del período de prescripción, no es la declaración de insolvencia del deudor, sujeto pasivo o de los responsables solidarios sino la misma insolvencia. De sostenerse lo contrario se dejaría en manos de la Administración el «dies a quo» del plazo de prescripción. Y ello estaría en oposición radical con el instituto de la prescripción porque vulneraría el principio de seguridad jurídica que es el que justifica el mismo. Y por último, como causas de interrupción han de considerarse las actuaciones de la Administración conducentes al ejercicio de la acción de responsabilidad con conocimiento formal del presunto responsable. DELGADO GONZÁLEZ, A. F; RAGEL BONILLA, A. J.: (2013): «La prescripción...» op. cit.

${ }^{160} \mathrm{El}$ «dies a quo» viene regulado en el artículo 671 bajo el principio de la «actio nata». Y las causas de interrupción vienen reguladas en los artículos 681 y 2 . Para que se produzca la interrupción de la prescripción por actuaciones administrativas se requiere el conocimiento formal de las mismas por parte de los obligados tributarios [Art. 682 a)]. Esta exigencia es consecuencia de uno de los principios básicos del derecho administrativo: la eficacia de los actos requiere de su notificación formal. Sin embargo, el artículo 68 8, infringiendo dicho principio, extiende los efectos de la interrupción frente a un obligado a los demás, de haber varios, y a los responsables, sean subsidiarios o solidarios. En relación con las sanciones tributarias, el artículo 189 de la Ley General Tributaria, establece el mismo plazo de prescripción. Como «dies a quo» establece el día en el que se cometieron las infracciones. Y como causas de interrupción se consideran las actuaciones de la Administración conducentes a la

(C) UNED. Revista de Derecho UNED, núm. 17, 2015 
Por último, esta regla de la solidaridad supone otra diferencia $^{161}$ fundamental con respecto al Derecho Penal, donde cada una de las personas que participan en la comisión del ilícito recibe la correspondiente pena, frente a la sanción única que se impone en el Derecho administrativo sancionador, y de la que se hace responder solidariamente a todos los sujetos infractores ${ }^{162}$, de suerte que el pago de la misma, por uno de ellos, tiene efectos liberatorios para el resto ${ }^{163}$.

imposición de la sanción, siempre que medie conocimiento formal de las mismas por parte del sujeto infractor. Delgado González, A. F; Ragel Bonilla, A. J.: (2013): «La prescripción...»op. cit. Por ello, consideramos que dichos preceptos son inconstitucionales por infringir el artículo 9 de la Constitución que, entre otros, constitucionaliza el principio de seguridad jurídica.

${ }^{161}$ Esta diferencia entre Derecho Tributario y Penal ha tenido fin con el que será art. 130.2 del CP, introducido por la LO 5/2010.

${ }^{162}$ En cualquier caso, la sanción pecuniaria es un castigo y no puede descuidarse ese aspecto ni siquiera cuando se procede a su recaudación, que debe estar plegada también a las garantías materiales y formales de los arts. 25 y $24 \mathrm{CE}$, como ha recordado la STC 85/2006, de 27 de marzo. MARTÍNEZ LAGO, M. A.(2008), págs. 160 y 161.

${ }^{163}$ ANEIROS opina que, en la medida en que es en el seno del procedimiento sancionador donde se acreditan tanto los hechos que constituyen infracción tributaria como los sujetos que los han realizado, la declaración de los partícipes en la comisión de una infracción debe efectuarse en el curso de la instrucción y especificarse en la resolución. Por ello, deben llamarse al procedimiento, puesto que, de alguna manera, pueden ser considerados interesados en el desarrollo y conclusión del mismo. ANEIROS PEREIRA, J. (2005), pág. 191. 